\title{
Climate change and the complex dynamics of green spruce aphid-spruce plantation interactions
}

\author{
John H. M. Thornley ${ }^{1}$, Jonathan A. Newman ${ }^{2, *}$ \\ 1 Centre for Nutrition Modelling, Department of Animal Biosciences, University of \\ Guelph, Guelph, Ontario, N1G 2W1, Canada. \\ 2 Department of Biology, Wilfrid Laurier University, Waterloo, Ontario, N2L 3C5, \\ Canada \\ * jonathannewman@wlu.ca
}

\begin{abstract}
Aphids can have a significant impact on the growth and commercial yield of spruce plantations. Here we develop a mechanistic deterministic mathematical model for the dynamics of the green spruce aphid (Elatobium abietum Walker) growing on Sitka spruce (Picea sitchensis (Bong.) Carr.). These grow in a northern British climate in managed plantations, with planting, thinning and a 60-year rotation. Aphid infestation rarely kills the tree but can reduce growth by up to $55 \%$. We used the Edinburgh Forest Model (efm) to simulate spruce tree growth. The aphid sub-model is described in detail in an appendix. The only environmental variable which impacts immediately on aphid dynamics is air temperature which varies diurnally and seasonally. The efm variables that are directly significant for the aphid are leaf area and phloem nitrogen and carbon. Aphid population predictions include dying out, annual, biennual and other complex patterns, including chaos. Predicted impacts on plantation yield of managed forests can be large and variable, as has been observed; they are also much affected by temperature, $\mathrm{CO}_{2}$ concentration and other climate variables. However increased $\mathrm{CO}_{2}$ concentration appears to ameliorate the severity of the effects of increasing temperatures coupled to worsening aphid infestations on plantation yield.
\end{abstract}

\section{Introduction}

The impact of climatic change on forests, pest populations, and their interactions, has been the focus of much work over the last several decades. The biology is complex, and involves both direct and indirect effects of multiple climate variables. Elevated $\mathrm{CO}_{2}$, changing temperature, and their interactions have direct impacts on plant growth and quality (from the herbivores' perspectives [1]). Many invertebrate pest species' population dynamics are highly sensitive to ambient temperature means and variances [2]. While a great deal of empirical experimental work has been done on species of economic consequence, their long-term responses to climatic change can only really be assessed with models. In this paper, we construct a mechanistic ecosystem simulation model of the interaction between Sitka spruce trees (Picea sitchenis) and their herbivores the green spruce aphid (Elatobium abietinum). 


\subsection{The biological system}

The green spruce aphid, E. abietinum (syn. Aphis abietina), is a significant pest of some species of spruce (Picea) in parts of Europe. Its ecology and impacts have been comprehensively reviewed by Day et al. [3]. Dixon [4] gives an excellent introduction to the science of aphids including much material relevant to the green spruce aphid. Sitka spruce (P. sitchenis) is an exotic species in northwest Europe; it is now the predominant plantation species in maritime areas, where it produces a yield of $9-15 \mathrm{~m}^{3}$ $\mathrm{ha}^{-1} \mathrm{y}^{-1}$ of stem wood over a rotation - in Scotland with Sitka spruce this is typically 60 years. It is one of the most productive trees in this situation and this is being enhanced by progressive genetic gains (see preface of [3]).

The aphid feeds on phloem sap [5]. It partially defoliates but rarely kills its host; it can depress annual growth by $10-50 \%$ [6]. The impact of such infestations is generally summarized by its effect on observed yield of stem wood during and over a rotation. A rotation length of 60 years does not allow studies which directly address the problem to be easily executed. Therefore research remains mostly empirical and short term. Randle and Ludlow ([7] p. 33) state that "The ideal model for defoliation studies remains to be developed" and this seems to remain largely true (but, for studies of aphids in other systems, see Table A.1 for summary).

Interest in this particular tree-aphid system's response to climatic change dates back to at least the mid-1990s. Straw [8] summarized the assessment at that time as follows (p. 134):

"Defoliation of Sitka and Norway spruce by the green spruce aphid

(Elatobium abietinum) is limited in the UK primarily by periods of cold weather which reduce the number of aphids overwintering. If winters become milder, as current models of climate change predict, then the aphid is likely to become more abundant and years with severe defoliation more frequent. In such circumstances the productivity of spruce will decline."

\subsection{Models of aphids and climatic change}

Probably due to their economic importance, aphids have been the focus of numerous modelling studies. These studies fall into three main types: statistical, agent-based, and mechanistic.

\subsubsection{Statistical models}

In the context of climatic change, statistical models of insect responses are largely so-called species distribution models (SDMs). Popular tools include Maxent (a form of presence only logistic regression modelling), Genetic Algorithm for Rule-set Production (GARP; [9]) and several others. For a comparsion of these techniques, see [10]. While these methods have been popular for modelling the potential impact of climatic change on non-aphid insects, they have rarely been used for aphids. There are plenty of examples of SDMs for aphids (see e.g. [11-13]) but it is more rare to see these coupled with projections of climatic change (but see e.g. $[14,15]$ ).

Statistical models contain no information beyond the original data used to construct them. They say nothing about the mechanisms that give rise to the response. For example, SDMs struggle to handle species interactions, due to their lack of mechanisms. This can be particularly problematic for herbivore-plant interactions since the host plant responds dynamically to climatic change and ignoring changes in the host plant's distribution or quality can result in very different views of the future (see e.g. $[16,17]$ ). Also, while it seems reasonable to estimate thermal tolerances from current species distributions, SDMs are incapable of considering changes in $\mathrm{CO}_{2}$ concentrations, 
another key component of climatic change for plant-herbivore interactions $[18,19]$. Nevertheless, statistical models are useful for summarizing data and interpolating between data. They are often 'user friendly' and can be readily fashioned into tools valuable to farmers or farm advisors.

\subsubsection{Agent based models}

Another common modelling approach is to use spacially explicit models (SEMs), particularly agent based models. DeAngelis et al. [20] provides a useful review of the approach and its relationship to other modelling approaches. They point out that SEMs can reveal aspects of local and regional level processes that are often absent in spatially implicit models (SIMs). Their review suggests that "spatial models in ecology have largely gone in different directions: towards SEMs for applied or pragmatic problems and towards SIMs for theoretical problems" ( [20] pg. 294). This is possibly due to the fact that SEMs require (or at least can make use of) detailed landscape information, the gathering of which can be a long, laborious, and expensive process [20]. Thierry et al. [21] develop a general agricultural landscape modelling framework that can be used to explore the effects of agricultural landscape dynamics on organisms. While agent-based modelling is used widely in ecology, its use for modelling aphid dynamics has been more limited.

Parry et al. [22] constructed an individual-based aphid population model. They modelled a $5 \mathrm{~km} \times 5 \mathrm{~km}$ region of Hertfordshire in southeastern England but did not consider climatic change. Agent based models are computationally intensive. As the authors point out, a challenge for this approach is to expand it so that it can cover realistic aphid densities across larger regions, which will increase the run-time and computational power required. Wiest et al. [23] simulated the population growth of the Rhopalosiphum padi in wheat plants exposed to environments with different thermal regimes. Population size varied according to the thermal regime. The effects of constant, daily variation, and outside mean minimum/maximum air temperature thermal regimes on the development and fecundity rates were not uniform. Although this model could be used to explicitly study the impacts of climate change, the authors did not do so. Picaza et al. [24] used an agent based model to study aphids as disease vectors, but did not model temperature dependent population growth and so it is not suitable for the study of climate change impacts.

\subsubsection{Mechanistic models}

There is a long tradition of using mechanistic models to study aphid population dynamics. Table A.1 summarizes a sampling of these models. Commonalities found in these models are readily apparent. First, with the exception of Newman et al. [25-29] these previous models have not been designed for, or used for, studying the impacts of climatic change (but see [30]). Second, since 'climate change' encompasses, at a minimum, changes in air temperature and $\mathrm{CO}_{2}$, none of the previous models are even suited to the task because they do not consider the effects of rising $\mathrm{CO}_{2}$ (again, with the exception of the Newman et al. studies). Third, with the exception of Barlow et al. [31-33] and a very basic model by Day et al. [3], none of previous models have considered tree aphids and even these models lack a mechanistic treatment of tree growth and physiology. And fourth, even for models that do include a consideration of the host plant, many of these models do not dynamically link the aphid and the host plant. That is, the models of the plants tend to be very simplified and unresponsive to aphid pressure. On the other hand, Newman et al. [25] constructed a model of cereal aphid population dynamics and coupled it to the Hurley Pasture Model [34,35], a long-established mechanistic ecosystem simulation model of temperate grass pastures. 
They [25] used this model to gain insight into the generality of aphid population dynamic responses to climatic change, to understand the magnitude and direction of each of the climate variables' impacts, and to explore the role of predation in controlling aphid populations under climate change $[25,27-29,36]$.

Our objective here is to construct a transparent mechanistic model of the green spruce aphid and interface this with a long-established mechanistic forest ecosystem simulation model, the Edinburgh Forest Model (efm, [37]). This is then used to examine predictions under various climate scenarios. We believe that an understanding of green spruce aphid dynamics can only be obtained by combining a mechanistic aphid model with a mechanistic plant growth model. No tuning (or less charitably - 'parameter twiddling') has been applied. At this stage, it is arguably more valuable to examine the range of behaviour the model can predict, than to look for an understanding of the discrepancies which may exist between observation and theory.

\section{Tree sub-model}

The aphid sub-model is interfaced with the Edinburgh Forest Model (efm). The efm is a mature and well-validated mechanistic simulator applicable to evergreen or deciduous forest ecosystems ([37]; see Appendix B below for the numerical methods employed). These can be grown as plantations, managed forests, or unmanaged forests. The model is based on simplified physiology and biochemistry with soil and water sub-models. The efm couples carbon $(\mathrm{C})$, nitrogen $(\mathrm{N})$ and water, fluxes and pools and provides stoichiometric balancing of the items represented. The efm is shown schematically in Fig 1 and sketched in some mathematical detail in Appendix C.

Fig 1. Tree sub-model of the Edinburgh Forest Model (efm). Aphids are connected to the tree sub-model on the left side in $\mathrm{A}$, where aphids extract $\mathrm{C}$ and $\mathrm{N}$ from the foliage (leaf, le) substrate pools, denoted $C_{\text {le }}$ and $N_{\text {le }}$, via the phloem [Eq (2)]. The aphid sub-model can be 'switched off' entirely (the default position). Go to figure.

\section{Overview of aphid sub-model}

In this section we give an overview of the aphid sub-model, which has ten state variables as shown in Fig 2. Details of the ordinary differential equations (ODE's) which determine their dynamics, the fluxes which contribute to the ODE's and their behaviour are given in detail in Appendix D.

Fig 2. The green spruce aphid sub-model. The ten state variables of the sub-model are shown in the boxes. There are four instars and an adult form for the wingless (apterous) and the winged (alate) aphids. Units for the state variables are number of aphids per stem (Appendix D). The differential equations for the state variables are Eqs (16), (47), (64) and (87). Go to figure. 


\section{Simulation scenarios}

\subsection{The environment}

To illustrate the model's dynamics, we used the average climate for Eskdalemuir, in northern Britain, latitude $55^{\circ} 19^{\prime} \mathrm{N}$, longitude $3^{\circ} 12^{\prime} \mathrm{W}$, altitude $242 \mathrm{~m}$ above sea level (Fig 3). The monthly data [38] were supplemented by monthly data from Clino [39]. Daily values were obtained by linear interpolation of monthly data (see chapter 7 and Section 7.5.3 of Thornley [34]). Daily data were applied to give diurnally changing data for air temperature (Fig 3A), relative humidity (Fig 3A), radiation (which is calculated from sunshine hours; Fig 3B), and wind (not shown). Soil temperature and rainfall were assumed constant over each day. The source program, efm.csl, gives details (see Appendix C).

Fig 3. Climate at Eskdalemuir. 30-year monthly means taken from meteorological tables are drawn. See text for details. Go to figure.

Wind speed at $50 \mathrm{~m}$ reference height $\left(h_{\text {ref }}\right)$ varies seasonally with the maxima of the daily maxima and daily minima occurring on 26 April. The mean and the variation of the daily maximum wind speeds are 6 and $1.5 \mathrm{~m} \mathrm{~s}^{-1}$. The mean and the variation of the daily minimum wind speeds are 2 and $0.5 \mathrm{~m} \mathrm{~s}^{-1}$. The mean annual wind speed is $1 / 2 \times(6+2)=4 \mathrm{~m} \mathrm{~s}^{-1}$. We assumed that the diurnal variation of wind speed is similar to that of air temperature $\left(T_{\text {air }}\right)$ and opposite to that of relative humidity $(\mathrm{RH})$ : the minimum wind speed (and minimum temperature and maximum $\mathrm{RH}$ ) occurs at dawn and the maximum wind speed (and maximum temperature and minimum $\mathrm{RH}$ ) at $15 \mathrm{~h}$.

Photosynthetically active radiation (PAR) varies from a minimum of 0.55 on 20 December to a maximum of 7.9 MJ PAR m $\mathrm{m}^{-2} \mathrm{~d}^{-1}$ on 15 June. It is calculated from bright sunshine hours (Fig 3B) by using a version of the Ångström formula ([34], pp. 145-146, equation 7.4i, but with $a_{\text {Ang }}=0.19$ and $\left.b_{\text {Ang }}=0.62 ;[40]\right)$ for daily PAR light receipt, $j_{\text {PARdy }}\left(\mathrm{J} \mathrm{m}^{-2} \mathrm{~d}^{-1}\right)$ from the fraction of bright sunshine hours which has been interpolated from monthly values (Fig 3B) to give daily values and refers to a given Julian day number.

Soil temperature was assumed to be diurnally constant and equal to mean daily air temperature; it varies from a minimum of $1.45^{\circ} \mathrm{C}$ on 16 January to a maximum of 13.5 ${ }^{\circ} \mathrm{C}$ on 16 July. Diurnal air temperature variation is a maximum of $5{ }^{\circ} \mathrm{C}$ on 16 May and a minimum of $2.15{ }^{\circ} \mathrm{C}$ on 16 December.

Relative humidity (RH) was assumed to be at its daily maximum at dawn and at its daily minimum at $15 \mathrm{~h}$. The $\mathrm{RH}$ daily maximum has a minimum of 0.75 on 16 May when the RH daily minimum is 0.65 and the $\mathrm{RH}$ daily minimum has a maximum of 0.88 on 16 December when the RH daily maximum is 0.91 .

Daily rain fall (assumed to be diurnally constant) is substantial, varying from a minimum of $2.8 \mathrm{~kg}(2.8 \mathrm{~mm}) \mathrm{m}^{-2} \mathrm{~d}^{-1}$ on 16 May, to a maximum of $5.65 \mathrm{~kg}(5.65 \mathrm{~mm})$ $\mathrm{m}^{-2} \mathrm{~d}^{-1}$ on 16 January, with an annual rain fall of $1527 \mathrm{~kg}(1527 \mathrm{~mm}) \mathrm{m}^{-2} \mathrm{y}^{-1}$ (see Fig $3 \mathrm{~A})$.

\subsection{Forest plantation}

A regime of planting to an initial stem density of $0.25 \mathrm{stems}^{-2}$ and an initial leaf area index of $0.003[\mathrm{Eq}(1)]$, followed by the removal of $0.45,0.4,0.35,0.3,0.25,0.2,0.15$ and 0.1 of the existing stems at times of $20,25,30,35,40,45,50$ and 55 years and terminated by clear felling at 60 years, was employed. Stem removal takes place at a
138

139

140

141

142

143

144

145

146

147

148

149

150

151

152

153

154

155

156

157

158

159

160

161

162

163

164

165

166

167 168 169 170

171 172 173 174 
constant rate over a period of $1 \mathrm{~d}$ ( 1 January normally) and this determines the thinning function $O_{\text {nstems,th }}$ of Eq (1), which depends on the integration step, maxt (Appendix B).

\subsection{Climate change simulations: temperature and $\mathrm{CO}_{2}$}

Various temperatures $\left(-3\right.$ to $\left.+4{ }^{\circ} \mathrm{C}\right)$ below and above the ambient Eskdalemuir temperatures and two $\mathrm{CO}_{2}$ concentrations: $350,700 \mu \mathrm{mol} \mathrm{mol}{ }^{-1}$ were applied. Although current ambient $\mathrm{CO}_{2}$ is now above $400 \mu \mathrm{mol} \mathrm{mol}^{-1}$, we chose $350 \mathrm{mmol} \mathrm{mol}^{-1}$ as "current ambient" to aide comparison with previous experimental and theoretical research. Initial values for all efm state variables were equilibrium with no aphids for the temperature and $\mathrm{CO}_{2}$ level applied. The equilibrium is a 60 -year repeating equilibrium; the same 60 -year rotation period is applied to all the temperature $\times \mathrm{CO}_{2}$ scenarios considered, although this would not usually give the optimum timber yield (yield class, $Y_{\mathrm{C}}$ ) for all cases.

\section{$5 \quad$ Results}

\subsection{Aphid population dynamics}

In Fig 4 the aphid population densities $\left(\rho_{\mathrm{aph}}\right)$ are plotted together, $700 \mathrm{vpm} \mathrm{CO}_{2}$ (red) overlaid on $350 \mathrm{vpm} \mathrm{CO}_{2}$ (black), for each incremental temperature change $(\Delta T)$ from -2 to $+3{ }^{\circ} \mathrm{C}$ for the full 60 year rotation. Also shown are the corresponding spectral densities ${ }^{1}$ calculated for the final 32 years of the rotation. Peaks in the spectral density plots indicate periodicity [41]. Fig 4 demonstrates qualitative differences in the population dynamics. At $-2{ }^{\circ} \mathrm{C}$, aphids more or less die out well before the 60 year rotation is complete (they are still present, but at vanishingly low densities), and the die out happens faster under $700 \mathrm{vpm} \mathrm{CO}_{2}$. At $-1{ }^{\circ} \mathrm{C}$, both $\mathrm{CO}_{2}$ conditions transition to essentially the same, reasonably stable, annual cycles of relatively low aphid densities $\left(\rho_{\text {aph }}\right)$, although they do so on different trajectories and the spectral density shows that there is additional underlying within year structure. At ambient temperature $(\Delta T=0)$, both $\mathrm{CO}_{2}$ conditions begin with annual cycles but diverge and transition to chaotic dynamics. The corresponding spectral densities have no obvious structure, indicative of (though not determinative of) chaos. At $+1{ }^{\circ} \mathrm{C}$, aphids transition from annual cycles to more complex periodicities. The spectral densities show that the periodicities are different and out of phase with each other. At $+2{ }^{\circ} \mathrm{C}$ we see a similar pattern, but with stronger signals of periodicity. Finally, at $+3{ }^{\circ} \mathrm{C}$ and $350 \mathrm{vpm} \mathrm{CO}_{2}$, aphids again show sustained 2-point cycles, while at $700 \mathrm{vpm} \mathrm{CO}_{2}$ the annual cycles are supplemented with complex within year dynamics.

Fig 4. Aphid density dynamics. Shown are the time series of aphid densities $\left(\rho_{\text {aph }}\right)$ for incremental increases in temperature from $-2{ }^{\circ} \mathrm{C}$ to $+3{ }^{\circ} \mathrm{C} .350 \mathrm{vpm} \mathrm{CO}_{2}$ is shown in black, and $700 \mathrm{vpm} \mathrm{CO}_{2}$ is shown in red. Notice the qualitative differences in population dynamics that emerge as temperture and $\mathrm{CO}_{2}$ change. Next to each time series is the respective spectral density (arbitrary units) calculated from the last 32 years of each time series; the frequency ( $x$-axis) has been re-scaled to display in years. Go to figure.

We can compare the dynamics depicted in Fig 4 to those seen in Fig 5. Here we plot the normalized trap captures of alate E. abietinum using data extracted from Day et

\footnotetext{
${ }^{1}$ see https://www.jmp.com/support/help/en/16.0/index.shtml\#page/jmp/statistical-details-forspectral-density.shtml
} 
al. [42]. We can see that this time series too contains periodic structure verging on chaos. The spectral decomposition has less structure than we see in our simulations. While we show the spectral decomposition for the same length of time (32 years) our 'sampling' of that period is 73 times more dense. Nevertheless, Fig 5 shows one feature that is also seen in our simulations, within year cycles (see e.g., Fig $4+1{ }^{\circ} \mathrm{C}$, either vpm $\mathrm{CO}_{2}$ concentration).

Fig 5. Alate density dynamics. Shown are the time series of alate aphid captures (normalized to the maximum number of captures, see Day et al. [42] for more details) and the associated spectral density function. Go to figure.

\subsection{Leaf Area Index $\left(L_{\mathrm{AI}}\right)$}

Fig 6 shows the Leaf Area Indices that result from the aphid density dynamics. Without aphids at $350 \mathrm{vpm} \mathrm{CO}_{2}$, increasing temperature generally increases the resulting LAIs, although toward the end of the 60 year rotation the ambient temperature ends up resulting in the highest LAI. Doubling the $\mathrm{CO}_{2}$ results in greater values of LAI for all temperature increments, although by the end of the rotation the different temperature trajectorys largely converge. With aphids, we see striking differences. At $350 \mathrm{vpm} \mathrm{CO}_{2}$, we see a complete reversal in the ordering of the LAIs. Now, $-2{ }^{\circ} \mathrm{C}$ results in the greatest LAI because aphid population densities are the lowest in these conditions (Fig 4A). A doubling of $\mathrm{CO}_{2}$ while generally resulting in higher LAIs does not fundamentally change the conclusion. $-2{ }^{\circ} \mathrm{C}$ still results in the greatest LAI, because aphid densities are still lowest at this temperature (Fig 4A).

Fig 6. Leaf Area Indices. Shown are the Leaf Area Indices $\left(\mathrm{m}^{2}\right.$ leaf $\mathrm{m}^{-2}$ of ground), Eq (1), for incremental temperature changes at $350 \mathrm{vpm}$ and $700 \mathrm{vpm} \mathrm{CO}_{2}$, with and without aphids. The LAI values result from changes in aphid density dynamics, see Fig 4. Go to figure.

Fig 7. Yield and C-sequestration. $\Delta$ Temperature is the increment in air and soil temperatures applied to the Eskdalemuir environment (Section 4.1, Fig 3). The $\mathrm{CO}_{2}$ concentration is denoted by the shading (dark color: $350 \mathrm{vpm}$, light color: $700 \mathrm{vpm}$ ). The aphid condition is denoted by the symbol ( $\bullet$ without aphids, $\mathbf{m}$ : with aphids). $Y_{\mathrm{C}}$ is the yield class $\left(\mathrm{m}^{3} \mathrm{ha}^{-1} \mathrm{y}^{-1}\right)$, defined as the volume $\left(\mathrm{m}^{3}\right)$ of timber harvested at the end of a rotation per hectare averaged over the duration of a rotation of 60 years; $C_{\text {sys }}\left(\mathrm{kg} \mathrm{C} \mathrm{m}^{-2}\right)$ is the total $\mathrm{C}$ in the system at the end of the $60 \mathrm{y}$ rotation. Results are shown for the no-aphid infestation situation (a steady state as applied in Fig 4) and for that when aphids are applied at time zero [Eq (64)]. Go to figure.

\subsection{C-sequestration $\left(C_{\text {sys }}\right)$ and plantation yield $\left(Y_{\mathrm{C}}\right)$}

The carbon-sequestration $\left(C_{\text {sys }}\right)$ and plantation yields $\left(Y_{\mathrm{C}}\right)$ follow from the effects of aphids density dynamics, and temperature and $\mathrm{CO}_{2}$ concentration changes. Fig 7 shows the four combinations of aphid presence and $\mathrm{CO}_{2}$ for each temperature increment. It is clear from the figure that doubling $\mathrm{CO}_{2}$ results in greater $\mathrm{C}$-sequestration and greater plantation yields at temperatures of $-1{ }^{\circ} \mathrm{C}$ to $+4{ }^{\circ} \mathrm{C}$. The presence of aphids results in lower $\mathrm{C}$-sequestration and lower plantation yields. In general these two effects seem to be approximately additive.

222

223 224 225 226 227 228 229 230 231 232 233 216 217 218 219 220 


\section{Discussion and conclusions}

The dynamics of the aphid populations is interesting due to its variety, ranging from aphids dying out (Fig $4 \mathrm{~A},-2{ }^{\circ} \mathrm{C}$ ) to various degrees of chaos with annual, biennial and triennial cycles (Fig 4). It is not surprising that chaos occurs rather robustly in the aphid-plant context. There is much non-linearity prevalent; there are far more than the minimum two state variables required for chaos; the equations are non-autonomous; and the intrinsic time scales of the dynamics of the aphid sub-model and the tree sub-model are very different and incommensurate $[43,44]$. This chaotic variety indicates that focusing on management/control strategies in order to minimize adverse consequences may be difficult, even with the assistance of a process-based model (for further consideration of chaotic aphid population dynamics see [45-49]).

\subsection{Comparisons with modeling studies}

The model described here is far from the first model to describe the population dynamics of aphids using simulation modelling. Appendix A summarizes 40 aphid simulation modelling studies. Where the present model differs from all but Newman et al. [25-29] is in (a) the treatment (mechanistic or otherwise) of the impacts of rising $\mathrm{CO}_{2}$ on plant growth and $(b)$ the use of the model to study impacts of climatic change. Both the present study and Newman et al. found that the mechanistic consequences of rising temperature tends to benefit aphid population growth while rising $\mathrm{CO}_{2}$ tends to be detrimental due to the changes in the plant caused by the rising $\mathrm{CO}_{2}$ (see also [26]).

Although there are similarities between the present model and that of Newman et al. [25], they differ in several important respects. For example, Newman et al.'s model is not stochiometrically complete as is the current model. Newman et al. also used their model to answer different questions, focused almost exclusively on the question of changes in aphid abundance. However, perhaps the most significant difference between the two studies is that Newman et al. use their model to study within year dynamics, while we used the present model to study an entire 60-year plantation rotation. By studying the dynamics over such a long period of time, we were able to predict the responses illustrated in Fig 4, which range from aphids dying out at low temperatures, to aphids having a severe impact on the productivity of managed spruce plantations (Fig 7B). Our work suggests that this may be a promising approach to investigating the impact of aphids on plant ecosystems in a changing climate. Our simulations indicate that, while temperature is the most important environmental variable, higher $\mathrm{CO}_{2}$ levels ameliorate the impact of aphid infestation on yield and carbon sequestration (Fig 7) and on leaf area index (Fig 6) and aphid dynamics (Fig 4). None of the previous modelling exercises have been able to provide such an integrated picture of the possible impacts of climatic change, let alone for plantation ecosystems.

\subsection{Model criticism, limitations and extensions}

The aphid model is so far untuned for any specific purpose although where possible parameter values were estimated for the green spruce aphid. Our analysis leans heavily on Dixon [4] and on Day et al. [3] who focus specifically on the green spruce aphid.

While we have tried to tie parameter values down to data and predictions to observations, this has been difficult, perhaps due to the traditions in this area of work. As mentioned earlier, we have not done any indiscriminate 'parameter-twiddling', which can be an endless process. With any model, it is preferable to fix parameters by experiments targeted at the level of the parameters than by adjustment with reference to the outcomes predicted by the model which depend on everything within the model; we know that all models are wrong in some respect. We have found that the occurrence 
of chaos and our general results are qualitatively not greatly affected by the details of parameterization, so long as the values assumed are in the right ball-park. The main conclusion is, we suggest, that mechanistic aphid-plant models may be an essential but difficult approach to understanding how these systems work.

\section{Acknowledgments}

The representation and parameterization of the Edinburgh Forest Model owe much to a long collaboration with Melvin Cannell and colleagues at the Institute for Terrestrial Ecology, Penicuik, Edinburgh. The work reported here is partly supported by the UK Department for Environment and Regions, contracts 1/1/160 and 1/1/64. JAN was supported by grants from the Canadian Natural Science and Engineering Research Council and from the Ontario Ministry of Agriculture, Food, and Rural Affairs. Wilfrid Laurier University and its campuses are located on the Haldimand tract, traditional territory of the Neutral, Anishnaabe and Haudenosaunee peoples. We recognize, honour, and respect these nations as the traditional stewards of the lands and water on which Laurier is now present.

\section{References}

1. Robinson EA, Ryan GD, Newman JA. A meta-analytical review of the effects of elevated $\mathrm{CO}_{2}$ on plant-arthropod interactions highlights the importance of interacting environmental and biological variables. New Phytologist. 2012;194(2):321-336.

2. Prather CM, Pelini SL, Laws A, Rivest E, Woltz M, Bloch CP, et al. Invertebrates, ecosystem services and climate change. Biological Reviews. 2013;88(2):327-348.

3. Day KR, Halldórsson G, Harding S, Straw NA. The Green Spruce Aphid in Western Europe: Ecology, Status, Impacts and Prospects for Management. vol. 4 of Forestry Commission Technical Paper 24. Forest Research, Alice Holt Lodge, Wrecclesham, Farnham, Surrey GL10 4LH, UK: The Research Communications Officer, Forest Research; 1998.

4. Dixon AFG. Aphid Ecology. 2nd ed. Chapman \& Hall; 1998.

5. Douglas AE. Phloem-sap feeding by animals: problems and solutions. Journal of Experimental Botany. 2006;57(4):747-754.

6. Straw N, Halldórsson G, Benedikz T. Damage sustained by individual trees: empirical studies on the impact of the green spruce aphid. In: Day K, Halldórsson G, Harding S, Straw NA, editors. The Green Spruce Aphid in Western Europe: Ecology, Status, Impacts and Prospects for Management. Forestry Commission Technical Paper 24. Alice Holt Lodge, Wrecclesham, Farnham, Surrey GL10 4LH, UK: Forestry Commission; 1998. p. 15-31.

7. Randle TJ, Ludlow AR. Growth costs to plantations: modelling the cumulative effect of defoliation by Elatobium. In: Day K, Halldórsson G, Harding S, Straw NA, editors. The Green Spruce Aphid in Western Europe: Ecology, Status, Impacts and Prospects for Management. Forestry Commission Technical Paper 24. Alice Holt Lodge, Wrecclesham, Farnham, Surrey GL10 4LH, UK: Forestry Commission; 1998. p. 32-40. 
8. Straw NA, et al. Climate change and the impact of green spruce aphid, Elatobium abietinum (Walker), in the UK. Scottish Forestry. 1995;49(3):134-145.

9. Stockwell D. The GARP modelling system: problems and solutions to automated spatial prediction. International Journal of Geographical Information Science. 1999;13(2):143-158.

10. Elith J, H Graham C, P Anderson R, Dudík M, Ferrier S, Guisan A, et al. Novel methods improve prediction of species' distributions from occurrence data. Ecography. 2006;29(2):129-151.

11. Scott JK, Yeoh PB. Bionomics and the predicted distribution of the aphid Brachycaudus rumexicolens (Hemiptera: Aphididae). Bulletin of Entomological Research. 1999;89(1):97-106.

12. Wyckhuys KAG, Koch RL, Kula RR, Heimpel GE. Potential exposure of a classical biological control agent of the soybean aphid, Aphis glycines, on non-target aphids in North America. Biological Invasions. 2009;11(4):857-871.

13. Wieczorek K, Bugaj-Nawrocka A. Invasive aphids of the tribe Siphini: a model of potentially suitable ecological niches. Agricultural and Forest Entomology. 2014;16(4):434-443.

14. Aljaryian R, Kumar L. Changing global risk of invading greenbug Schizaphis graminum under climate change. Crop Protection. 2016;88:137-148.

15. Macfadyen S, McDonald G, Hill MP. From species distributions to climate change adaptation: knowledge gaps in managing invertebrate pests in broad-acre grain crops. Agriculture, Ecosystems \& Environment. 2018;253:208-219.

16. Van der Putten WH, Macel M, Visser ME. Predicting species distribution and abundance responses to climate change: why it is essential to include biotic interactions across trophic levels. Philosophical Transactions of the Royal Society B: Biological Sciences. 2010;365(1549):2025-2034.

17. Berzitis EA, Minigan JN, Hallett RH, Newman JA. Climate and host plant availability impact the future distribution of the bean leaf beetle (Cerotoma trifurcata). Global Change Biology. 2014;20(9):2778-2792.

18. Harrington R, Woiwod I, Sparks T. Climate change and trophic interactions. Trends in Ecology \& Evolution. 1999;14(4):146-150.

19. Newman JA. Trophic interactions and climate change. In: Newton PC, Carran RA, Edwards GR, Niklaus PA, editors. Agroecosystems in a Changing Climate. Plenum Press, New York; 1988. p. 231-259.

20. DeAngelis DL, Yurek S. Spatially explicit modeling in ecology: a review. Ecosystems. 2017;20(2):284-300.

21. Thierry H, Vialatte A, Choisis JP, Gaudou B, Parry H, Monteil C. Simulating spatially-explicit crop dynamics of agricultural landscapes: The ATLAS simulator. Ecological Informatics. 2017;40:62-80.

22. Parry H, Evans AJ, Morgan D. Aphid population dynamics in agricultural landscapes: an agent-based simulation model. International Congress on Environmental Modelling and Software. 2004; p. 153. 
23. Wiest R, Salvadori JR, Fernandes JM, Lau D, Pavan W, Zanini WR, et al. Population growth of Rhopalosiphum padi under different thermal regimes: an agent-based model approach. Agricultural and Forest Entomology. 2020;

24. Picaza AR, Doloriel DM. An Agent-based computer simulation on Banana Bunchy Top Disease. International Journal of Environment, Agriculture and Biotechnology. 2018;3(2):239111.

25. Newman JA, Gibson DJ, Parsons AJ, Thornley JHM. How predictable are aphid population responses to elevated $\mathrm{CO}_{2}$ ? Journal of Animal Ecology. 2003;72(4):556-566.

26. Newman JA. Climate change and cereal aphids: the relative effects of increasing $\mathrm{CO}_{2}$ and temperature on aphid population dynamics. Global Change Biology. 2004;10(1):5-15.

27. Newman JA. Climate change and the fate of cereal aphids in Southern Britain. Global Change Biology. 2005;11(6):940-944.

28. Newman JA. Using the output from global circulation models to predict changes in the distribution and abundance of cereal aphids in Canada: a mechanistic modeling approach. Global Change Biology. 2006;12(9):1634-1642.

29. Hoover JK, Newman JA. Tritrophic interactions in the context of climate change: a model of grasses, cereal aphids and their parasitoids. Global Change Biology. 2004;10(7):1197-1208.

30. Skirvin D, Perry J, Harrington R. The effect of climate change on an aphid-coccinellid interaction. Global Change Biology. 1997;3(1):1-11.

31. Barlow N. Modelling aphid populations. New Zealand Journal of Ecology. 1981; p. $52-55$.

32. Dixon A, Barlow N. Population regulation in the lime aphid. Zoological Journal of the Linnean Society. 1979;67(3):225-237.

33. Barlow ND, Dixon AFG. Simulation of lime aphid population dynamics. Centre for Agricultural Publishing and Documentation; 1980.

34. Thornley JHM. Grassland Dynamics: An Ecosystem Simulation Model. CAB International; 1998.

35. Thornley JHM, Cannell MGR. Temperate grassland responses to climate change: an analysis using the Hurley pasture model. Annals of Botany. 1997;80(2):205-221.

36. Newman JA. Climate change and cereal aphids: the relative effects of increasing $\mathrm{CO}_{2}$ and temperature on aphid population dynamics. Global Change Biology. $2003 ; 10(1): 5-15$.

37. Thornley JHM. Modelling forest ecosystems: the Edinburgh Forest Model. In: Reynolds K, Thomson A, K ohl M, Shannon M, Ray D, Rennolls K, editors. Sustainable Forestry: From Monitoring and Modelling to Knowledge Management and Policy Science. Wallingford Oxon OX10 8DE UK: CAB International; 2007. p. 342-373.

38. Meteorological Office. Tables of temperature, relative humidity, precipitation and sunshine for the world. HM Stationery Office; 1980. 
39. Organización Meteorológica Mundial (Ginebra, Suiza). Climatological Normals (CLINO) for the period 1961-1990. Secretariat of the World Meteorological Organization; 1996.

40. Martinez-Lozano JA, Tena F, Onrubia JE, De La Rubia J. The historical evolution of the Ångström formula and its modifications: review and bibliography. Agricultural and Forest Meteorology. 1984;33(2-3):109-128.

41. McBurnett M. Probing the underlying structure in dynamical systems: an introduction to spectral analysis. In: Kiel LD, Elliot E, editors. Chaos Theory in the Social Sciences: Foundations and Applications. Ann Arbor, MI: The University of Michigan Press; 1997. p. 31-51.

42. Day KR, Ayres MP, Harrington R, Kidd NA. Interannual dynamics of aerial and arboreal green spruce aphid populations. Population Ecology. 2010;52(2):317-327.

43. Baker GL, Baker GL, Gollub JP. Chaotic Dynamics: An Introduction. 2nd ed. Cambridge University Press; 1996.

44. Acheson D. From Calculus to Chaos: An Introduction to Dynamics. Oxford University Press; 1997.

45. Ma Z, Bechinski EJ. An approach to the nonlinear dynamics of Russian wheat aphid population growth with the cusp catastrophe model. Entomological Research. 2009;39(3):175-181.

46. Piyaratne M, Zhao H, Meng Q. APHIDSim: A population dynamics model for wheat aphids based on swallowtail catastrophe theory. Ecological Modelling. 2013;253:9-16.

47. Piyaratne M. Catastrophic behavior of aphid population dynamics: An analysis of swallowtail model. Computational Ecology and Software. 2014;4(3):135.

48. Piyaratne M, Zhao H, Zuqing H, Xiangshun H, Wang Y, Bailing W. A model to analyze weather impact on aphid population dynamics: an application on swallowtail catastrophe model. European Scientific Journal. 2014;10(18).

49. Wu W, Piyaratne M, Zhao H, Li C, Hu Z, Hu X. Butterfly catastrophe model for wheat aphid population dynamics: Construction, analysis and application. Ecological Modelling. 2014;288:55-61.

50. Wiktelius S, Pettersson J. Simulations of bird cherry — oat aphid population dynamics: A tool for developing strategies for breeding aphid-resistant plants. Agriculture, Ecosystems \& Environment. 1985;14(3-4):159-170.

51. Ekbom B, Wiktelius S, Chiverton P. Can polyphagous predators control the bird cherry-oat aphid (Rhopalosiphum padi) in spring cereals?: A simulation study. Entomologia Experimentalis et Applicata. 1992;65(3):215-223.

52. Morgan D. Population dynamics of the bird cherry-oat aphid, Rhopalosiphum padi (L.), during the autumn and winter: a modelling approach. Agricultural and Forest Entomology. 2000;2(4):297-304.

53. Parry HR, Evans AJ, Morgan D. Aphid population response to agricultural landscape change: a spatially explicit, individual-based model. Ecological Modelling. 2006;199(4):451-463. 
54. Thackray DJ, Diggle AJ, Jones RAC. BYDV PREDICTOR: a simulation model to predict aphid arrival, epidemics of barley yellow dwarf virus and yield losses in wheat crops in a Mediterranean-type environment. Plant Pathology. 2009;58(1):186-202.

55. Ma ZS, Bechinski EJ. A survival-analysis-based simulation model for Russian wheat aphid population dynamics. Ecological Modelling. 2008;216(3-4):323-332.

56. Carter N, Rabbinge R. Simulation models of the population development of Sitobion avenae. IOBC/WPRS Bulletin. 1980;3:93-98.

57. Carter N, Dixon AFG, Rabbinge R. Cereal Aphid Populations: Biology, Simulation and Prediction. Pudoc; 1982.

58. Rabbinge R, Ankersmit G, Pak G. Epidemiology and simulation of population development of Sitobion avenae in winter wheat. Netherlands Journal of Plant Pathology. 1979;85(5):197-220.

59. van Roermund H, Groot J, Rossing W, Rabbinge R. Calculation of aphid damage in winter wheat, using a simulation model. Mededelingen-Universiteit Gent, Faculteit Landbouwkundige en Toegepaste Biologische Wetenschappen. 1986;51(3a):1125-1130.

60. Rossing W. Simulation of damage in winter wheat caused by the grain aphid Sitobion avenae. 2. Construction and evaluation of a simulation model. Netherlands Journal of Plant Pathology. 1991;97(1):25-54.

61. Freier B, Triltsch H, Rossberg D. GTLAUS-A model of wheat-cereal aphid-predator interaction and its use in complex agroecological studies. Journal of Plant Diseases and Protection. 1996; p. 543-554.

62. Gosselke U, Triltsch H, Rossberg D, Freier B. GETLAUS01-the latest version of a model for simulating aphid population dynamics in dependence on antagonists in wheat. Ecological Modelling. 2001;145(2-3):143-157.

63. Duffy C, Fealy R, Fealy RM. An improved simulation model to describe the temperature-dependent population dynamics of the grain aphid, Sitobion avenae. Ecological Modelling. 2017;354:140-171.

64. van Roermund H, Groot J, Rossing W, Rabbinge R. Stimulation of aphid damage in winter wheat. NJAS Wageningen Journal of Life Sciences. 1986;34(4):488-493.

65. Hughes R, Gilbert N. A model of an aphid population-a general statement. The Journal of Animal Ecology. 1968; p. 553-563.

66. Gilbert N, Hughes R. A model of an aphid population-three adventures. The Journal of Animal Ecology. 1971; p. 525-534.

67. Raworth D. Population dynamics of the cabbage aphid, Brevicoryne Brassicae (Homoptera: Aphididae) at Vancouver, British Columbia: V. A simulation model. The Canadian Entomologist. 1984;116(6):895-911.

68. Gutierrez A, Baumgärtner J, Summers C. Multitrophic models of predator-prey energetics: I. Age-specific energetics models-pea aphid Acyrthosiphon pisum (Homoptera: Aphididae) as an example. The Canadian Entomologist. 1984;116(7):923-932. 
69. Snyder WE, Ives AR. Interactions between specialist and generalist natural enemies: parasitoids, predators, and pea aphid biocontrol. Ecology. 2003;84(1):91-107.

70. Kindlmann P. A model of aphid population with age structure. In: Capasso V, Grosso E, Paveri-Fontana SL, editors. Mathematics in Biology and Medicine. vol. 57 of Lecture Notes in Biomathematics. Berlin, Heidelberg: Springer; 2007. p. $72-77$.

71. Xia JY, Wang J, Cui JJ, Leffelaar PA, Rabbinge R, van der Werf W. Development of a stage-structured process-based predator-prey model to analyse biological control of cotton aphid, Aphis gossypii, by the sevenspot ladybeetle, Coccinella septempunctata, in cotton. Ecological Complexity. 2018;33:11-30.

72. Gutierrez A, Havenstein D, Nix H, Moore P. The ecology of Aphis craccivora Koch and subterranean clover stunt virus in south-east Australia. II. A model of cowpea aphid populations in temperate pastures. Journal of Applied Ecology. 1974; p. 1-20.

73. Gutierrez A, Nix H, Havenstein D, Moore P. The ecology of Aphis craccivora Koch and subterranean clover stunt virus in south-east Australia. III. A regional perspective of the phenology and migration of the cowpea aphid. Journal of Applied Ecology. 1974; p. 21-35.

74. Whalon ME, Smilowitz Z. Temperature-dependent model for predicting field populations of green peach aphid, Myzus persicae (Homoptera: Aphididae). The Canadian Entomologist. 1979;111(9):1025-1032.

75. Tamaki G, Long GE. Predator complex of the green peach aphid on sugarbeets: expansion of the predator power and efficacy model. Environmental Entomology. 1978;7(6):835-842.

76. Ro TH, Long GE. GPA-Phenodynamics, a simulation model for the population dynamics and phenology of green peach aphid in potato: formulation, validation, and analysis. Ecological Modelling. 1999;119(2-3):197-209.

77. Bertschinger L, Keller ER, Gessler C. Development of EPIVIT, a simulation model for contact-and aphid-transmitted potato viruses. Phytopathology. 1995;85(7):801-814.

78. Miksanek JR, Heimpel GE. A matrix model describing host-parasitoid population dynamics: The case of Aphelinus certus and soybean aphid. PLoS One. 2019;14(6):e0218217.

79. Gilbert N, Gutierrez A. A plant-aphid-parasite relationship. The Journal of Animal Ecology. 1973; p. 323-340.

80. Augustin DC, Fineberg MS, Johnson BB, Linebarger RN, Sansom FJ, Strauss JC. The SCI Continuous System Simulation Language (CSSL). Simulation. 1967;9:281-303.

81. Thornley JHM, France J. Mathematical Models in Agriculture: Quantitative Methods for the Plant, Animal and Ecological Sciences. CABI; 2007.

82. Thornley JHM. A transport-resistance model of forest growth and partitioning. Annals of Botany. 1991;68(3):211-226. 
83. Thornley JHM. Modelling water in crops and plant ecosystems. Annals of Botany. 1996;77(3):261-275.

84. Thornley JHM, Cannell MGR. Temperate forest responses to carbon dioxide, temperature and nitrogen: a model analysis. Plant, Cell \& Environment. 1996;19(12):1331-1348.

85. Cannell MGR, Thornley JHM, Mobbs DC, Friend AD. UK conifer forests may be growing faster in response to increased $\mathrm{N}$ deposition, atmospheric $\mathrm{CO}_{2}$ and temperature. Forestry: An International Journal of Forest Research. 1998;71(4):277-296.

86. Thornley JHM. Dynamic model of leaf photosynthesis with acclimation to light and nitrogen. Annals of Botany. 1998;81(3):421-430.

87. Cannell MGR, Thornley JHM. Modelling the components of plant respiration: some guiding principles. Annals of Botany. 2000;85(1):45-54.

88. Thornley JHM, Cannell MGR. Managing forests for wood yield and carbon storage: a theoretical study. Tree Physiology. 2000;20(7):477-484.

89. Thompson GA, Schulz A. Macromolecular trafficking in the phloem. Trends in Plant Science. 1999;4(9):354-360.

90. Parry W. The effect of needle age on the acceptability of Sitka spruce needles to the aphid, Elatobium abietinum (Walker). Oecologia. 1976;23(4):297-313.

91. Dean GJ. Effect of temperature on the cereal aphids Metopolophium dirhodum (Wlk.), Rhopalosiphum padi (L.) and Macrosiphum avenue (F.)(Hem., Aphididae). Bulletin of Entomological Research. 1974;63(3):401-409.

92. De Barro PJ. The role of temperature, photoperiod, crowding and plant quality on the production of alate viviparous females of the bird cherry-oat aphid, Rhopalosiphum padi. Entomologia Experimentalis et Applicata. 1992;65(3):205-214.

93. Fisher M. Morph determination in Elatobium abietinum (Walk.) the green spruce aphid. University of East Anglia; 1982. 


\section{Appendix A Aphid simulation models}

Tab A.1. Summary of aphid simulation models. 'TD aphid' denotes that aphid growth is represented in the model as temperature-dependent; similarly 'TD plant' denotes that plant growth is represented as temperature-dependent. ' $\mathrm{CO}_{2}$ plant' denotes whether the model considers the $\mathrm{CO}_{2}$ concentration and its mechanistic effects on plant growth. 'Climate $\Delta$ ' denotes whether climate change is explicitly considered or not. The 'Stated purpose' indicates the purpose of the model according to the authors. '??' denotes that the information was not presented in the noted reference.

\begin{tabular}{lllllll}
\hline $\begin{array}{l}\text { Reference } \\
\text { (Year) }\end{array}$ & TD & Plant & TD & $\mathrm{CO}_{2}$ & Climate & Stated purpose \\
\hline
\end{tabular}

\begin{tabular}{|c|c|c|c|c|c|}
\hline \multicolumn{6}{|c|}{ Aphids that feed on $g$} \\
\hline \multicolumn{6}{|c|}{ Bird cherry-oat aphid ( } \\
\hline $\begin{array}{l}\text { Wiktelius \& } \\
\text { Pettersson } \\
{[50](1985)}\end{array}$ & Yes & None & $\mathrm{N} / \mathrm{A}$ & $\mathrm{N} / \mathrm{A}$ & No \\
\hline $\begin{array}{l}\text { Ekbom et } \\
\text { al. [51] (1992) }\end{array}$ & Yes & $\begin{array}{l}\text { Spring } \\
\text { barley }\end{array}$ & Yes & No & No \\
\hline $\begin{array}{l}\text { Morgan [52] } \\
(2000)\end{array}$ & Yes & $\begin{array}{l}\text { Winter } \\
\text { barley }\end{array}$ & No & No & No \\
\hline $\begin{array}{l}\text { Newman et } \\
\text { al. [25-29] } \\
(2003-2006)\end{array}$ & Yes & Grass & Yes & Yes & Yes \\
\hline $\begin{array}{l}\text { Parry et } \\
\text { al. [53] (2006) }\end{array}$ & Yes & None & $\mathrm{N} / \mathrm{A}$ & $\mathrm{N} / \mathrm{A}$ & No \\
\hline $\begin{array}{l}\text { Thackray et } \\
\text { al. [54] (2009) }\end{array}$ & No & Wheat & No & No & No \\
\hline
\end{tabular}

Russian wheat aphid (Diuraphis noxia Kurdjumov)

\begin{tabular}{|c|c|c|c|c|c|c|}
\hline $\begin{array}{l}\text { Ma et al. [55] } \\
\text { (2008) }\end{array}$ & Yes & Barley & Yes & No & No & None stated \\
\hline
\end{tabular}
(2008) 
bioRxiv preprint doi: https://doi.org/10.1101/2021.05.26.445772; this version posted May 26, 2021. The copyright holder for this preprint (which was not certified by peer review) is the author/funder, who has granted bioRxiv a license to display the preprint in perpetuity. It is made available under aCC-BY 4.0 International license.

continued from previous page

\begin{tabular}{lllllll}
\hline $\begin{array}{l}\text { Reference } \\
\text { (Year) }\end{array}$ & TD & Plant & TD & $\mathrm{CO}_{2}$ & Climate & Stated purpose \\
\hline
\end{tabular}

English Grain Aphid (Sitobion avenae Fabricius)

\begin{tabular}{|c|c|c|c|c|c|}
\hline $\begin{array}{l}\text { Carter et } \\
\text { al. }[56,57] \\
(1980)\end{array}$ & Yes & $\begin{array}{l}\text { Winter } \\
\text { wheat }\end{array}$ & Yes & No & No \\
\hline $\begin{array}{l}\text { Rabbinge et } \\
\text { al. }[58,59] \\
(1979)\end{array}$ & Yes & Wheat & Yes & No & No \\
\hline $\begin{array}{l}\text { Skirvin et } \\
\text { al. [30] (1997) }\end{array}$ & Yes & None & $\mathrm{N} / \mathrm{A}$ & $\mathrm{N} / \mathrm{A}$ & Yes \\
\hline $\begin{array}{l}\text { Rossing [60] } \\
\text { (1991) }\end{array}$ & Yes & $\begin{array}{l}\text { Winter } \\
\text { wheat }\end{array}$ & Yes & No & No \\
\hline $\begin{array}{l}\text { Freier et } \\
\text { al. }[61,62] \\
(1996,2001)\end{array}$ & Yes & $\begin{array}{l}\text { Winter } \\
\text { wheat }\end{array}$ & Yes & No & No \\
\hline $\begin{array}{l}\text { Duffy et } \\
\text { al. [63] (2017) }\end{array}$ & Yes & $\begin{array}{l}\text { Cereal } \\
\text { crop }\end{array}$ & No & No & No \\
\hline $\begin{array}{l}\text { Rossing [60] } \\
\text { (1991) }\end{array}$ & Yes & $\begin{array}{l}\text { Winter } \\
\text { wheat }\end{array}$ & Yes & No & No \\
\hline $\begin{array}{l}\text { van } \\
\text { Roermund et }\end{array}$ & Yes & $\begin{array}{l}\text { Winter } \\
\text { wheat }\end{array}$ & Yes & No & No \\
\hline
\end{tabular}

al. [64] (1986)

\section{Aphids that feed on forb host plants}

cabbage aphid (Brevicoryne brassicae L.)

\begin{tabular}{|c|c|c|c|c|c|c|}
\hline $\begin{array}{l}\text { Hughes \& } \\
\text { Gilbert [65] } \\
(1968)\end{array}$ & Yes & None & $\mathrm{N} / \mathrm{A}$ & $\mathrm{N} / \mathrm{A}$ & No & $\begin{array}{l}\text { "[T] ool to understand the combined effects of species } \\
\text { interactions and environmental factors on population } \\
\text { growth }\end{array}$ \\
\hline $\begin{array}{l}\text { Gilbert \& } \\
\text { Hughes }[66] \\
(1971)\end{array}$ & Yes & None & $\mathrm{N} / \mathrm{A}$ & $\mathrm{N} / \mathrm{A}$ & No & $\begin{array}{l}\text { "... refinement used to examine biocontrol } \\
\text { strategies." }\end{array}$ \\
\hline $\begin{array}{l}\text { Raworth [67] } \\
(1984)\end{array}$ & Yes & kale & Yes & No & No & $\begin{array}{l}\text { "This paper consolidates information from the } \\
\text { previous studies in the form of a simulation model." }\end{array}$ \\
\hline
\end{tabular}


bioRxiv preprint doi: https://doi.org/10.1101/2021.05.26.445772; this version posted May 26, 2021. The copyright holder for this preprint (which was not certified by peer review) is the author/funder, who has granted bioRxiv a license to display the preprint in perpetuity. It is made available under aCC-BY 4.0 International license.

continued from previous page

\begin{tabular}{lllllll}
\hline $\begin{array}{l}\text { Reference } \\
\text { (Year) }\end{array}$ & TD & Plant & TD & $\mathrm{CO}_{2}$ & Climate & Stated purpose \\
\hline
\end{tabular}

pea aphid (Acyrthosiphon pisum Harris)

Gutierrez et $\quad$ Yes $\quad$ Alfalfa ?? No No

al. [68] (1984)

Snyder \& No None N/A N/A No

Ives [69]

(2003)

No None N/A N/A No

"[E]xpands a model for energy or biomass assimilation by individuals, that has been proposed in various forms in the literature, to model the growth, development, reproduction, ageing and survivorship of the pea aphid."

"We investigated how specialist and generalist natural enemies differ as biological control agents of pea aphids (Acyrthosiphon pisum), and how interactions among natural enemies affect successful control."

\begin{tabular}{|c|c|c|c|c|c|c|}
\hline \multicolumn{7}{|c|}{ black bean aphid (Aphis fabae) } \\
\hline $\begin{array}{l}\text { Kindlmann } \\
{[70] \text { (1985) }}\end{array}$ & No & None & $\mathrm{N} / \mathrm{A}$ & $\mathrm{N} / \mathrm{A}$ & No & not stated \\
\hline \multicolumn{7}{|c|}{ cotton aphid (Aphis gossypii) } \\
\hline $\begin{array}{l}\text { Xia et al. [71] } \\
(2018)\end{array}$ & Yes & None & $\mathrm{N} / \mathrm{A}$ & $\mathrm{N} / \mathrm{A}$ & No & $\begin{array}{l}\text { "To better understand and characterize the } \\
\text { predator-prey system dynamics under field } \\
\text { conditions." }\end{array}$ \\
\hline \multicolumn{7}{|c|}{ cowpea aphid (Aphis craccivora Koch) } \\
\hline $\begin{array}{l}\text { Gutierrez et } \\
\text { al. }[72,73] \\
(1974)\end{array}$ & & Clover & Yes & No & No & $\begin{array}{l}\text { "... describing the interactions of various } \\
\text { components of the biology of cowpea aphid (Aphis } \\
\text { craccivora Koch), its host plant, Subterranean Clover } \\
\text { Stunt Virus (SCSV)." }\end{array}$ \\
\hline \multicolumn{7}{|c|}{ green peach aphid (Myzus persicae Sulz.) } \\
\hline $\begin{array}{l}\text { Whalon \& } \\
\text { Smilowitz [74] } \\
(1979)\end{array}$ & Yes & Potato & No & No & No & $\begin{array}{l}\text { "This is a report of predictive temperature-dependent } \\
\text { density equations for green peach aphid field } \\
\text { populations." }\end{array}$ \\
\hline $\begin{array}{l}\text { Tamaki \& } \\
\text { Long }[75] \\
(1978)\end{array}$ & Yes & None & $\mathrm{N} / \mathrm{A}$ & $\mathrm{N} / \mathrm{A}$ & No & $\begin{array}{l}\text { "A model to evaluate potential reductive impact of } \\
\text { populations of green peach aphid, Myzus persicae } \\
\text { (Sulzer), by predators was generalized to include } \\
\text { effects of temperature on the rate of aphid } \\
\text { reproduction and the functional response of the } \\
\text { predator complex." }\end{array}$ \\
\hline \multirow[t]{2}{*}{$\begin{array}{l}\text { Ro \& } \\
\text { Long }[76] \\
(1999)\end{array}$} & Yes & Potato & No & No & No & $\begin{array}{l}\text { "[T] he model describes the interaction among the } \\
\text { green peach aphid population, its predators, and } \\
\text { abiotic factors (e.g. temperature). The model } \\
\text { includes functions for population growth of the aphid } \\
\text { and its predator complex." }\end{array}$ \\
\hline & & & & & & continued on next page \\
\hline
\end{tabular}


bioRxiv preprint doi: https://doi.org/10.1101/2021.05.26.445772; this version posted May 26, 2021. The copyright holder for this preprint (which was not certified by peer review) is the author/funder, who has granted bioRxiv a license to display the preprint in perpetuity. It is made available under aCC-BY 4.0 International license.

\begin{tabular}{lllllll}
\hline \multicolumn{2}{|l}{ continued from } & previous page \\
\hline $\begin{array}{l}\text { Reference } \\
\text { (Year) }\end{array}$ & $\begin{array}{l}\text { TD } \\
\text { aphid }\end{array}$ & $\begin{array}{c}\text { Plant } \\
\text { species }\end{array}$ & $\begin{array}{l}\text { TD } \\
\text { plant }\end{array}$ & $\begin{array}{l}\mathbf{C O}_{2} \\
\text { plant }\end{array}$ & $\begin{array}{l}\text { Climate } \\
\Delta\end{array}$ & Stated purpose \\
\hline \multicolumn{1}{l}{$\begin{array}{l}\text { Bertschinger } \\
\text { et al. [77] } \\
(1995)\end{array}$} & Yes & Potato & Yes & No & No & $\begin{array}{l}\text { "A model (EPIVIT) was developed for the simulation } \\
\text { of potato harvest infection (\% infected tubers) with a } \\
\text { contct- or aphid-transmitted virus." }\end{array}$
\end{tabular}

\begin{tabular}{|c|c|c|c|c|c|}
\hline \multicolumn{6}{|c|}{ soybean aphid (Aphis glycines Matsumura) } \\
\hline $\begin{array}{l}\text { Miksanek \& } \\
\text { Heimpel [78] } \\
(2019)\end{array}$ & Yes & None & $\mathrm{N} / \mathrm{A}$ & No & $\begin{array}{l}\text { "We apply this approach to investigate the effect of } \\
\text { parasitism by the Asian parasitoid Aphelinus certus } \\
\text { on its host, the soybean aphid (Aphis glycines)." }\end{array}$ \\
\hline \multicolumn{6}{|c|}{ Aphids that feed on tree host plants } \\
\hline
\end{tabular}

Day et al. [42] Yes None N/A N/A No "[T]he patterns of insect abundance on trees have (2010) never been satisfactorily described by a numerical model despite considerable knowledge of endogenous and exogenous factors in the population dynamics of the species."

\begin{tabular}{|c|c|c|c|c|c|}
\hline \multicolumn{6}{|c|}{ lime aphid (Eucallipterus tiliae L.) } \\
\hline $\begin{array}{l}\text { Barlow } \\
{[31-33]} \\
(1979-1981)\end{array}$ & Yes & $\begin{array}{l}\text { Lime } \\
\text { tree }\end{array}$ & No & No & $\begin{array}{l}\text { "This paper considers two approaches to the } \\
\text { modelling of aphid populations. Using the lime aphid } \\
\text { (Eucallipterus tiliae L.) as an example, it discusses } \\
\text { the well-established role of detailed simulation } \\
\text { models in the study of aphid population dynamics } \\
\text { then considers the possible application of a simple, } \\
\text { general herbivore/plant model to aphids." }\end{array}$ \\
\hline \multicolumn{6}{|c|}{ Aphids that feed on vine host plants } \\
\hline \multicolumn{6}{|c|}{ thimbleberry aphid (Masonaphis maxima Mason) } \\
\hline $\begin{array}{l}\text { Gilbert \& } \\
\text { Gutierrez [79] } \\
(1973)\end{array}$ & $? ?$ & $\begin{array}{l}\text { Thim- } \\
\text { ble- } \\
\text { berry }\end{array}$ & $? ?$ & No & $\begin{array}{l}\text { "[To] explore effects of parasitism and competition on } \\
\text { aphid population growth." }\end{array}$ \\
\hline
\end{tabular}

Return to Section 1 or Section 1.2.3 


\section{Appendix B Numerical methods}

The efm is programmed in ACSL, Advanced Continuous Simulation Language, a highly readable fortran-like language (Aegis Research Corporation, Huntsville, AL - email: acsl-sales@aegisrc.com) and is extensively commented. ACSL follows the long established CSSL (Continuous System Simulation Language) standard ([80]) — designed for models which can be represented by ordinary differential equations using the 'rate-state' formalism (rate of change is a function of state variables + driving variables + parameters). A significant advantage of ACSL is that it is non-procedural-that is, the statements can be placed in any order; in the first step, translation, places the statements in an executable order, which can then be compiled and linked as usual. The non-procedural capability allows the programmer to put the statements in an order that makes biological sense. The version of ACSL used here is 11.8.4- now unfortunately legacy software, although to our knowledge there is no adequate replacement. We have used double precision (single precision fails), with translator and runtime table sizes of 200000. The compiler used is Compaq Visual Fortran 6.6-1877-47BAQ, compiling in 36 s. The linker is Microsoft (R) Incremental Linker Version 6.00.8447. Those wishing to use this excellent and much used software system, may contact Professor Parsons at Massey University, New Zealand: a.j.parsons@massey.ac.nz ). The program, efm.csl, which includes the aphid sub-model as an option, is freely available from the senior author. It can also be downloaded from https://sites.massey.ac.nz/hurleypasturemodel/ edinburgh-forestry-model/. The time step (maxt) is about 11 minutes (1/128 d) and Euler's method of integration is applied ([81], pp. 27-40). It takes about eight seconds to simulate one year on a $1.6 \mathrm{GHz}$ pc running under Windows 7 with a 32 -bit operating system. 


\section{Appendix C Edinburgh Forest Model}

We couple the aphid sub-model (see next section) with the Edinburgh Forest Model (efm). The efm is a mature and well-validated mechanistic simulator applicable to evergreen or deciduous forest ecosystems ([37]. See Appendix B for the numerical methods employed). These can be grown as plantations, managed forests, or unmanaged forests. The model is based on simplified physiology and biochemistry with soil and water sub-models. The efm couples carbon (C), nitrogen (N) and water, fluxes and pools and provides stoichiometric balancing of the items represented.

Here we used the efm in the evergreen forest mode, parameterized for Sitka spruce growing in a north British environment (Section 4.1). The elements of the efm relevant to the aphids are described here. In evergreen mode, foliage is always present and the aphids can live on the foliage year-round, with (in some situations) negligible immigration and emigration. Horizontal homogeneity is assumed. The efm comprises linked sub-models which are described elsewhere for the trees [82], soil and litter ([34], chapter 5) and water ([83]; [34], chapter 6). Synopses of processes represented are given by Thornley [37], Thornley and Cannell [84] and Cannell et al. [85]. Recent developments of the model are: acclimation of photosynthesis to light, nitrogen, carbon dioxide and temperature [86]; components of respiration are more explicitly itemised [87]. See also the appendix of Thornley and Cannell [88] for diagrams of the efm.

Symbols relevant to the present application are listed in Appendix E. Important tree variables vis-à-vis the aphid sub-model are the leaf area per stem, $A_{\text {leaf }}\left(\mathrm{m}^{2} \mathrm{stem}^{-1}\right)$; stem density, $n_{\text {stems }}$ (number of stems per $\mathrm{m}^{2}$, a state variable of the efm); leaf area index, LAI $\left[\mathrm{m}^{2}\right.$ leaf $\left.\left(\mathrm{m}^{2} \text { ground }\right)^{-1}\right]$; these are given by:

$$
\begin{aligned}
& A_{\text {leaf }}=\sum_{i=\jmath}^{4} A_{\text {leaf }},\left(A_{\text {leaf }} \text { are efm state variables }\right) . \\
& \quad A_{\text {leaf }}(t=0)=0.012 \mathrm{~m}^{2} \mathrm{stem}^{-1} . \\
& \frac{\mathrm{d} n_{\text {stem }}}{\mathrm{d} t}=-O_{\text {nstems, th }}, \quad n_{\text {stems }}(t=0)=0.25 \text { stems } \mathrm{m}^{-2} . \\
& L_{\mathrm{AI}}=n_{\text {stems }} A_{\text {leaf }}, \quad L_{\mathrm{AI}}(t=0)=0.003 \mathrm{~m}^{2} \text { leaf }\left(\mathrm{m}^{2} \text { ground }\right)^{-1} .
\end{aligned}
$$

In Eq (1a), leaf area per stem, $A_{\text {leaf }}$, is represented by four age categories, 1-4 (Fig 1). The time $t=0$ values each of these variables is $0.003 \mathrm{~m}^{2} \mathrm{stem}^{-1}$. In the forest

plantation simulations (Section 4.2) aphid infestation is assumed to occur at $t=0$ [Eqs (4), (5) and (64)].

In the second equation, there is a single flux out of the $n_{\text {stems }}$ state variable, $O_{\text {nstems,th }}\left(\right.$ stems $\mathrm{m}^{-2} \mathrm{~d}^{-1}$ ) due to the management thinning regime (Section 4.2, first paragraph). Pruning is not included in our present simulations of aphid infestation; it is included in the model but is set to zero [Eq (14)].

Other important variables for the aphid implementation of the efm are the carbon $(\mathrm{C})$ substrate and nitrogen $(\mathrm{N})$ substrate concentrations in the foliage (leaf, le), $C_{\text {le }}$ and $N_{\text {le. }}$. Although the phloem $\mathrm{C}$ and $\mathrm{N}$ concentrations are not directly represented in the forest model, it is assumed that they can be obtained from the foliage (leaf) substrate concentrations, $C_{\mathrm{le}}$ and $N_{\mathrm{le}}$ [kg substrate C, substrate N (kg structural dry matter) ${ }^{-1}$ ] 
by simple multipliers:

$$
\begin{aligned}
& C_{\text {phloem }}=m_{\mathrm{CS}} C_{\mathrm{le}} N_{\text {phloem }}=m_{\mathrm{NS}} N_{\text {le }} \\
& m_{\mathrm{CS}}=5000, \quad m_{\mathrm{NS}}=1000 \text { structural dry matter } \mathrm{m}^{-2} \\
& \text { At time } t=0, \quad C_{\mathrm{le}}=0.02 \mathrm{~kg} \text { substrate } \mathrm{C}(\mathrm{kg} \text { structural dry matter })^{-1} \\
& N_{\mathrm{le}}=0.01 \mathrm{~kg} \text { substrate } \mathrm{N}(\mathrm{kg} \text { structural dry matter })^{-1} \\
& C_{\text {phloem }}=100 \mathrm{~kg} \text { substrate } \mathrm{C}\left(\mathrm{m}^{3}{\text { phloem sap })^{-1}}\right. \\
& N_{\text {phloem }}=10 \mathrm{~kg} \text { substrate } \mathrm{C}\left(\mathrm{m}^{3}{\text { phloem sap })^{-1}}\right.
\end{aligned}
$$

In Eq (2) the units of the phloem $\mathrm{C}$ and $\mathrm{N}$ concentrations, $C_{\text {phloem }}$ and $N_{\text {phloem }}$, are $\mathrm{kg} \quad 373$ substrate $\mathrm{C}$, substrate $\mathrm{N}\left(\mathrm{m}^{3} \text { phloem sap }\right)^{-1}$ in the phloem. The values for the multipliers $m_{\mathrm{CS}}$ and $m_{\mathrm{NS}}$ are chosen so that reasonable values of phloem concentrations are obtained $[5,89]$. For example, at time $t=0, C_{\mathrm{le}}=0.02 \mathrm{~kg}$ substrate $\mathrm{C}$ ( $\mathrm{kg}$ structural dry matter $)^{-1}$ converts to $C_{\text {phloem }}=100(=5000 \times 0.02) \mathrm{kg}$ substrate $\mathrm{C}\left(\mathrm{m}^{3} \text { phloem }\right)^{-1}$ $=100 \mathrm{~g}$ substrate $\mathrm{C}$ (litre phloem $)^{-1}=100 / 144 \mathrm{~mol}$ sucrose litre ${ }^{-1}=0.7$ molar sucrose in phloem (assuming that sucrose is $\left.\mathrm{C}_{12} \mathrm{H}_{22} \mathrm{O}_{11}\right) ; N_{\text {le }}=0.01 \mathrm{~kg}$ substrate $\mathrm{N}(\mathrm{kg}$ structural dry matter $)^{-1}$ converts to $10(=1000 \times 0.01) \mathrm{kg} \mathrm{N} \mathrm{m}^{-3}=10 \mathrm{~g} \mathrm{~N} \mathrm{litre}^{-1}$ $=10 / 14=0.7$ molar glutamate (assuming that glutamic acid is $\mathrm{C}_{5} \mathrm{H}_{9} \mathrm{NO}_{4}$ ).

The phloem C:N substrate ratio $\left[\mathrm{kg} \mathrm{C}(\mathrm{kg} \mathrm{N})^{-1}\right]$ is [with $\left.\mathrm{Eq}(2)\right]$

$$
\begin{aligned}
r_{\mathrm{CNphloem}} & =\frac{C_{\text {phloem }}}{N_{\text {phloem }}}, r_{\mathrm{CNphloem}}(t=0)=\frac{m_{\mathrm{CS}} C_{\mathrm{le}}(t=0)}{m_{\mathrm{NS}} N_{\mathrm{le}}(t=0)} \\
& =\frac{5000}{1000} \frac{0.02}{0.01}=10\left[\mathrm{~kg} \text { substrate } \mathrm{C}(\mathrm{kg} \text { substrate } \mathrm{N})^{-1}\right]
\end{aligned}
$$




\section{Appendix D Aphid submodel}

\section{Contents}

D.1 Apterous (wingless) adult aphids, $\boldsymbol{a}_{\mathrm{pta}} \ldots \ldots \ldots \ldots \ldots$

D.1.1 Inputs: apterous (wingless) adult aphids . . . . . . . . . 25

D.1.2 Outputs: apterous (wingless) adult aphids . . . . . . . . 25

D.1.3 Differential equation: apterous (wingless) adult aphids . . . . . . 28

D.2 Apterous aphid fecundity . . . . . . . . . . . . . . . 28

D.2.1 Apterous aphid fecundity as a function of temperature . . . . . 28

D.2.2 Apterous aphid fecundity as a function of phloem $\mathrm{N}$ concentration 29

D.3 Alate:apterous ratio in offspring from apterous adults . . . . . . . . . 30

D.3.1 Alate:apterous ratio as a function of temperature . . . . . . . . 30

D.3.2 Alate:apterous ratio as a function of aphid total density . . . . . 31

D.3.3 Alate:apterous ratio as a function of nutritional status . . . . . . 31

D.3.4 Total fecundity and the fractional fecundity of apterous adults . 32

D.3.5 Associated $\mathrm{N}$ and $\mathrm{C}$ fluxes . . . . . . . . . . . . . . . 32

D.4 Development rates of apterous aphids . . . . . . . . . . . 33

D.4.1 Survival . . . . . . . . . . . . . . . . . . 34

D.5 Juvenile apterous (wingless) aphids . . . . . . . . . . . . . . . 34

D.5.1 Inputs: juvenile apterous (wingless) aphids . . . . . . . . . . . . 34

D.5.2 Outputs: juvenile apterous (wingless) aphids . . . . . . . . . 35

D.5.3 Differential equations: juvenile apterous (wingless) aphids . . . . 36

D.5.4 Nitrogen and carbon fluxes for the four apterous instar pools . . 36

D.6 Alate (winged) adult aphids, $\boldsymbol{a}_{\text {laa }} \ldots \ldots \ldots \ldots$. . . . . . . . . . . . . . . 37

D.6.1 Inputs: alate (winged) adult aphids . . . . . . . . . . . . . 37

D.6.2 Outputs: alate (winged) adult aphids . . . . . . . . . . 37

D.6.3 Differential equation: alate (winged) adult aphids . . . . . . . . . 38

D.7 Alate aphid fecundity . . . . . . . . . . . . . . . . . . . . 39

D.8 Alate:apterous ratio in offspring from alate adults . . . . . . . . . . . 40

D.8.1 Total fecundity and fractional fecundity of alate adults . . . . . . 40

D.8.2 Associated $\mathrm{N}$ and $\mathrm{C}$ fluxes . . . . . . . . . . . . . . . . 40

D.9 Development rates of alate aphids . . . . . . . . . . . . . . 41

D.10 Juvenile alate (winged) aphids . . . . . . . . . . . . . . . 41

D.10.1 Inputs: juvenile alate (winged) aphids . . . . . . . . . . . . . 41

D.10.2 Outputs: juvenile alate (winged) aphids . . . . . . . . . . . . 42

D.10.3 Differential equations: juvenile alate (winged) aphids . . . . . . . 42

D.10.4 Nitrogen and carbon fluxes for the four alate instar pools . . . . 43

D.11 Aphid mortality, emigration and fecundity . . . . . . . . . . . . . . . 44

D.11.1 Mortality . . . . . . . . . . . . . . . . . . . 44

D.11.2 Emigration . . . . . . . . . . . . . . . . . 44

D.11.3 Fecundity . . . . . . . . . . . . . . . . . . . 45

D.11.4 Total aphid number per stem, $\boldsymbol{a}_{\mathrm{ph}} \ldots \ldots \ldots \ldots \ldots$

D.12 Aphid sub-model $-\mathrm{C}$ and $\mathrm{N}$ balances . . . . . . . . . . . . . 45

D.12.1 Carbon inputs: phloem, immigration . . . . . . . . . . . 46

D.12.2 Carbon outputs: respiration, honeydew, mortality, emigration,

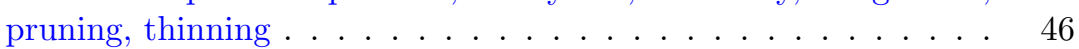

D.12.3 Carbon balance . . . . . . . . . . . . . . . . . . . . 47

D.12.4 Nitrogen inputs: phloem, immigration . . . . . . . . . . . 47

D.12.5 Nitrogen outputs: mortality, emigration, pruning, thinning . . . 48

D.12.6 N balance . . . . . . . . . . . . . . . . . . . . . 48

D.13 Soil sub-model inputs from: mortality, pruning and thinning . . . . . . 49 
D.14 Aphid $\mathrm{C}$ and $\mathrm{N}$ at the end of a rotation . . . . . . . . . . 49

The aphid submodel is shown schematically in Fig 2. The model has 10 state variables. ${ }^{434}$ There are two morphs of the aphid: alate (winged; ala) and aperterous (wingless, apt). Each morph has four juvenile stages called instars, and an adult stage. All aphid state variables have units of numbers of aphids per stem. All notation is summarized in Appendix E.

We define the total number of alate instars $\left(a_{\text {lai }}\right)$, alate adults $\left(a_{\text {laa }}\right)$, the total alates $\left(a_{\mathrm{la}}\right)$, the same for apterous aphids $\left(a_{\mathrm{pti}}, a_{\mathrm{pta}}, a_{\mathrm{pt}}\right)$ and the total number of aphids $\left(a_{\mathrm{ph}}\right)$ as:

$$
\begin{aligned}
a_{\mathrm{lai}} & =a_{\mathrm{la} 1}+a_{\mathrm{la} 2}+a_{\mathrm{la} 3}+a_{\mathrm{la} 4}, \\
a_{\mathrm{la}} & =a_{\mathrm{lai}}+a_{\mathrm{laa}}, \\
a_{\mathrm{pti}} & =a_{\mathrm{pt} 1}+a_{\mathrm{pt} 2}+a_{\mathrm{pt} 3}+a_{\mathrm{pt} 4}, \\
a_{\mathrm{pt}} & =a_{\mathrm{pti}}+a_{\mathrm{pta}}, \\
a_{\mathrm{ph}} & =a_{\mathrm{al}}+a_{\mathrm{pt}} .
\end{aligned}
$$

At $t=0, a_{\mathrm{ph}}=10$ aphids per stem.

The spruce aphid does not colonize and feed on the current year's foliage [90]. From the four foliage categories in the efm, only the last three are used here for the calculation of aphid densities on foliage $\left(A_{\text {leaf,aph }}\right)$. Dividing by the colonized leaf area per stem, $A_{\text {leaf,aph }}\left(\mathrm{m}^{2}\right.$ stem $\left.^{-1}\right)$, aphid density $(\rho)$ per unit area of foliage (aphids $\left.\mathrm{m}^{-2}\right)$ are:

$$
\begin{aligned}
A_{\text {leaf }, \text { aph }} & =A_{\text {leaf }, 2}+A_{\text {leaf }, 3}+A_{\text {leaf }, 4}, \\
\rho_{\text {aph }} & =\frac{a_{\mathrm{ph}}}{A_{\text {leaf }, \text { aph }}} .
\end{aligned}
$$

At $t=0, A_{\text {leaf,aph }}=0.009\left(\mathrm{~m}^{2}\right.$ stem $\left.^{-1}\right)$, and $\rho=10 / 0.009=1111.1$ aphids $\left(\mathrm{m}^{2} \text { leaf }\right)^{-1}$. The $t=0$ values are for young seedlings [Eq (1)] and the 'standard' aphid infestation, $\mathrm{Eq}(64)$ and for the plantation defined in Section 4.2 above. Note that an aphid density of 1000 aphids $\left(\mathrm{m}^{2} \text { leaf }\right)^{-1}$ corresponds to a distance between aphids of about $3 \mathrm{~cm}$.

Using the aphid state variables, the $\mathrm{C}$ and $\mathrm{N}$ contents of the aphids per stem are (units: $\mathrm{kg}$ aphid $\mathrm{C}, \mathrm{N}$ stem $^{-1}$ ):

$$
\begin{aligned}
& C_{\mathrm{ala}}=a_{\mathrm{la} 1} M_{\mathrm{Cala} 1}+a_{\mathrm{la} 2} M_{\mathrm{Cala} 2}+a_{\mathrm{la} 3} M_{\mathrm{Cala} 3}+a_{\mathrm{la} 3} M_{\mathrm{Cala} 4}+a_{\mathrm{laa}} M_{\mathrm{Calaa}}, \\
& N_{\mathrm{ala}}=a_{\mathrm{la} 1} M_{\mathrm{Nala} 1}+a_{\mathrm{la} 2} M_{\mathrm{Nala} 2}+a_{\mathrm{la} 3} M_{\mathrm{Nala} 3}+a_{\mathrm{la} 4} M_{\mathrm{Nala} 4}+a_{\mathrm{laa}} M_{\mathrm{Nalaa}}, \\
& C_{\mathrm{apt}}=a_{\mathrm{pt} 1} M_{\mathrm{Cala} 1}+a_{\mathrm{pt} 2} M_{\mathrm{Cala} 2}+a_{\mathrm{pt} 3} M_{\mathrm{Cala} 3}+a_{\mathrm{pt} 4} M_{\mathrm{Cala} 4}+a_{\mathrm{pta}} M_{\mathrm{Calaa}}, \\
& N_{\mathrm{apt}}=a_{\mathrm{pt} 1} M_{\mathrm{Nala} 1}+a_{\mathrm{pt} 2} M_{\mathrm{Nala} 2}+a_{\mathrm{pt} 3} M_{\mathrm{Nala} 3}+a_{\mathrm{pt} 4} M_{\mathrm{Nala} 4}+a_{\mathrm{pta}} M_{\mathrm{Nalaa}}, \\
& C_{\mathrm{aph}}=C_{\mathrm{ala}}+C_{\mathrm{apt}}, \\
& N_{\mathrm{aph}}=N_{\mathrm{ala}}+N_{\mathrm{apt}} .
\end{aligned}
$$

The $\mathrm{C}$ and $\mathrm{N}$ contents of each morphological aphid form (Fig 2) are constants, unaffected by growth temperature or nutritional status and are (units: $\mathrm{kg} \mathrm{C}, \mathrm{N}$ 
$\left.\operatorname{aphid}^{-1}\right)$ :

$$
\begin{aligned}
& M_{\text {Cala } 1}=M_{\text {Nala1 }}=1 \times 10^{-6}, \\
& M_{\text {Cala } 2}=M_{\text {Nala } 2}=2 \times 10^{-6}, \\
& M_{\text {Cala } 3}=M_{\text {Nala3 }}=3 \times 10^{-6}, \\
& M_{\text {Cala4 }}=M_{\text {Nala4 }}=4 \times 10^{-6}, \\
& M_{\text {Calaa }}=M_{\text {Nalaa }}=5 \times 10^{-6}, \\
& M_{\text {Capt1 }}=M_{\text {Napt1 }}=1 \times 10^{-6}, \\
& M_{\text {Capt } 2}=M_{\text {Napt2 }}=2 \times 10^{-6}, \\
& M_{\text {Capt3 }}=M_{\text {Napt3 }}=3 \times 10^{-6}, \\
& M_{\text {Capt } 4}=M_{\text {Napt4 }}=4 \times 10^{-6}, \\
& M_{\text {Capta }}=M_{\text {Napta }}=5 \times 10^{-6} .
\end{aligned}
$$

These estimates were made to enable the model to be completed, although we have been unable to find measurements of these quantities. The values are not critical for the range of behaviour exhibited by the model (See chapter 4 of Dixon [4] and particularly figure 4.1 on p. 59 ; note that $\left.1 \times 10^{-6} \mathrm{~kg}=1 \mathrm{mg}=1000 \mu \mathrm{g}\right)$.

\section{D.1 Apterous (wingless) adult aphids, $a_{\text {pta }}$}

\section{D.1.1 Inputs: apterous (wingless) adult aphids}

There is a single input, from the developmental output flux of the fourth apterous instar $\left(a_{\mathrm{pt} 4}\right.$, Fig 2), $O_{\mathrm{apt} 4 \rightarrow \mathrm{a}}$, calculated in Eq (42) (the output is assumed to become an input without loss). The input, $I_{\text {apta }}$, requires $\mathrm{C}$ and $\mathrm{N}$ fluxes, of $I_{\mathrm{Capt} 4 \rightarrow \mathrm{a}}$ and $I_{\mathrm{Napt} 4 \rightarrow \mathrm{a}}$ :

$$
\begin{aligned}
I_{\text {apta }} & =O_{\text {apt } 4 \rightarrow \mathrm{a}}, \text { and } \\
I_{\text {Capt } 4 \rightarrow \mathrm{a}} & =I_{\text {apta }} M_{\text {Capta }}, \quad I_{\text {Napt } 4 \rightarrow \mathrm{a}}=I_{\text {apta }} M_{\text {Napta }} .
\end{aligned}
$$

Units of the first of Eq (8) are aphids stem ${ }^{-1} \mathrm{~d}^{-1}$ and of the other two are $\mathrm{kg}$ aphid C, $\mathrm{N}$ stem ${ }^{-1} \mathrm{~d}^{-1}$. See Eq (7) for the C, N contents of apterous adults.

\section{D.1.2 Outputs: apterous (wingless) adult aphids}

It is assumed that there is no flux of aphids to surface litter accompanying foliage litter flux. Thinning, as applied in 'plantation' mode [Section 4.2, Eq (1)] - i.e. removal of whole trees (stems), does not affect aphid state variables which are aphids per stem (although aphid number per unit ground area is affected). This leaves two outputs: mortality (dependent on temperature and nutrition) and pruning (removing branches including foliage).

Mortality. Our approach to aphid mortality is mostly guess work, as there is little guidance on the topic which is relevant to a mechanistic modelling exercise where ordinary differential equations are the basic representational tool. Some authors prefer to talk of 'survival' (e.g. Duffy et al., 2017 [63]; see their figure 3), but survival then depends on a development rate (Section D.4) as well as a mortality rate. Dixon ([4], p. 165, see their figure 7.25) presents mortality rate as related to relative growth rate, without specifying units, rather than relating mortality rate to forest sub-model variables (such as phloem $\mathrm{N}$ ) and driving variables (such as air temperature). We ignore 
any possible influence of predators on mortality. There is some evidence from other mechanistic aphid modelling that considering predation does not fundamentally effect the conclusions regarding the impacts of climatic change [29].

It is assumed that aphid mortality, $k_{\text {aph,mort }}$, depends on air temperature, $T_{\text {air }}$ and phloem N, $N_{\text {phloem }}$; the specific rates $\left(\mathrm{d}^{-1}\right)$ are calculated independently [Eqs (9) and (10)] and then combined in Eq (11). Adult apterous mortality rate is then $O_{\text {apta } \rightarrow \text { mort }}$ (aphids stem ${ }^{-1} \mathrm{~d}^{-1}$ ), given by Eq (12).

The specific air-temperature-dependent mortality rate, $k_{\text {aph,Tmort }}\left(\mathrm{d}^{-1}\right)$, is given by a skewed inverted parabola (Fig D.1):

$$
\begin{aligned}
& k_{\text {aph,Tmort }}=\left[k_{\text {aph,Tmort,opt }}+\left(k_{\text {aph,Tmort }, 0}-k_{\text {aph,Tmort,opt }}\right)\right. \\
& \left.\times \frac{\left(T_{\text {air }}-T_{\text {aph,mort,opt }}\right)^{2}}{\left(T_{\text {aph,mort }, 0}-T_{\text {aph,mort }, \text { opt }}\right)^{2}}\right] \\
& \times\left[1+c_{\text {aph,mort,skew }}\left(\frac{T_{\text {air }}-T_{\text {aph,mort,opt }}}{T_{\text {aph,mort }, \text { opt }}-T_{\text {aph }, \text { mort }, 0}}\right)\right] . \\
& T_{\text {aph }, \text { mort }, 0}=0, \quad T_{\text {aph }, \text { mort }, \text { opt }}=15^{\circ} \mathrm{C} \text {; } \\
& k_{\text {aph }, \text { Tmort }, 0}=0.04, \quad k_{\text {aph }, \text { Tmort }, \text { opt }}=0 \mathrm{~d}^{-1}, \quad c_{\text {aph, } \text { mort, }, \text { kkew }}=0.2
\end{aligned}
$$

If air temperature $T_{\text {air }}$ equals the optimum temperature for minimum aphid mortality, $T_{\text {aph,mort,opt }}$, then mortality rate $k_{\text {aph,Tmort }}=k_{\text {aph,Tmort,opt }}$ is zero. If temperature $T_{\text {air }}=T_{\text {aph,mort }, 0}$ (the second reference point, taken here to be $0{ }^{\circ} \mathrm{C}$ ), then $k_{\text {aph }, \text { Tmort }}=k_{\text {aph }, \text { Tmort }, 0}=4 \% \mathrm{~d}^{-1}$. The second term in square brackets skews the response about the optimum temperature (here $15{ }^{\circ} \mathrm{C}$ ), according to the value of the skewness parameter $c_{\text {aph,mort,skew }}$. With the value given, if $T_{\text {air }}=T_{\text {aph,mort, } 0}$, then the mortality rate is decreased by $20 \%$. The temperature response of mortality rate is drawn in Fig D.1 for several values of the skewness parameter.

Fig D.1. Aphid mortality rate as affected by temperature. Eq (9) is plotted

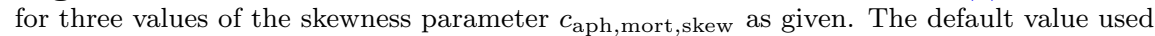
in the simulations is 0.2 , shown by the dark line. Other parameters are as in Eq (9). Go to figure.

The most significant part of the response drawn in Fig D.1 is the increase in mortality as the temperature is lowered. This causes the aphid infestation to become less severe or even zero as the temperature is lowered (Fig 4).

Nutrition-dependent mortality rate, $k_{\text {aph,Nmort }}\left(\mathrm{d}^{-1}\right)$, is described by a 'switch-off' sigmoidal response (e.g. [37], equation 4.61, figure 4.9, pp. 109-111), to phloem N concentration, $N_{\text {phloem }}[\mathrm{Eq}(2)$, Fig D.2], given by

$$
\begin{aligned}
& k_{\text {aph,Nmort }}=k_{\text {aph,Nmort,max }} \frac{\left(K_{\text {Naph,mort }}\right)^{q_{\text {aph }, \text { Nmort }}}}{\left(K_{\text {Naph,mort }}\right)^{q_{\text {aph }, \text { Nmort }}}+\left(N_{\text {phloem }}\right)^{q_{\text {aph }, \text { Nmort }}}} . \\
& k_{\text {aph,Nmort,max }}=0.1 \mathrm{~d}^{-1}, K_{\text {Naph,mort }}=1 \mathrm{~kg} \mathrm{~N} \mathrm{~m}^{-3}, \quad q_{\text {aph,Nmort }}=2 .
\end{aligned}
$$

The maximum mortality rate, $k_{\text {aph,Nmort,max }}$, if there is no food $\left(N_{\text {phloem }}=0\right)$ is $10 \%$ per day. The half-maximal mortality rate ( $5 \%$ per day) occurs when $N_{\text {phloem }}=K_{\text {Naph,mort }}=1 \mathrm{~kg} \mathrm{~N} \mathrm{~m}^{-3}=1 / 14 \mathrm{~mol} \mathrm{~N}$. Note that, from Eq (2), this corresponds to a foliage substrate $\mathrm{N}$ concentration of $N_{\mathrm{le}}=0.01 \mathrm{~kg}$ substrate $\mathrm{N}(\mathrm{kg}$ 
structural dry matter $)^{-1}$. The nutritionally-dependent mortality rate approaches zero at high values of $N_{\text {phloem }}$. The steepness of the response depends on $q_{\text {aph,Nmort }}$, here assigned the value 2. The response is drawn in Fig D.2 for four values of $q_{\text {aph,Nmort }}$.

Fig D.2. Nutritional response of aphid mortality. Aphid mortality rate as affected by $\mathrm{N}$ nutrition, in particular, N concentration in the phloem, $N_{\text {phloem }}$ [Eq (2)]. $\mathrm{Eq}(10)$ is plotted for four values of the steepness parameter, $q_{\mathrm{aph}, \mathrm{Nmort}}$, as given. The default value used in the simulations is $q_{\mathrm{aph}, \mathrm{Nmort}}=2$. Go to figure.

It is assumed that the overall mortality rate $\left(\mathrm{d}^{-1}\right), k_{\text {aph,mort }}$, is given by summing the temperature-dependent and the nutritionally-dependent mortality rates [Eqs (9) and (10); assuming aphid temperature $=$ air temperature, $\left.T_{\text {air }}\left({ }^{\circ} \mathrm{C}\right)\right]$. Therefore:

$$
k_{\mathrm{aph}, \text { mort }}=k_{\mathrm{aph}, \mathrm{Tmort}}+k_{\mathrm{aph}, \mathrm{Nmort}}
$$

The mortality rate varies between $2 \%$ and $6 \%$ per day, depending on temperature and $\mathrm{N}$ nutrition (Fig D.3B).

We have mentioned above (Section D.1.2), our difficulties with mortality rate. We use the same mortality rate, $k_{\mathrm{aph} \text {,mort }}$ [Eq (11)], for all the aphid state variables (Fig 2), although this could be easily relaxed. In Fig D.3, the components of mortality are examined. Mortality rate can be calculated in the absence of aphids, although the presence and activity of aphids depresses phloem N (Fig D.3D) and this increases $\mathrm{N}$ phloem-dependent mortality $\left[k_{\text {aph,Nmort }}\right.$, Fig D.3C, Fig D.2, Eq (10)].

Temperature-dependent mortality, $k_{\text {aph,Tmort }}$, is the same whether aphids whether aphids are present or not [Fig D.3C, Eq (9)]. Fig D.3A shows the effect of aphids on leaf area index $[\mathrm{Eq}(1)]$ at a constant stem density, nstems, [Eq (1)]. Later, after considering developmental rates (Section D.4), we examine survival in Section D.4.1 and Fig D.8.

Fig D.3. Aphid mortality.. Contributions to aphid mortality are shown over 12 months without aphids being present (dash-dot lines) and with aphid infection at $t=0$ (solid lines) of 10 adult alates per stem [Eq (64)]. At $t=0 \mathrm{~d}$ the seedling plants have an

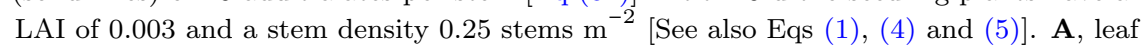
area index, $L_{\mathrm{AI}}[\mathrm{Eq}(1)] . \mathbf{B}$, total aphids, $a_{\mathrm{ph}}$ [Eq (4)]; aphid mortality rate, $k_{\mathrm{aph}, \mathrm{mort}}$ [Eq (11)]. C, temperature-dependent mortality, $k_{\text {aph,Tmort }}[\mathrm{Eq}(9)]$; nitrogen-dependent mortality, kaph,Nmort $[\mathrm{Eq}(10)]$. D, Air temperature, $T_{\text {air }}$ (Fig 3), the determinant of temperature-dependent mortality in $\mathbf{C}$; phloem $\mathrm{N}$ [Eq (2)], the determinant of nutrition-dependent mortality in $\mathbf{C}$, phloem $\mathrm{N}$ is decreased by aphid infestation (solid line). Go to figure.

With Eq (11) for specific aphid mortality rate, $k_{\text {aph,mort }}\left(\mathrm{d}^{-1}\right)$, output from the apterous adult pool, $a_{\mathrm{pta}}$, to mortality is (aphids stem ${ }^{-1} \mathrm{~d}^{-1}$ )

$$
O_{\text {apta } \rightarrow \text { mort }}=k_{\text {aph,mort }} a_{\text {pta }} .
$$

There are output $(O) \mathrm{C}$ and $\mathrm{N}$ fluxes associated with this aphid flux (using an obvious notation):

$$
O_{\text {Capta } \rightarrow \text { mort }}=O_{\text {apta } \rightarrow \text { mort }} M_{\text {Capta }}, \quad O_{\text {Napta } \rightarrow \text { mort }}=O_{\text {apta } \rightarrow \text { mort }} M_{\text {Napta }} .
$$

Units are $\mathrm{kg} \mathrm{C}, \mathrm{N}$ stem ${ }^{-1} \mathrm{~d}^{-1}$. Aphid $\mathrm{C}$ and $\mathrm{N}$ contents are given in $\mathrm{Eq}$ (7). These fluxes are input to the soil surface litter pools [Eqs (108) and (118)]. 
Pruning. The pruning flux of apterous adults is $O_{\text {apta } \rightarrow \text { prune }}\left(\right.$ aphids stem $\left.{ }^{-1} \mathrm{~d}^{-1}\right) . \quad{ }_{533}$ Foliage pruning, if applied, occurs at a rate of $k_{\mathrm{le} \rightarrow \text { prune }}\left(\mathrm{d}^{-1}\right)$. This gives rise to outputs (losses) of aphids and associated fluxes of $\mathrm{C}$ and $\mathrm{N}$ ( $\mathrm{kg}$ aphid $\left.\mathrm{C}, \mathrm{N} \mathrm{stem}{ }^{-1} \mathrm{~d}^{-1}\right)$, of

$$
\begin{aligned}
& O_{\text {apta } \rightarrow \text { prune }}=k_{\text {le } \rightarrow \text { prune }} a_{\text {apta }} \\
& O_{\text {Capta } \rightarrow \text { prune }}=O_{\text {apta } \rightarrow \text { prune }} M_{\text {Capta }}, \quad O_{\text {Nata } \rightarrow \text { prune }}=O_{\text {apta } \rightarrow \text { prune }} M_{\text {Napta }}, \\
& k_{\text {le } \rightarrow \text { prune }}=0 \mathrm{~d}^{-1} .
\end{aligned}
$$

The foliage pruning constant, $k_{\mathrm{le} \rightarrow \mathrm{prune}}$, is not used in the simulations presented here and it is set to zero. This aphid output flux is added to the mortality flux in Eq (15).

The total output of adult apterous aphids, $O_{\text {apta }}$, is obtained by adding the contributions from mortality [Eq (12)] and pruning [Eq (14)]:

$$
O_{\text {apta }}=O_{\text {apta } \rightarrow \text { mort }}+O_{\text {apta } \rightarrow \text { prune }} .
$$

\section{D.1.3 Differential equation: apterous (wingless) adult aphids}

The differential equation (apterous aphids stem ${ }^{-1} \mathrm{~d}^{-1}$ ) and initial value for the state variable, $a_{\text {pta }}$, for the apterous adult aphids is:

$$
\begin{aligned}
& \frac{d a_{\mathrm{pta}}}{\mathrm{d} t}=I_{\mathrm{apta}}-O_{\mathrm{apta}}, \\
& a_{\mathrm{pta}}(t=0)=0 \text { apterous adults stem }{ }^{-1} .
\end{aligned}
$$

The input and output terms are given by Eqs (43) and (15).

\section{D.2 Apterous aphid fecundity}

Adult aphids give birth to offspring or nymphs. The rate at which this occurs is influenced by temperature and phloem $\mathrm{N}$ concentration. The $\mathrm{N}$ ingested is entirely converted to wingless (apt) and winged (ala) 1st instar nymphs, $a_{\mathrm{pt1}}$ and $a_{\mathrm{la} 1}$ (Fig 2). These can have different $\mathrm{N}$ contents [Eq (7)]. Account must be taken of this before total and fractional fecundities can be calculated [Section D.3.4; Eq (29)].

\section{D.2.1 Apterous aphid fecundity as a function of temperature}

A general and easily adjustable temperature response function, $f(T)$, used for many plant and soil biological processes is ([37], pp. 105-106)

$$
\begin{aligned}
f(T) & =\frac{\left(T-T_{0}\right)^{q_{1}}\left(T_{0}^{\prime}-T\right)^{q_{2}}}{\left(T_{\text {ref }}-T_{0}\right)\left(T_{0}^{\prime}-T_{\text {ref }}\right)^{q_{2}}} \text { for } T_{0}<T<T_{0}^{\prime}, \text { else } 0 . \\
q_{1} & =2, q_{2}=1, T_{0}=0{ }^{\circ} \mathrm{C}, T_{\text {ref }}=20^{\circ} \mathrm{C}, T_{0}^{\prime}=45^{\circ} \mathrm{C}, \\
T_{\text {max }} & =\frac{q_{1} T_{0}^{\prime}+q_{2} T_{0}}{q_{1}+q_{2}}=30^{\circ} \mathrm{C} .
\end{aligned}
$$

Here default values of the five parameters are given; the shape of the default response is illustrated by the continuous lines in Fig D.4A-D. The default is a cubic. $f(T)$ is only non zero between temperatures $T_{0}$ and $T_{0}^{\prime}$. Fig D.4A shows the effect of varying the parameter $q_{1}$. The response is initially sigmoidal if $q_{1}>1$. In Fig D. $4 \mathrm{~B}, q_{2}$ is varied. It can be seen that the steepness of the high-temperature decrease is highly dependent on $q_{2}$ for $q_{2}<1$, although the early part of the curve is much less affected by $q_{2}$. In

Fig D.4C, $T_{0}$ is varied and in Fig D.4D, $T_{0}^{\prime} . T_{\text {ref }}$ is a reference temperature: $f(T)=1$ at $T=T_{\text {ref }}=20{ }^{\circ} \mathrm{C}$. The five parameters define: the zero points of $f(T)\left(T_{0}\right.$ and $\left.T_{0}^{\prime}\right)$; the 
shape of the curve in the neighbourhood of the zero points $\left(q_{1}\right.$ and $\left.q_{2}\right)$; and the reference temperature, $T_{\text {ref }}$. An equation for the temperature where $f(T)$ is maximum is given, $T_{\max }$; the temperature of any point of inflexion can be derived.

Fig D.4. General biological temperature function. General biological temperature function, Eq (17), with five parameters: $q_{1}, q_{2}, T_{0}, T_{0}^{\prime}$ and $T_{\text {ref }}$, of which four are varied in the figure. This is applied in the efm and the aphid sub-model for various processes. It is drawn, in A for three values of parameter $q_{1}$, in B for three values of $q_{2}$, in $\mathrm{C}$ for three values of $T_{0}$ and in $\mathrm{D}$ for three values of $T_{0}^{\prime}$. Otherwise, the parameters have the values given in Eq (17). Commonly used default values are shown by the continuous heavy lines. Go to figure.

Taking $T=T_{\text {air }}$ and with the default parameters given, Eq (17) is used to modify many above-ground (shoot) plant processes (where it is reasonable to take shoot temperature equal to air temperature, $T_{\text {air }}$ ), as well as the temperature dependence assumed for some aphid processes, e.g. emigration [Eq (61)].

The effect of temperature on aphid fecundity, $f_{\text {Taph,fec }}$, is obtained by using air temperature, $T_{\text {air }}$ and the standard temperature function in Eq (17) and Fig D.4, but with two different temperature parameters $\left(T_{0}, T_{0}^{\prime}\right)$ :

$$
f_{\text {Taph,fec }}\left(T=T_{\text {air }}\right)=f\left(T_{\text {air }}, T_{0}=T_{0 \text { aph,fec }}=3, T_{0}^{\prime}=T_{0, \text { aph,fec }}^{\prime}=30^{\circ} \mathrm{C}\right) .
$$

This is drawn in Fig D.5A. It can be compared with Duffy et al.'s [63] figure 2, who make use of data from Dean [91], although our calculations of total and fractional fecundities are completed below [Section D.3.4, Eq (29)].

\section{D.2.2 Apterous aphid fecundity as a function of phloem $\mathrm{N}$ concentration}

Aphids are assumed to have a maximum volume intake of phloem sap at a given temperature, $v_{\text {apta,max }}\left(\mathrm{m}^{3}\right.$ aphid $\left.{ }^{-1} \mathrm{~d}^{-1}\right)$, obtained by $f_{\text {Taph,fec }}\left(T_{\text {air }}\right)$ of Eq (18)

(Fig D.5A) multiplied by the maximum volume intake at the reference temperature of $20{ }^{\circ} \mathrm{C}$ :

$$
v_{\text {apta,max }}=\left(f_{\text {Taph,fec }}\right)\left(v_{\text {apta, } \max 20}\right), v_{\text {apta, } \max 20}=0.2 \times 10^{-6} \mathrm{~m}^{3} \operatorname{aphid}^{-1} \mathrm{~d}^{-1} .
$$

The $20{ }^{\circ} \mathrm{C}$ value, $v_{\text {apta,max20 }}$, corresponds to $0.2 \mathrm{ml} \mathrm{aphid}^{-1} \mathrm{~d}^{-1}$. The maximum phloem-volume limited $\mathrm{N}$ intake per aphid is (units are $\mathrm{kg} \mathrm{N}$ aphid ${ }^{-1} \mathrm{~d}^{-1}$ ) (Fig D.5C):

$$
I_{\text {Nphloem,vapta,max }}=\left(v_{\text {apta,max }}\right)\left(N_{\text {phloem }}\right) \text {. }
$$

$N_{\text {phloem }}$ is given by Eq (2) [ $\mathrm{kg} \mathrm{N}$ substrate in phloem $\left.\left(\mathrm{m}^{3} \text { phloem sap }\right)^{-1}\right]$. This may exceed the $\mathrm{N}$ requirement of the aphid, defined as the maximum amount of $\mathrm{N}$ which can be processed $(p)$ at the ambient temperature $\left(T_{\text {air }}\right)$, calculated by

$$
I_{\text {Npapta,max }}=f_{\text {Taph,fec }}\left(T_{\text {air }}\right) I_{\text {Npapta,max20 }} ; \quad I_{\text {Npapta,max20 }}=2 \times 10^{-6} \mathrm{~kg} \mathrm{~N}_{\text {aphid }^{-1} \mathrm{~d}^{-1} .} \text {. }
$$

$f_{\text {Taph,fec }}\left(T_{\text {air }}\right)$ is given in $\mathrm{Eq}(18) . I_{\mathrm{Npapta}, \max 20}$ is the maximum amount of $\mathrm{N}$ that can be processed $(p)$ at the reference temperature of $20{ }^{\circ} \mathrm{C}$. $I_{\text {Npapta,max }}$ is illustrated in Fig D.5C. Note that here we have used the same temperature dependence, $f_{\text {Taph,fec }}$, for the process-dependence [Eq (21)] as for the volume limitation [Eq (19)].

The actual amount of $\mathrm{N}$ ingested per aphid per $\mathrm{d}$ is the least of the volume-intake-limited N-intake [Eq (20)] or the processing-limited N-intake [Eq (21)] $\left(\mathrm{kg} \mathrm{N}\right.$ aphid $\left.^{-1} \mathrm{~d}^{-1}\right)$ :

$$
I_{\text {phloem } \rightarrow \text { apta,aphid }}=\min \left\{I_{\text {Nphloem, vapta, } \max }, I_{\text {Npapta,max }}\right\} .
$$


Neither of the two arguments is affected by the presence of aphids - e.g. which will depress $N_{\text {phloem }}$ (Fig D.5B). In fact the processing-limited maximum is about eight-times as large as the volume-limited maximum (Fig D.5C), so the volume-limitation wins the argument in $\mathrm{Eq}(22)$.

Dividing by $N_{\text {phloem }}[\mathrm{Eq}(2)]$, Fig D.5B] $\left(\mathrm{kg} \mathrm{N} \mathrm{m}^{-3}\right)$, which is affected by the aphid infestation, the actual volume of phloem sap ingested per apterous adult aphid is $\left(\mathrm{m}^{3}\right.$ $\left.\operatorname{aphid}^{-1} \mathrm{~d}^{-1}\right)$ :

$$
v_{\text {phloem } \rightarrow \text { apta }}=\frac{I_{\text {Nphloem } \rightarrow \text { apta, aphid }}}{N_{\text {phloem }}} .
$$

This is illustrated in Fig D.5B and Fig D.5D.

The $\mathrm{C}$ intake per aphid $\left(\mathrm{kg} \mathrm{C}\right.$ aphid $\left.{ }^{-1} \mathrm{~d}^{-1}\right)$ and the $\mathrm{N}$ and $\mathrm{C}$ intakes per stem $(\mathrm{kg} \mathrm{N}$, $\mathrm{C}$ stem $^{-1} \mathrm{~d}^{-1}$ ) are respectively:

$$
\begin{aligned}
I_{\text {Cphloem } \rightarrow \text { apta }, \text { aphid }} & =v_{\text {phloem } \rightarrow \text { apta }} C_{\text {phloem }}, \\
I_{\text {Nphloem } \rightarrow \text { apta }} & =a_{\text {pta }} I_{\text {Nphloem } \rightarrow \text { apta,aphid }}, \\
I_{\text {Cphloem } \rightarrow \text { apta }} & =a_{\text {pta }} I_{\text {Cphloem } \rightarrow \text { apta }, \text { aphid }}
\end{aligned}
$$

The right side quantities are given in Eqs (23), (2), (16), (22) and the first of (24).

Fig D.5. Elements determining fecundity. Factors contributing to fecundity are shown as they occur in an Eskdalemuir environment (Section 4.1), for the first year of growth of typical spruce plantation (Section 4.2) infected with ten alate adults at time zero $[\mathrm{Eq}(64)]$. A, air temperature, $T_{\text {air }}$, and its effect on fecundity, $f_{\text {Taph,fec }}$ [Eq (18)]. B, phloem N concentration, $N_{\text {phloem }}[\mathrm{Eq}(2)]$ is illustrated without and with aphid infection which lowers $N_{\text {phloem }}$ levels and thereby increases the actual volume of phloem sap ingested, $v_{\text {phloem } \rightarrow \text { apta }}[\mathrm{Eq}(23)]$. C, alternatives for the $\mathrm{N}$ ingested per aphid per day: (i) process-limited $(p) \mathrm{N}$ intake, $I_{\text {Npapta,max }}[\mathrm{Eq}(21)]$; (ii) phloem-volume-limited $(v) \mathrm{N}$ intake, $I_{\mathrm{Nphloem}, \text { vapta,max }}[\mathrm{Eq}(20)]$. D, actual phloem volume ingested per aphid per day, $v_{\text {phloem } \rightarrow \text { apta }}[\mathrm{Eq}(23)]$. Go to figure.

\section{D.3 Alate:apterous ratio in offspring from apterous adults}

The $\mathrm{N}$ ingested is assumed to be completely converted to wingless (apt) and winged (ala) first instar nymphs, in pools $a_{\mathrm{pt} 1}$ and $a_{\mathrm{la} 1}$ (Fig 2). Because these two forms can have different masses ( $\mathrm{N}$ contents) [Eq (7)], the fractions of each type must first be calculated before total fecundity can be determined (Section D.3.4). It is assumed that the ratio is affected by three factors: temperature, total aphid density and nutritional status [92]. It is assumed that the three factors operate multiplicatively and for each factor $\mathrm{x}$, the fraction of the offspring of apterous female adults which are alate (winged), $f_{\mathrm{x}, \mathrm{apt} \rightarrow \mathrm{ala}}$, is calculated. The possible effects of day length are ignored (but see figure 6.8, p. 109 in [4]). Duffy et al. ([63], equation 4) assume the percentage of nymphs which are alates increases with aphid density and also growth stage of the cereal crop.

\section{D.3.1 Alate:apterous ratio as a function of temperature}

Higher air temperatures, $T_{\text {air }}\left({ }^{\circ} \mathrm{C}\right)$, generally give more alates ([4], page 109). A positive (switch-on) sigmoidal dependence on air temperature $\left(T_{\text {air }}\right)$ is assumed ([37], pp. 109 110), with:

$$
f_{\text {Tapta } \rightarrow \text { ala } 1}=\frac{T_{\text {air }}^{q_{\text {Tapt }}}}{T_{\text {air }}^{q_{\text {Tapt }}}+K_{\text {Tapt }}}, \quad q_{\text {Tapt }}=2, K_{\text {Tapt }}=10{ }^{\circ} \mathrm{C} .
$$


This is drawn in Fig D.6. $K_{\text {Tapt }}$ is the half-maximal response temperature. $q_{\text {Tapt }}$ determines the steepness of the response; $q_{\text {Tapt }}=1$ gives the familiar Michaelis-Menten response.

\section{D.3.2 Alate:apterous ratio as a function of aphid total density}

This is $\rho_{\text {aph }}$ [aphids $\left(\mathrm{m}^{2} \text { leaf area }\right)^{-1}$ ], Eq (5). Higher aphid densities cause more of the apterous offspring to be alates (winged). As in Eq (25) and Fig D.6 above for relative air temperature, a positive sigmoidal dependence on aphid density, $\rho_{\text {aph }}$, is assumed:

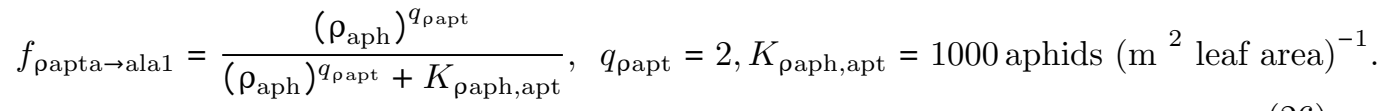

The half-maximum density point is where $\rho_{\text {aph }}=K_{\rho \text { aph,apt }}$; the value given is equivalent to aphids being on a square grid $3 \mathrm{~cm}$ apart and is of the same order as the annual peak in $\rho_{\text {aph }}$.

Fig D.6. Alate fraction of apterous offspring as affected by temperature. Eq (25) is drawn for four values of the $q$ parameter. The default value used in the simulations is $q=2$. Go to figure.

\section{D.3.3 Alate:apterous ratio as a function of nutritional status}

In this case, good nutritional status [a high value of $N_{\text {phloem }}, \mathrm{Eq}(2)$ ] gives few alates and the alate fraction approaches zero for high values of $N_{\text {phloem }}$. Low nutritional status and a low $N_{\text {phloem }}$ causes the alate fraction $f_{\text {Napta } \rightarrow \text { ala1 }}$ to approach unity. An expression similar to that used in Fig D.2 for aphid mortality is employed [a 'switch-off' sigmoid rather than the 'switch-on' sigmoid used in Eq (26) and Eq (25); Fig D.6] ([37], figure 4.9, p. 111):

$$
f_{\text {Napta } \rightarrow \text { ala } 1}=\frac{\left(K_{\text {Napt }}\right)^{q_{\text {Napt }}}}{\left(K_{\text {Napt }}\right)^{q_{\text {Napt }}}+N_{\text {phloem }}}, \quad q_{\text {Napt }}=2, K_{\text {Napt }} \mathrm{kg} \mathrm{N} \mathrm{m}^{-3} .
$$

The half-maximal phloem $\mathrm{N}$ concentration of $K_{\mathrm{Napt}}=4 \mathrm{~kg} \mathrm{~N} \mathrm{~m}^{-3}$ is equivalent to a foliage $\mathrm{N}$ substrate concentration of $N_{\mathrm{le}}=0.04 \mathrm{~kg} \mathrm{~N}$ substrate ( $\mathrm{kg}$ structural dry matter $)^{-1}[\mathrm{Eq}(2)]$.

Combining these three factors multiplicatively [Eqs (25), (26) and (27)], therefore the fraction of offspring from apterous adults which are alate (winged) and are apterous are given by:

$$
\begin{aligned}
f_{\text {apta } \rightarrow \text { ala } 1} & =f_{\text {Tapta } \rightarrow \text { ala } 1} f_{\text {papta } \rightarrow \text { ala } 1} f_{\text {Napta } \rightarrow \text { ala } 1} \\
f_{\text {apta } \rightarrow \text { apt1 }} & =1-f_{\text {apta } \rightarrow \text { ala } 1}
\end{aligned}
$$

These three components and the outcome for $f_{\text {apta } \rightarrow \text { ala1 }}$ are illustrated in Fig D.7.

The relative contributions to the fraction of apterous offspring assigned to the alate pathway are shown in Fig D.7 [Fig 2, Eq (28)]. In Fig D.7A, with dependence on air temperature, $T_{\text {air }}$, this fraction, $f_{\text {Tapta } \rightarrow \text { ala1 }}[\mathrm{Eq}(25)]$ is not affected by the presence of aphids. In Fig D.7B, showing dependence on aphid density, $\rho_{\text {aph }}$, the fraction is zero in the absence of aphids [Eq (26), with $\left.\rho_{\text {aph }}=0\right]$. The dependence on phloem N, $N_{\text {phloem }}$, is illustrated in Fig D.7C [Eq (27)]. Because phloem $\mathrm{N}$ is consumed by aphids, their presence lowers $N_{\text {phloem }}$, giving the lower continuous line for $N_{\text {phloem }}$; this also raises 
the alate fraction of apterous offspring (upper dashed line). Last, in Fig D.7D, the three fractions shown in Fig D.7A-C are multiplied in Eq (28) to give the final allocation fraction, $f_{\text {apta } \rightarrow \text { ala } 1}$.

Fig D.7. Elements contributing to the fraction of apterous offspring which are alates. Illustration of how the three different components contribute to the fraction of apterous offspring which are alates, as in Eq (28). This is for an Eskdalemuir environment (Section 4.1) and the first year of growth of typical spruce plantation (Section 4.2) infected with ten alate adults at time zero [Eq (64)]. A, air temperature, $T_{\text {air }}$, via Eq (25). B, aphid density, $\rho_{\text {aph }}$, via Eq (26). C, phloem N, $N_{\text {phloem }}$, via Eq (27). Here, the introduction of aphids at time zero, depresses $N_{\text {phloem }}$, the lower continuous line, resulting in a higher fraction destined for alates (upper dashed line). D, the three factors shown in $\mathbf{A}, \mathbf{B}, \mathbf{C}$ are combined in Eq (28). Go to figure.

\section{D.3.4 Total fecundity and the fractional fecundity of apterous adults}

Now that we have calculated the fractions of offspring from apterous adults which are alate and which are apterous, $f_{\text {apta } \rightarrow \text { ala1 }}$ and $f_{\text {apta } \rightarrow \text { apt1 }}$ in Eq (28), we are able to calculate the total fecundity of apterous adults. It is assumed that $\mathrm{N}$ ingested by apterous adult females per stem per day, $I_{\text {Nphloem } \rightarrow \text { apta }}[\mathrm{Eq}(24)]$, is converted without loss into first-instar nymphs, giving a total rate of output to first instar offspring of $O_{\text {apta } \rightarrow \text { ala } 1}+O_{\text {apta } \rightarrow \text { apt } 1}$, denoted by $O_{\text {apta } \rightarrow \text { axx } 1}[$ with Eq $(28)]$, of $\left(\right.$ aphids stem ${ }^{-1} \mathrm{~d}^{-1}$ )

$$
\begin{aligned}
O_{\text {apta } \rightarrow \text { axx } 1} & =O_{\text {apta } \rightarrow \text { ala } 1}+O_{\text {apta } \rightarrow \text { apt } 1} \\
& =\frac{I_{\text {Nphloem } \rightarrow \text { apta }}}{f_{\text {apta } \rightarrow \text { apt } 1} M_{\text {Napta } 1}+f_{\text {apta } \rightarrow \text { ala } 1} M_{\text {Nala } 1}}, \\
f_{\text {fecapta }} & =\frac{O_{\text {apta } \rightarrow \text { axx } 1}}{a_{\text {pta }}} .
\end{aligned}
$$

The aphid $\mathrm{N}$ contents are given in Eq (7). Equation (29b) defines the total fractional fecundity of apterous adults, $f_{\text {fecapta }}\left(\mathrm{d}^{-1}\right)$; this is the total output of nymphs from apterous adults $\left(a_{\text {pta }}\right)$ towards the alate and apterous first-instar pools divided by the number of apterous adults $\left(a_{\text {pta }}\right)$. The transfer of nymph outputs into inputs into the first-instar pools is assumed to occur without loss giving (aphids stem ${ }^{-1} \mathrm{~d}^{-1}$ )

$$
\begin{aligned}
O_{\text {apta } \rightarrow \text { apt1 }} & =f_{\text {apta } \rightarrow \text { apt } 1} O_{\text {apta } \rightarrow \text { axx } 1}, \quad O_{\text {apta } \rightarrow \text { ala } 1}=f_{\text {apta } \rightarrow \text { ala } 1} O_{\text {apta } \rightarrow \text { axx } 1}
\end{aligned}
$$

\section{D.3.5 Associated N and C fluxes}

There are output $\mathrm{N}$ fluxes from the $a_{\text {pta }}$ pool associated with these aphid fluxes of $(\mathrm{kg}$ $\left.\mathrm{N} \mathrm{stem}{ }^{-1} \mathrm{~d}^{-1}\right)$ :

$$
\begin{aligned}
O_{\text {Napta } \rightarrow \text { apt } 1} & =I_{\text {apta } \rightarrow \text { apt } 1} M_{\text {Napt1 }}, \quad O_{\text {Napta } \rightarrow \text { ala1 }}=I_{\text {apta } \rightarrow \text { ala } 1} M_{\text {Nala1 } 1} . \\
\text { Total: } & O_{\text {Napta } \rightarrow \text { axx } 1}=O_{\text {Napta } \rightarrow \text { apt1 } 1}+O_{\text {Napta } \rightarrow \text { ala } 1} .
\end{aligned}
$$

The right-side quantities for the first two equations are in Eq (30) and Eq (7).

There are carbon fluxes from apterous adults to respiration, offspring and honeydew [input to the surface litter metabolic pool, Eq (107)]. The carbon intake of the apterous adults is $I_{\text {Cphloem } \rightarrow \text { apta }}\left[\mathrm{Eq}(24), \mathrm{kg} \mathrm{C}\right.$ stem $\left.^{-1} \mathrm{~d}^{-1}\right]$. It is assumed that a fraction, $f_{\text {Caph,resp }}$, of this is respired, giving a respiratory flux from apterous adults of ( $\mathrm{kg} \mathrm{C}$ stem $^{-1} \mathrm{~d}^{-1}$ )

$$
R_{\text {apta }}=f_{\text {Caph,resp }} I_{\text {Cphloem } \rightarrow \text { apta }}, f_{\text {Caph }, \text { resp }}=0.5 .
$$


This value of 0.5 is typical of respiration losses [87].

Some carbon is used for first instar offspring $\left(\mathrm{kg} \mathrm{C} \mathrm{stem}^{-1} \mathrm{~d}^{-1}\right)$ :

$$
O_{\text {Capta } \rightarrow \text { apt } 1}=I_{\text {apta } \rightarrow \text { apt } 1} M_{\text {Capt } 1}, \quad O_{\text {Capta } \rightarrow \text { ala } 1}=I_{\text {apta } \rightarrow \text { ala } 1} M_{\text {Cala } 1},
$$

Total: $O_{\text {Capta } \rightarrow \text { axx1 }}=O_{\text {Capta } \rightarrow \text { apt } 1}+O_{\text {Capta } \rightarrow \text { ala1 } 1}$.

Here we have used Eqs (7) and (30).

The rest is honeydew $\left(\mathrm{kg} \mathrm{C}\right.$ stem ${ }^{-1} \mathrm{~d}^{-1}$ ) [with Eqs (24), (32) and (33)]

$$
O_{\text {Capta } \rightarrow \text { hon }}=I_{\text {Cphloem } \rightarrow \text { apta }}-R_{\text {apta }}-O_{\text {Capta } \rightarrow \text { apt1 }}-O_{\text {Capta } \rightarrow \text { ala1 }} .
$$

This output is input to the surface litter metabolic pool [Eq (107)].

\section{D.4 Development rates of apterous aphids}

These depend principally on temperature $\left(T_{\text {air }}\right)$ and to a lesser extent on nutrition $\left[N_{\text {phloem }}\right.$, Eq (2)]. Aphid density does not seem to be a factor. We assume that day length is not important. For the temperature modifier of aphid development, $f_{\text {Taph,dev }}$, the standard biological temperature response function is assumed as in Eq (17) but with one different parameter, $T_{0}^{\prime}$ (Fig D.4D):

$$
f_{\text {Taph }, \mathrm{dev}}=f\left(T_{\mathrm{air}}, T_{0}^{\prime}=T_{0, \mathrm{aph}, \mathrm{dev}}^{\prime}=30^{\circ} \mathrm{C}\right) .
$$

The Fig D.4D $T_{0}^{\prime}=30$ curve can be compared qualitatively with Duffy et al. ([63], their figure 3; see Section D.4.1 below).

The nutritional effect is small: a $10 \%$ decrease in development rate if $N_{\text {phloem }}$ [Eq (2)] is zero so that $f_{\mathrm{Naph}, \mathrm{dev}, \min }=0.9$. The nutritional modifier of developmental rate, $f_{\mathrm{Naph}, \mathrm{dev}}$, is assumed to be given by a Michaelis-Menten term with:

$$
\begin{aligned}
f_{\text {Naph,dev }} & =f_{\text {Naph,dev,min }}+\left(1-f_{\text {Naph,dev, min }}\right) \frac{N_{\text {phloem }}}{N_{\text {phloem }}+K_{\text {Naph,dev }}}, \\
f_{\text {Naph,dev, min }} & =0.9, \quad K_{\text {Naph,dev }}=1 \mathrm{~kg} \mathrm{~N} \mathrm{~m}^{3} .
\end{aligned}
$$

The $K$ value, giving half-maximal nutritional effect, is equivalent to foliage $\mathrm{N}$ substrate concentration of $N_{\mathrm{le}}=0.01 \mathrm{~kg} \mathrm{~N}$ substrate (kg structural dry matter) ${ }^{-1}$ [Eq (2)]. If $N_{\text {phloem }}=0, f_{\text {Naph,dev }}=0.9$; if $N_{\text {phloem }}=K_{\text {Naph,dev }}, f_{\text {Naph,dev }}=0.95 ; N_{\text {phloem }}$ is large, $f_{\mathrm{Naph}, \mathrm{dev}}=1$. Note that in the Fig $4+0{ }^{\circ} \mathrm{C}$ run, $f_{\mathrm{Naph}, \mathrm{dev}}$ is mostly about $0.97+0.02$ and $N_{\text {phloem }}$ is in the range 2 to 7 [Eq (2)] so the effect of nutrition on developmental rate is small.

The combined effects of temperature [Eq (35), Fig D. $4 \mathrm{D}, T_{0}^{\prime}=30^{\circ} \mathrm{C}$ curve] and $\mathrm{N}$ nutrition on development $[\mathrm{Eq}(36)]$ are

$$
f_{\text {TNaph,dev }}=f_{\text {Taph,dev }} f_{\text {Naph,dev }} .
$$

All the $20{ }^{\circ} \mathrm{C}$ apterous rate constants $\left(\mathrm{d}^{-1}\right)$ are modified by this dimension-free factor:

$$
\begin{aligned}
k_{\mathrm{apt} 1 \rightarrow 2} & =k_{\mathrm{apt} 1 \rightarrow 2,20} f_{\mathrm{TNaph}, \mathrm{dev}}, \quad k_{\mathrm{apt} 2 \rightarrow 3}=k_{\mathrm{apt} 2 \rightarrow 3,20} f_{\mathrm{TNaph}, \mathrm{dev}}, \\
k_{\mathrm{apt} 3 \rightarrow 4} & =k_{\mathrm{apt} 3 \rightarrow 4,20} f_{\mathrm{TNaph}, \mathrm{dev}}, \quad k_{\mathrm{apt} 4 \rightarrow \mathrm{a}}=k_{\mathrm{apt} 4 \rightarrow \mathrm{a}, 20} f_{\mathrm{TNaph}, \mathrm{dev}} . \\
k_{\mathrm{apt} 1 \rightarrow 2,20} & =0.2222^{*}, \quad k_{\mathrm{apt} 2 \rightarrow 3,20}=0.25, \\
k_{\mathrm{apt} 3 \rightarrow 4,20} & =0.2857143, \quad k_{\mathrm{apt} 4 \rightarrow \mathrm{a}, 20}=0.3333^{*} \mathrm{~d}^{-1}, * \text { denotes recurring. }
\end{aligned}
$$

The lifetimes, $\tau(\mathrm{d})$, associated with these $20{ }^{\circ} \mathrm{C}$ rate parameters are

$$
\begin{array}{ll}
\tau_{\text {apt } 1 \rightarrow 2,20}=1 / k_{\text {apt } 1 \rightarrow 2,20}=4.5, & \tau_{\text {apt } 2 \rightarrow 3,20}=1 / k_{\text {apt } 2 \rightarrow 3,30}=4.0 \\
\tau_{\text {apt } 3 \rightarrow 4,20}=1 / k_{\text {apt } 3 \rightarrow 4,20}=3.5, & \tau_{\text {apt } 4 \rightarrow \mathrm{a}, 20}=1 / k_{\text {apt } 4 \rightarrow \mathrm{a}, 30}=3.0 \mathrm{~d} .
\end{array}
$$


Summing, over all $\tau_{\text {apt } 1 \rightarrow \mathrm{a}, 20}=15 \mathrm{~d}$.

The overall value for the transition from 1st apterous instar to apterous adult agrees reasonably with Dixon ([4], p. 109, table 6.1). Our attempts to relate present assumptions to the data, equations and figures of Duffy et al. [63] were unsuccessful. It is assumed that alates develop $15 \%$ more slowly than apterous aphids [Section D.9, Eqs (9) and (80)].

\section{D.4.1 Survival}

As mentioned in the first paragraph of Section D.1.2, survival is a concept used by some authors (e.g. [63]). In this subsection we show how it is related to the present formulation.

Considering the first instar apterous aphids, $a_{\text {apt1 }}$, the rate of transfer (units $\mathrm{d}^{-1}$ ) to the 2nd instar compartment is $k_{\text {apt } 1 \rightarrow 2}$ [Eq (38), Fig 2]. This competes with aphid mortality, $k_{\text {aph,mort }}[\mathrm{Eq}(11)$, Fig D.3A], resulting in a survival probability which is a function of time, survival $(t)$, whose asymptote is survival $(t \rightarrow \infty)$. Both quantities are dimensionless.

$$
\begin{aligned}
& s_{\text {urvival }}(t)=\frac{k_{\text {apt } 1 \rightarrow 2}}{k_{\text {apt } 1 \rightarrow 2}+k_{\text {aph }, \text { mort }}}\left[1-\mathrm{e}^{-\left(k_{\text {apt } 1 \rightarrow 2}+k_{\text {aph }, \text { mort }}\right) t}\right] ; \\
& s_{\text {urvival }}(t \rightarrow \infty)=\frac{k_{\text {apt } 1 \rightarrow 2}}{k_{\text {apt } 1 \rightarrow 2}+k_{\text {aph }, \text { mort }}} .
\end{aligned}
$$

The latter is drawn in Fig D.8B and the quantities determining this in Fig D.8A.

Figure 3 of Duffy et al. [63] compares reasonably with the present formalism and Fig D.8B. The survival fraction is a consequence of two competing rate constants, mortality and development. It may therefore be more pertinent to consider the underlying rate constants shown in Fig D.8A.

Fig D.8. Survival. The temperature dependence of the survival function, Eq (40). A, the terms making up the function are shown: $k_{\mathrm{apt} 1 \rightarrow 2}$ is the specific rate of transfer of aphids from the 1st instar apterous compartment to the second [Fig 2, Eq (38)]; $k_{\text {aph,mort }}$ $[\mathrm{Eq}(11), \mathbf{A}]$ is the specific aphid mortality rate. $\mathbf{B}$, the asymptotic survival function $s_{\text {urvival }}(t \rightarrow \infty)[\mathrm{Eq}(40)]$. The four points shown are from Duffy et al. ([63], their figure $3)$, whose data are from Dean [91]. Go to figure.

\section{D.5 Juvenile apterous (wingless) aphids}

It is convenient to deal with these pools together (Fig 2). The four instars have state variables, $a_{\mathrm{pt} 1, \ldots, 4}$ (aphids per stem). First the pool inputs are defined, then the outputs and last the differential equations.

\section{D.5.1 Inputs: juvenile apterous (wingless) aphids}

These are: $I_{\text {apt } \jmath}, \jmath=1, \ldots, 4$ (aphids stem ${ }^{-1} \mathrm{~d}^{-1}$ ), with (Fig 2)

$$
\begin{aligned}
& I_{\text {apt1 }}=I_{\text {apta } \rightarrow \text { apt } 1}+I_{\text {alaa } \rightarrow \text { apt1 }}, \quad I_{\text {apt2 }}=O_{\text {apt } 1 \rightarrow 2} \\
& I_{\text {apt3 }}=O_{\text {apt } 2 \rightarrow 3}, \quad I_{\text {apt } 4}=O_{\text {apt3 } \rightarrow 4} .
\end{aligned}
$$

The inputs to the first pool are from the reproduction of both apterous and alate adults [Fig 2; Eqs (30) and (74)]. The inputs to the other three pools are equal to the developmental outputs of the preceding pools [Eq (42)], assuming that transfer takes place without loss.

place without 


\section{D.5.2 Outputs: juvenile apterous (wingless) aphids}

The outputs, $O_{\text {apt } \jmath}, \jmath=1, \ldots 4$ (aphids stem ${ }^{-1} \mathrm{~d}^{-1}$ ) from each pool arise from development, mortality, tree thinning and/or foliage pruning. There is no loss of aphid numbers per stem to thinning when whole stems are removed.

Development. Developmental outputs are (aphids stem ${ }^{-1} \mathrm{~d}^{-1}$ )

$$
\begin{aligned}
& O_{\mathrm{apt} 1 \rightarrow 2}=k_{\mathrm{apt} 1 \rightarrow 2} a_{\mathrm{pt} 1}, \quad O_{\mathrm{apt} 2 \rightarrow 3}=k_{\mathrm{apt} 2 \rightarrow 3} a_{\mathrm{pt} 2} \\
& O_{\mathrm{apt} 3 \rightarrow 4}=k_{\mathrm{apt} 3 \rightarrow 4} a_{\mathrm{pt} 3}, O_{\mathrm{apt} 4 \rightarrow \mathrm{a}}=k_{\mathrm{apt} 4 \rightarrow \mathrm{a}} a_{\mathrm{pt} 4} \text {. }
\end{aligned}
$$

The developmental rate constants $\left(\mathrm{d}^{-1}\right)$ are given in Eq (38). The state variables, $a_{\mathrm{pt} \jmath}$, $\jmath=1, \ldots, 4$ (aphids stem ${ }^{-1}$ ) are defined by Eq (47) (Fig 2). The outputs are transferred without loss, providing the inputs (aphids stem ${ }^{-1} \mathrm{~d}^{-1}$ ) of $I_{\text {apt2-4 }}$ in Eq (41) and also the input to apterous adults of

$$
I_{\text {apta }}=I_{\text {apt } 4 \rightarrow \mathrm{a}}=O_{\mathrm{apt} 4 \rightarrow \mathrm{a}} .
$$

Mortality. It is assumed that the same mortality rate constant, $k_{\mathrm{aph}, \mathrm{mort}}$ [Eq (11)], applies to all four instars, leading to outputs of (aphids stem ${ }^{-1} \mathrm{~d}^{-1}$ )

$$
\begin{aligned}
O_{\text {apt } 1 \rightarrow \text { mort }} & =k_{\text {apt }, \text { mort }} a_{\mathrm{pt} 1}, \quad O_{\text {apt } 2 \rightarrow \text { mort }}=k_{\text {apt }, \text { mort }} a_{\mathrm{pt} 2}, \\
O_{\text {apt } 3 \rightarrow \text { mort }} & =k_{\text {apt }, \text { mort }} a_{\mathrm{pt} 3}, \quad O_{\text {apt } 4 \rightarrow \text { mort }}=k_{\text {apt }, \text { mort }} a_{\mathrm{pt} 4}, \\
O_{\text {apti }} & =O_{\text {apt } 1 \rightarrow \text { mort }}+O_{\text {apt } 2 \rightarrow \text { mort }}+O_{\text {apt } 3 \rightarrow \text { mort }}+O_{\text {apt } 4 \rightarrow \text { mort }}, \\
O_{\text {apt } \rightarrow \text { mort }} & =O_{\text {apti } \rightarrow \text { mort }}+O_{\text {apta } \rightarrow \text { mort }} .
\end{aligned}
$$

In the last two lines we calculate total instar mortality, $O_{\text {apti } \rightarrow \text { mort }}$ and total apterous aphid mortality, $O_{\text {apt } \rightarrow \text { mort }}$.

Pruning. Pruning is assumed to remove aphids from the aphid number per stem pools, as in Eq (14). The output fluxes are (aphids stem ${ }^{-1} \mathrm{~d}^{-1}$ )

$$
\begin{aligned}
O_{\text {apt } 1 \rightarrow \text { prune }} & =k_{\text {apt }, \text { prune }} a_{\mathrm{pt} 1}, \quad O_{\text {apt } 2 \rightarrow \text { prune }}=k_{\text {apt }, \text { prune }} a_{\mathrm{pt} 2}, \\
O_{\text {apt } 3 \rightarrow \text { prune }} & =k_{\text {apt }, \text { prune }} a_{\text {pt } 3}, \quad O_{\text {apt } 4 \rightarrow \text { prune }}=k_{\text {apt }, \text { prune }} a_{p t 4}, \\
O_{\text {apti }} & =O_{\text {apt } 1 \rightarrow \text { prune }}+O_{\text {apt } 2 \rightarrow \text { prune }}+O_{\text {apt } 3 \rightarrow \text { prune }}+O_{\text {apt } 4 \rightarrow \text { prune }}, \\
O_{\text {apt } \rightarrow \text { prune }} & =O_{\text {apti } \rightarrow \text { prune }}+O_{\text {apta } \rightarrow \text { prune }} .
\end{aligned}
$$

The state variables, $a_{\mathrm{pt} \jmath}, \jmath=1, \ldots, 4$ (aphids $\mathrm{stem}^{-1}$ ) are defined by Eq (47) (Fig 2). The last two of $\mathrm{Eq}(45)$ give the total apterous instar output to pruning and with the first of Eq (14), total outputs of apterous instars and total apterous aphids to pruning. See Section D.1.2 'mortality'. The pruning rate constant $k_{\mathrm{le} \rightarrow \text { prune }}=0 \mathrm{~d}^{-1}$ in these aphid studies [Eq (14)].

Combining Eqs (42), (44) and (45), the total outputs from the four pools are (aphids stem $\left.^{-1} \mathrm{~d}^{-1}\right)$ :

$$
\begin{aligned}
& O_{\text {apt } 1}=O_{\text {apt } 1 \rightarrow 2}+O_{\text {apt } 1 \rightarrow \text { mort }}+O_{\text {apt } 1 \rightarrow \text { prune }} \\
& O_{\text {apt } 2}=O_{\text {apt } 2 \rightarrow 3}+O_{\text {apt } 2 \rightarrow \text { mort }}+O_{\text {apt } 2 \rightarrow \text { prune }} \\
& O_{\text {apt } 3}=O_{\text {apt } 3 \rightarrow 4}+O_{\text {apt } 3 \rightarrow \text { mort }}+O_{\text {apt } 3 \rightarrow \text { prune }} \\
& O_{\text {apt } 4}=O_{\text {apt } 4 \rightarrow \mathrm{a}}+O_{\text {apt } 4 \rightarrow \text { mort }}+O_{\text {apt } 4 \rightarrow \text { prune }}
\end{aligned}
$$




\section{D.5.3 Differential equations: juvenile apterous (wingless) aphids}

With Eqs (41) and (46), the differential equations (aphids stem ${ }^{-1} \mathrm{~d}^{-1}$ ) and initial values for the four apterous instar state variables are (aphids stem ${ }^{-1}$ ):

$$
\frac{\mathrm{d} a_{\mathrm{pt} \jmath}}{\mathrm{d} t}=I_{\mathrm{apt} \jmath}-O_{\mathrm{apt} \jmath}, \text { for } \jmath=1, \ldots 4 .
$$

At $t=0 \mathrm{~d}: a_{\mathrm{pt}_{\jmath}}=0$ for $\jmath=1, \ldots, 4$ aphids stem $^{-1}$.

\section{D.5.4 Nitrogen and carbon fluxes for the four apterous instar pools}

It is assumed that the $\mathrm{N}$ taken up from the phloem is the amount required to increase the $\mathrm{N}$ component of mass of the aphids which enter the next pool. Therefore, using an obvious notation $\left(\mathrm{kg} \mathrm{N}\right.$ stem $\left.{ }^{-1} \mathrm{~d}^{-1}\right)$ :

$$
\begin{aligned}
& I_{\text {Nphloem } \rightarrow \text { apt } 1}=O_{\text {apt } 1 \rightarrow 2}\left(M_{\text {Napt } 2}-M_{\text {apt } 1}\right), \\
& I_{\text {Nphloem } \rightarrow \text { apt } 2}=O_{\text {apt } 2 \rightarrow 3}\left(M_{\text {Napt } 3}-M_{\text {apt } 2}\right), \\
& I_{\text {Nphloem } \rightarrow \text { apt } 3}=O_{\text {apt } 3 \rightarrow 4}\left(M_{\text {Napt } 4}-M_{\text {apt3 }}\right), \\
& I_{\text {Nphloem } \rightarrow \text { apt } 4}=O_{\text {apt } 4 \rightarrow 2}\left(M_{\text {Napta }}-M_{\text {apt } 4}\right) .
\end{aligned}
$$

Aphid N contents are given in Eq (7); developmental outputs in Eq (42). Total N intake from the phloem by the four apterous instars (apti) is $\left(\mathrm{kg} \mathrm{N} \mathrm{stem}^{-1} \mathrm{~d}^{-1}\right)$ :

$$
I_{\text {Nphloem } \rightarrow \text { apti }}=I_{\text {Nphloem } \rightarrow \text { apt1 }}+I_{\text {Nphloem } \rightarrow \text { apt2 }}+I_{\text {Nphloem } \rightarrow \text { apt } 3}+I_{\text {Nphloem } \rightarrow \text { apt } 4}
$$

The $\mathrm{C}$ flux accompanying this $\mathrm{N}$ flux is $\left(\mathrm{kg} \mathrm{C} \mathrm{stem}{ }^{-1} \mathrm{~d}^{-1}\right)$ :

$$
I_{\text {Cphloem } \rightarrow \text { apti }}=r_{\mathrm{CNphloem}} I_{\mathrm{Nphloem} \rightarrow \text { apti }} .
$$

The phloem C:N ratio is given in $\mathrm{Eq}(3)$.

The $\mathrm{C}$ taken from the phloem is used for respiration, increase in instar mass and honeydew. The earlier treatment is followed [Eqs (32)-(34)].

The amount respired is $\left(\mathrm{kg} \mathrm{C}\right.$ stem $\left.{ }^{-1} \mathrm{~d}^{-1}\right)$

$$
R_{\text {apti }}=f_{\text {Caph,resp }} I_{\text {Cphloem } \rightarrow \text { apti }},
$$

where fraction, $f_{\text {Caph,resp }}$, is defined by Eq (32).

The increase in instar mass from aphid development (dev) also requires $\mathrm{C}$ from the phloem. The four input $(I)$ components of this and the total phloem $\mathrm{C}$ output to supply these four inputs are $\left(\mathrm{kg} \mathrm{C}\right.$ stem $\left.{ }^{-1} \mathrm{~d}^{-1}\right)$

$$
\begin{aligned}
I_{\text {Cphloem } \rightarrow \text { apt } 1} & =O_{\text {apt } 1 \rightarrow 2}\left(M_{\text {Capt } 2}-M_{\text {Capt } 1}\right) \\
I_{\text {Cphloem } \rightarrow \text { apt } 2} & =O_{\text {apt } 2 \rightarrow 3}\left(M_{\text {Capt } 3}-M_{\text {Capt } 2}\right) \\
I_{\text {Cphloem } \rightarrow \text { apt } 3} & =O_{\text {apt3 } \rightarrow 4}\left(M_{\text {Capt } 4}-M_{\text {Capt } 3}\right) \\
I_{\text {Cphloem } \rightarrow \text { apt } 4} & =O_{\text {apt } 4 \rightarrow \mathrm{a}}\left(M_{\text {Capta }}-M_{\text {Capt } 4}\right) \\
O_{\text {Cphloem } \rightarrow \text { apti }} & =I_{\text {Cphloem } \rightarrow \text { apt } 1}+I_{\text {Cphloem } \rightarrow \text { apt } 2}+I_{\text {Cphloem } \rightarrow \text { apt } 3}+I_{\text {Cphloem } \rightarrow \text { apt } 4}
\end{aligned}
$$

Equations (42) and (7) are used in the above.

Excess $\mathrm{C}$ is excreted as honeydew (hon), which is input to the surface litter metabolic pool [Eq (107)] ([34], chapter 5; $\mathrm{kg} \mathrm{C}$ stem $^{-1} \mathrm{~d}^{-1}$ ):

$$
O_{\text {Capti } \rightarrow \text { hon }}=I_{\text {Cphloem } \rightarrow \text { apti }}-R_{\text {apti }}-O_{\text {Cphloem } \rightarrow \text { apti }} \text {. }
$$


Eqs (50), (51) and (52) are used here.

Mortality (mort) gives rise to $\mathrm{C}$ and $\mathrm{N}$ outputs of $\left(\mathrm{kg} \mathrm{C}, \mathrm{N}\right.$ stem $\left.{ }^{-1} \mathrm{~d}^{-1}\right)$ :

$$
\begin{aligned}
& O_{\text {Capti } \rightarrow \text { mort }}=O_{\text {apt1 } \rightarrow \text { mort }} M_{\text {Capt } 1}+O_{\text {apt } 2 \rightarrow \text { mort }} M_{\text {Capt2 }} \\
& +O_{\text {apt } 3 \rightarrow \text { mort }} M_{\text {Capt3 }}+O_{\text {apt } 4 \rightarrow \text { mort }} M_{\text {Capt } 4}, \\
& O_{\text {Napti } \rightarrow \text { mort }}=O_{\text {apt } 1 \rightarrow \text { mort }} M_{\text {Napt } 1}+O_{\text {apt } 2 \rightarrow \text { mort }} M_{\text {Napt } 2} \\
& +O_{\text {apt3 } \rightarrow \text { mort }} M_{\mathrm{Napt} 3}+O_{\text {apt } 4 \rightarrow \operatorname{mort}} M_{\mathrm{Napt} 4} .
\end{aligned}
$$

Equations (44) and (7) have been applied. These fluxes are input to the soil surface litter pools [Eqs (108) and (118)].

Pruning similarly gives rise to $\mathrm{C}$ and $\mathrm{N}$ outputs of $\left(\mathrm{kg} \mathrm{C}, \mathrm{N}\right.$ stem $\left.{ }^{-1} \mathrm{~d}^{-1}\right)$ :

$$
\begin{aligned}
& O_{\text {Capti } \rightarrow \text { prune }}=O_{\text {apt } 1 \rightarrow \text { prune }} M_{\text {Capt1 }}+O_{\text {apt2 } \rightarrow \text { prune }} M_{\text {Capt2 }} \\
& +O_{\text {apt } 3 \rightarrow \text { prune }} M_{\text {Capt } 3}+O_{\text {apt } 4 \rightarrow \text { prune }} M_{\text {Capt } 4}, \\
& O_{\text {Napti } \rightarrow \text { prune }}=O_{\text {apt1 } \rightarrow \text { prune }} M_{\text {Napt1 }}+O_{\text {apt2 } \rightarrow \text { prune }} M_{\text {Napt2 }} \\
& +O_{\text {apt } 3 \rightarrow \text { prune }} M_{\text {Napt3 }}+O_{\text {apt } 4 \rightarrow \text { prune }} M_{\text {Napt } 4} \text {. }
\end{aligned}
$$

Equations (45) and (7) have been used, but see Eq (14).

\section{D.6 Alate (winged) adult aphids, $a_{\text {laa }}$}

\section{D.6.1 Inputs: alate (winged) adult aphids}

In this case [cf. Eq (8) and above], there are potentially two inputs. The first is from development of the 4 th alate instar, $a_{\mathrm{la} 4}$; this input, $I_{\text {ala4 } \rightarrow \text { alaa }}$, is calculated in Eq (83). The second is from immigration, currently equated to zero [but see Eq (64) where $a_{\text {laa }}$ is set to a non-zero value]:

$$
I_{\text {imm } \rightarrow \text { alaa }}=0 \text { aphids stem }{ }^{-1} \mathrm{~d}^{-1} \text {. }
$$

The total input to the alate adult pool is (aphids stem ${ }^{-1} \mathrm{~d}^{-1}$ )

$$
I_{\text {alaa }}=I_{\text {ala } 4 \rightarrow \text { alaa }}+I_{\text {imm,alaa }} \text {. }
$$

This requires $\mathrm{C}$ and $\mathrm{N}$ fluxes $\left(\mathrm{kg} \mathrm{C}, \mathrm{N}\right.$ stem ${ }^{-1} \mathrm{~d}^{-1}$ ) of $[c f$. Eq (8)]:

$$
I_{\text {Cala } \rightarrow \mathrm{a}}=I_{\text {alaa }} M_{\text {Cala }}, I_{\text {Nala } \rightarrow \mathrm{a}}=I_{\text {alaa }} M_{\text {Nala }} .
$$

We have used Eq (7).

\section{D.6.2 Outputs: alate (winged) adult aphids}

There is assumed to be no aphid loss accompanying the foliage litter flux. Thinning does not affect aphid numbers per stem. There are outputs to mortality, pruning and emigration.

Mortality. The aphid flux to mortality, $O_{\text {alaa } \rightarrow \text { mort }}$ (aphid number $\operatorname{stem}^{-1} \mathrm{~d}^{-1}$ ), is assumed to depend on temperature and nutrition. The specific rate constant, $k_{\mathrm{aph} \text {,mort }}$ $\left(\mathrm{d}^{-1}\right)$ assumed to be the same for all aphid morphs, is calculated in Eq (11). The output from the adult alate pool to mortality and the accompanying $\mathrm{C}$ and $\mathrm{N}$ fluxes are $[c f$. Eqs (12) and (13)]

$$
\begin{aligned}
O_{\text {alaa } \rightarrow \text { mort }} & =k_{\text {aph }, \text { mort }} a_{\text {alaa }}, \\
O_{\text {Cala } \rightarrow \text { mort }} & =O_{\text {alaa } \rightarrow \text { mort }} M_{\text {Cala }}, \quad O_{\text {Nala } \rightarrow \text { mort }}=O_{\text {alaa } \rightarrow \text { mort }} M_{\text {Nala }} .
\end{aligned}
$$

Aphid $\mathrm{C}$ and $\mathrm{N}$ contents are in Eq (7). Units are aphids stem ${ }^{-1} \mathrm{~d}^{-1}$ and $\mathrm{kg} \mathrm{C}, \mathrm{N}$ stem ${ }^{-1}$ $\mathrm{d}^{-1}$. These fluxes are input to the soil surface litter pools [Eqs (108) and (118)]. 
Pruning. The pruning flux, $O_{\text {alaa } \rightarrow \text { prune }}$ (aphids stem ${ }^{-1} \mathrm{~d}^{-1}$ ) and the associated fluxes of $\mathrm{C}$ and N, are, after Eq (14) and with Eqs (7) and (14):

$$
\begin{aligned}
O_{\text {alaa } \rightarrow \text { prune }} & =k_{\text {le, prune }} a_{\text {alaa }}, \\
O_{\text {Cala } \rightarrow \text { prune }} & =O_{\text {alaa } \rightarrow \text { prune }} M_{\text {Cala }}, \quad O_{\text {Nala } \rightarrow \text { prune }}=O_{\text {alaa } \rightarrow \text { prune }} M_{\text {Nala }} .
\end{aligned}
$$

Units of the last two equations are kg aphid $\mathrm{C}, \mathrm{N}$ stem ${ }^{-1} \mathrm{~d}^{-1}$.

Emigration. This flux, $O_{\text {alaa } \rightarrow \text { emi }}$ (aphid number stem ${ }^{-1} \mathrm{~d}^{-1}$ ) [Eq (61)], is equal to a standard temperature $\left(20^{\circ} \mathrm{C}\right)$ rate constant, $k_{\text {alaa } \rightarrow \text { emi20 }}$, multiplied by a temperature-dependent function $f\left(T_{\text {air }}\right)$ for which the default parameter values are applied [Eq (17), Fig D.4]. Also, at low aphid densities $\left[\rho_{\text {aph }}, \mathrm{Eq}(5)\right]$ so that the incoming alates do not immediately depart, emigration is switched off by multiplying by $f_{\text {palaa } \rightarrow \text { ala1 }}\left[\mathrm{Eq}(71), c f . \mathrm{Eq}(26)\right.$, Fig D.7B]. The combined rate parameter is (units: $\mathrm{d}^{-1}$ )

$$
k_{\text {alaa } \rightarrow \text { emi }}=k_{\text {alaa } \rightarrow \text { emi20 }} f\left(T_{\text {air }}\right) f_{\text {palaa } \rightarrow \text { ala } 1} ; \quad k_{\text {alaa } \rightarrow \mathrm{emi} 20}=1 \mathrm{~d}^{-1} .
$$

When the aphids are crowded, aphid density $\rho_{\text {aph }}$ is large, $f_{\text {palaa } \rightarrow \text { ala1 }} \rightarrow 1$ [Eq (71)] and emigration of adult alates occurs almost immediately. With the initial $t=0$ values of $a_{\mathrm{ph}}=a_{\text {laa }}=10$ aphids per stem [Eqs Eq (64) and Eq (4)] and $A_{\text {leaf,aph }}=0.009[\mathrm{Eq}(5)]$, $\rho_{\text {aph }}=1111.1[\mathrm{Eq}(5)]$ and $f_{\text {palaa } \rightarrow \text { ala } 1}=0.552$. Also at $t=0, T_{\text {air }}=1.8^{\circ} \mathrm{C}($ Fig $3 \mathrm{~A})$, so that $f\left(T_{\text {air }}\right)=0.019$. Therefore [with Eq $(7)$ ]

$$
\begin{aligned}
O_{\text {alaa } \rightarrow \text { emi }} & =k_{\text {alaa } \rightarrow \text { emi }} a_{\text {alaa }}, \\
\text { at } t & =0, O_{\text {alaa } \rightarrow \text { emi }}=0.103 \text { aphids } \text { stem }^{-1} \mathrm{~d}^{-1} \\
O_{\text {Calaa } \rightarrow \text { emi }} & =O_{\text {alaa } \rightarrow \text { emi }} M_{\text {Cala }}, \quad O_{\text {Nala } \rightarrow \text { emi }} M_{\text {Nala }} . \\
O_{\text {alaa } \rightarrow \text { emi,ya }} & =\int_{t-365}^{t} O_{\text {alaa } \rightarrow \text { emi }} \mathrm{dt} .
\end{aligned}
$$

Alate adults $\left(a_{\text {laa }}\right.$, Fig 2$)$ are the only morph that is able to emigrate. Units are aphids stem $^{-1} \mathrm{~d}^{-1}$ and $\mathrm{kg} \mathrm{C}, \mathrm{N}$ stem ${ }^{-1} \mathrm{~d}^{-1}$. Equation (62d) gives the yearly accumulation (ya) of emigrants (aphids stem ${ }^{-1} \mathrm{~d}^{-1}$ ). For the simulation shown in Fig $4,+0{ }^{\circ} \mathrm{C}$ which is chaotic, this also behaves chaotically. The total output of adult alate aphids (aphids stem ${ }^{-1} \mathrm{~d}^{-1}$ ) is obtained by adding the contributions [Eqs (55), (60) and (62); cf. Eq (15)]:

$$
O_{\text {alaa }}=O_{\text {alaa } \rightarrow \text { mort }}+O_{\text {alaa } \rightarrow \text { prune }}+O_{\text {alaa } \rightarrow \text { emi }} .
$$

$O_{\text {alaa }}$ is used in Eq (99) to calculate fractional outputs.

\section{D.6.3 Differential equation: alate (winged) adult aphids}

The differential equation (adult alates stem ${ }^{-1} \mathrm{~d}^{-1}$ ) and initial value for the state variable, $a_{\text {laa }}$, are [with Eqs (57) and (63)]

$$
\frac{\mathrm{d} a_{\text {laa }}}{\mathrm{d} t}=I_{\text {alaa }}-O_{\text {alaa }}, \quad a_{\text {laa }}(t=0)=10 \text { alate adults } \text { stem }^{-1} .
$$

It is assumed that ten alate (winged) adult aphids fly in and colonize the stem at a specified time (usually $t=0 \mathrm{~d}$ ). 


\section{D.7 Alate aphid fecundity}

The effect of temperature on alate fecundity is assumed to be the same as in Eq (18) for apterous aphid fecundity. The effect of nutrition on fecundity, manifest here through the $\mathrm{N}$ concentration in the phloem, $N_{\text {phloem }}[\mathrm{Eq}(2)]$, can be made specific - i.e. different for alate and apterous aphids, although here we assume apterous and alate adult aphids are equally fecund. The relevant equations are summarized below [cf. Eqs (19) to (24) for details]; results are given in Fig D.5.

824 825 826 827 828 829 830

Fig D.9. Fractional output fluxes. Fractional output fluxes of alate adults to mortality, $f_{\text {Oalaa } \rightarrow \text { mort }}$ (solid line) and to emigration, $f_{\text {Oalaa } \rightarrow \text { emi }}[\mathrm{Eq}(99)]$ (dash-dot line) over three years post-infection [Eq (64)] at time $t=0$ for a plantation in a northern Britain environment (Section 4.1). The state variable for alate adults $a_{\text {alaa }}$ (Fig 2) is shown by the dashed-dot-dot-dot line [Eq (64)] with reference to the right side ordinate; initial value is 10 and is therefore not shown. Go to figure.

The maximum volume intake rate of an alate adult, $v_{\text {alaa,max }}\left(\mathrm{m}^{3}\right.$ aphid $\left.^{-1} \mathrm{~d}^{-1}\right)$, places a limit on the maximum $\mathrm{N}$ intake from the phloem, giving a maximum phloem-volume-limited N intake [combining and modifying Eqs (19) and (20), but keeping the same parameter values]:

$$
\begin{aligned}
v_{\text {alaa,max }} & =f_{\text {Taph,fec }} v_{\text {alaa,max } 20}, \\
v_{\text {alaa,max20 }} & =0.2 \times 10^{-6} \mathrm{~m}^{3} \text { aphid }^{-1} \mathrm{~d}^{-1}, \text { where } \\
I_{\text {Nphloem,valaa,max }} & =v_{\text {alaa,max }} N_{\text {phloem }} .
\end{aligned}
$$

See Eq (18) for $f_{\text {Taph,fec }}$. Units of the last equation are $\mathrm{kg} N$ aphid ${ }^{-1} \mathrm{~d}^{-1}$.

The maximum amount of $\mathrm{N}$ which can be processed $(p)$ is $[c f . \operatorname{Eq}(21)]$

$$
\begin{aligned}
I_{\text {Npalaa,max }} & =f_{\text {Taph,fec }} I_{\text {Npalaa,max } 20}, \\
I_{\text {Npalaa,max20 }} & =2 \times 10^{-6} \mathrm{~kg} \mathrm{~N} \text { aphid }^{-1} \mathrm{~d}^{-1} .
\end{aligned}
$$

The $\mathrm{N}$ ingested per adult alate is the least of the volume-intake-limited [Eq (65)] or the processing-limited $[\mathrm{Eq}(66)]$ values $\left(\mathrm{kg} \mathrm{N}\right.$ aphid $\left.{ }^{-1} \mathrm{~d}^{-1}\right)$ :

$$
I_{\text {Nphloem } \rightarrow \text { alaa, aphid }}=\min \left\{I_{\text {Nphloem,valaa,aphid }}, I_{\text {Npalaa,max }}\right\} .
$$

Dividing by $N_{\text {phloem }}[\mathrm{Eq}(2)]$, the actual volume of phloem sap ingested per alate adult aphid is $\left(\mathrm{m}^{3}\right.$ phloem sap aphid $\left.{ }^{-1}\right)[c f$. Eq (23)]

$$
v_{\text {phloem } \rightarrow \text { alaa }}=\frac{I_{\text {Nphloem } \rightarrow \text { alaa }, \text { aphid }}}{N_{\text {phloem }}} .
$$

The $\mathrm{C}$ intake per aphid $\left(\mathrm{kg} \mathrm{C}\right.$ aphid $\left.{ }^{-1} \mathrm{~d}^{-1}\right)$ and then the $\mathrm{N}$ and $\mathrm{C}$ intakes per stem $(\mathrm{kg}$ $\mathrm{N}, \mathrm{C}$ stem $^{-1} \mathrm{~d}^{-1}$ ) are [cf. Eq (24)]:

$$
\begin{aligned}
I_{\text {Cphloem } \rightarrow \text { alaa, aphid }} & =v_{\text {phloem } \rightarrow \text { alaa }} C_{\text {phloem }}, \\
I_{\text {Nphloem } \rightarrow \text { alaa }} & =a_{\text {laa }} I_{\text {Nphloem } \rightarrow \text { alaa,aphid }}, \\
I_{\text {Cphloem } \rightarrow \text { alaa }} & =a_{\text {laa }} I_{\text {Cphloem } \rightarrow \text { alaa, aphid }} .
\end{aligned}
$$

Here Eqs (68), (2), (64) and (67) are employed. 


\section{D.8 Alate:apterous ratio in offspring from alate adults}

The treatment above for the alate:apterous ratio in the offspring of apterous adults is followed exactly (Section D.3), but with the possibility of different parameters for the alates. Eqs (25)-(28) become

$$
\begin{aligned}
& f_{\text {Talaa } \rightarrow \text { ala } 1}=\frac{\left(T_{\text {air }}\right)^{q_{\text {Tala }}}}{\left(T_{\text {air }}\right)^{q_{\text {Tala }}}+\left(K_{\text {Tala }}\right)^{q_{\text {Tala }}}}, \quad q_{\text {Tala }}=2, \quad K_{\text {Tala }}=10^{\circ} \mathrm{C} .
\end{aligned}
$$

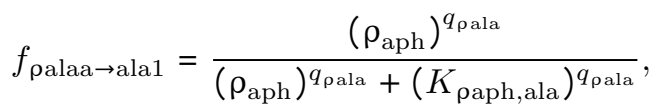

$$
\begin{aligned}
& q_{\text {pala }}=2, \quad K_{\text {paph,ala }}=1000 \text { aphids }\left(\mathrm{m}^{2} \text { leaf area }\right)^{-1} \text {. } \\
& f_{\text {Nala } \rightarrow \text { ala } 1}=\frac{\left(K_{\text {Nala }}\right)^{q_{\text {Nala }}}}{\left(K_{\text {Nala }}\right)^{q_{\text {Nala }}}+\left(N_{\text {phloem }}\right)^{q_{\text {Nala }}}}, \\
& q_{\text {Nala }}=2, \quad K_{\text {Nala }}=4 \mathrm{~kg} \mathrm{~N} \mathrm{~m}^{-3} \text {. } \\
& f_{\text {alaa } \rightarrow \text { ala1 }}=f_{\text {Tala } \rightarrow \text { ala1 } 1} f_{\text {palaa } \rightarrow \text { ala1 } 1} f_{\text {Nala } \rightarrow \text { ala1 } 1} . \\
& f_{\text {alaa } \rightarrow \text { ala } 1}=1-f_{\text {alaa } \rightarrow \text { ala } 1} \text {. }
\end{aligned}
$$

These quantities are drawn in Fig D.5 for the alate fractions of the progeny of apterous adults, where the parameterization is assumed the same as for alate adults.

\section{D.8.1 Total fecundity and fractional fecundity of alate adults}

Now that we have calculated the fractions of offspring from alate adults which are alate and which are apterous, $f_{\text {alaa } \rightarrow \text { ala1 } 1}$ and $f_{\text {alaa } \rightarrow \text { apt } 1}$ in Eq (73), we are able to calculate the total fecundity of alate adults, Oalaa $\rightarrow$ axx1 $\left(1\right.$ st instar aphids stem $\left.{ }^{-1} \mathrm{~d}^{-1}\right)[c f$. Section D.3.4, Eq (29) for apterous adults].

The $\mathrm{N}$ ingested by alate adults $\left[I_{\mathrm{Nphloem} \rightarrow \text { alaa }},\left(\mathrm{kg} \mathrm{N}_{\mathrm{N} \text { stem }}{ }^{-1} \mathrm{~d}^{-1}\right), \mathrm{Eq}(69)\right]$ is converted into alate and apterous first-instar nymphs, giving a total output of first-instar nymphs $[c f . \mathrm{Eq}(29)]$ and outputs and inputs to these pools with [cf. Eq (30)]

$$
\begin{aligned}
O_{\text {alaa } \rightarrow \text { axx } 1} & =O_{\text {alaa } \rightarrow \text { ala } 1}+O_{\text {alaa } \rightarrow \text { apt } 1} \\
& =\frac{I_{\text {Nphloem } \rightarrow \text { alaa }}}{f_{\text {alaa } \rightarrow \text { apt } 1} M_{\text {Napt1 }}+f_{\text {alaa } \rightarrow \text { ala } 1} M_{\text {Nala1 } 1}}, \\
O_{\text {alaa } \rightarrow \text { apt1 } 1} & =f_{\text {alaa } \rightarrow \text { apt1 } 1} O_{\text {alaa } \rightarrow \text { axx } 1}, \quad O_{\text {alaa } \rightarrow \text { ala } 1}=f_{\text {alaa } \rightarrow \text { ala } 1} O_{\text {alaa } \rightarrow \text { axx } 1}, \\
I_{\text {alaa } \rightarrow \text { apt1 }} & =O_{\text {alaa } \rightarrow \text { apt1 } 1}, \quad I_{\text {alaa } \rightarrow \text { ala } 1}=O_{\text {alaa } \rightarrow \text { ala1 } 1} . \\
f_{\text {fecalaa }} & =\frac{O_{\text {alaa } \rightarrow \text { axx } 1}}{a_{\text {laa }}} .
\end{aligned}
$$

Here the total 1st instar progeny output from alate adults is $O_{\text {alaa } \rightarrow \text { axx } 1}\left(\right.$ aphids stem $^{-1}{ }_{861}$ $\left.\mathrm{d}^{-1}\right)$ and the total fractional fecundity of alate adults is $f_{\text {fecalaa }}\left(\mathrm{d}^{-1}\right)$.

\section{D.8.2 Associated $\mathrm{N}$ and $\mathrm{C}$ fluxes}

The $\mathrm{N}$ fluxes associated with these fluxes of aphids are $\left(\mathrm{kg} \mathrm{N} \mathrm{stem}{ }^{-1} \mathrm{~d}^{-1}\right)$

$$
\text { with a total of } O_{\text {Nalaa } \rightarrow \text { axx } 1}=O_{\text {Nalaa } \rightarrow \text { apt1 }}+O_{\text {Nalaa } \rightarrow \text { ala } 1} \text {. }
$$


The carbon intake of the alate adults is $I_{\mathrm{Cphloem} \rightarrow \text { alaa }}\left[\mathrm{Eq}(69),\left(\mathrm{kg} \mathrm{C} \mathrm{stem}^{-1} \mathrm{~d}^{-1}\right)\right]$. There are carbon fluxes $\left(\mathrm{kg} \mathrm{C}\right.$ stem $\left.{ }^{-1} \mathrm{~d}^{-1}\right)$ to respiration, offspring and the residual $\mathrm{C}$ flux goes to honeydew [cf. Eqs (32) to (34)]:

$$
\begin{aligned}
R_{\text {alaa }} & =f_{\text {Caph,resp }} I_{\text {Cphloem } \rightarrow \text { alaa }} . \\
O_{\text {Calaa } \rightarrow \text { ala1 }} & =I_{\text {alaa } \rightarrow \text { ala1 }} M_{\text {Cala1 } 1}, O_{\text {Calaa } \rightarrow \text { apt1 }}=I_{\text {alaa } \rightarrow \text { apt1 }} M_{\text {Capt1 } 1} . \\
O_{\text {Calaa } \rightarrow \text { hon }} & =I_{\text {Cphloem } \rightarrow \text { alaa }}-R_{\text {alaa }}-O_{\text {Calaa } \rightarrow \text { ala1 } 1}-O_{\text {Calaa } \rightarrow \text { apt1 }} .
\end{aligned}
$$

Here on the right side of Eqs (76) to (78) we have used Eqs (32), (69), (74) and (7). The honeydew output is input to the surface litter metabolic pool [see Eq (107) and above].

\section{D.9 Development rates of alate aphids}

These are treated as in Eqs (35) to (37) (Section D.4) for apterous aphids, although development rates are slightly different for alate instars. We replace Eq (38) by

$$
\begin{aligned}
k_{\text {ala } \rightarrow 2} & =k_{\text {ala } \rightarrow 2,20} f_{\mathrm{TNaph}, \mathrm{dev}}, \quad k_{\mathrm{ala} 2 \rightarrow 3}=k_{\text {ala } 2 \rightarrow 3,20} f_{\mathrm{TNaph}, \mathrm{dev}}, \\
k_{\mathrm{ala} 3 \rightarrow 4} & =k_{\text {ala3 } \rightarrow 4,20} f_{\mathrm{TNaph}, \mathrm{dev}}, \quad k_{\text {ala } 4 \rightarrow \mathrm{a}}=k_{\text {ala } 4 \rightarrow \mathrm{a}, 20} f_{\mathrm{TNaph}, \mathrm{dev}} . \\
k_{\text {ala1 } \rightarrow 2,20} & =0.1888^{*}, \quad k_{\text {ala } 2 \rightarrow 3,20}=0.2125, \\
k_{\text {ala3 } \rightarrow 4,20} & =0.24285699, \quad k_{\text {ala } 4 \rightarrow \mathrm{a}, 20}=0.283333^{*} \mathrm{~d}^{-1}, * \text { denotes recurring. }
\end{aligned}
$$

Here $f_{\text {TNaph,dev }}$ is given by Eq (37). The lifetimes associated with these $20{ }^{\circ} \mathrm{C}$ rate constants are

$$
\begin{gathered}
\tau_{\text {ala } \rightarrow 2,20}=1 / k_{\text {ala } \rightarrow 2,20}=5.294, \quad \tau_{\text {ala } 2 \rightarrow 3,20}=1 / k_{\text {ala } 2 \rightarrow 3,20}=4.706 \\
\tau_{\text {ala } 3 \rightarrow 4,20}=1 / k_{\text {ala3 } \rightarrow 4,20}=4.118, \\
\text { Summing, overall } \tau_{\text {ala } 1 \rightarrow \mathrm{a}, 20}=17.6 \mathrm{~d} .
\end{gathered}
$$

The overall value agrees reasonably with Dixon ([4], p. 109, their table 6.1). Alates develop 15\% more slowly than apterous aphids [loc. cit., Dixon refers to Fisher [93] for data on the green spruce aphid]. See also Section D.4.1 on survival.

\section{D.10 Juvenile alate (winged) aphids}

There are four instars, with state variables $a_{\mathrm{la} 1, \ldots, 4}$ (aphids per stem) (Fig 2). The treatment is the same as above for the apterous instars (Section D.5) where the pools are treated together, defining first the inputs, then the outputs and last the differential equations. The equations are summarized below.

\section{D.10.1 Inputs: juvenile alate (winged) aphids}

Inputs, $I_{\text {ala }}, \jmath=1, \ldots, 4$ (aphids stem ${ }^{-1} \mathrm{~d}^{-1}$ ), to these pools are [Fig 2, cf. Eq (41)]

$$
\begin{aligned}
& I_{\text {ala } 1}=I_{\text {apta } \rightarrow \text { ala } 1}+I_{\text {alaa } \rightarrow \text { ala } 1}, \quad I_{\text {ala } 2}=O_{\text {ala } 1 \rightarrow 2} \\
& I_{\text {ala3 }}=O_{\text {ala2 } \rightarrow 3}, \quad I_{\text {ala } 4}=O_{\text {ala } 3 \rightarrow 4} .
\end{aligned}
$$

The inputs to the first pool are from the reproduction of both apterous and alate adults [Fig 2, Eqs (30) and (74). The inputs to the other three pools are equal to the developmental outputs of the preceding pool [Eq (82)]. It is assumed that transfer takes place without loss. 


\section{D.10.2 Outputs: juvenile alate (winged) aphids}

The outputs, $O_{\text {ala } \jmath}, \jmath=1, \ldots, 4$, arise from development, mortality and tree/foliage pruning. There is no loss of aphid numbers per stem to thinning when whole stems are removed.

Development. The developmental output fluxes from the four alate instars are $[c f$. Eq (42)] (aphids stem $\left.{ }^{-1} \mathrm{~d}^{-1}\right)$ :

$$
\begin{array}{ll}
O_{\text {ala } 1 \rightarrow 2}=k_{\text {ala } 1 \rightarrow 2} a_{\mathrm{la} 1}, & O_{\text {ala } 2 \rightarrow 3}=k_{\text {ala } 2 \rightarrow 3} a_{\mathrm{la} 2}, \\
O_{\text {ala3 } \rightarrow 4}=k_{\text {ala3 } \rightarrow 4} a_{\text {la3 } 3}, & O_{\text {ala } 4 \rightarrow \mathrm{a}}=k_{\text {ala } 4 \rightarrow \mathrm{a}} a_{\mathrm{la} 4} .
\end{array}
$$

Rate constants are in Eq (79). State variables are defined in Eq (87). These outputs are assumed to occur without loss, providing the inputs (aphids stem ${ }^{-1} \mathrm{~d}^{-1}$ ) of $I_{\text {ala2-4 }}$ in Eq (81) and also a developmental input to alate adults [see Eq (57)] of

$$
I_{\text {ala } 4 \rightarrow \text { alaa }}=O_{\text {ala } 4 \rightarrow \mathrm{a}} .
$$

Mortality. These are [with Eqs (11) and (87); cf. Eq (44)] (aphids stem ${ }^{-1} \mathrm{~d}^{-1}$ ):

$$
\begin{aligned}
O_{\text {ala } 1 \rightarrow \text { mort }} & =k_{\text {aph } \rightarrow \text { mort }} a_{\text {la } 1}, \quad O_{\text {ala } 2 \rightarrow \text { mort }}=k_{\text {aph } \rightarrow \text { mort }} a_{\text {la } 2}, \\
O_{\text {ala } 3 \rightarrow \text { mort }} & =k_{\text {aph } \rightarrow \text { mort }} a_{\text {la } 3}, \quad O_{\text {ala } 4 \rightarrow \text { mort }}=k_{\text {aph } \rightarrow \text { mort }} a_{\text {la } 4} . \\
O_{\text {alai } \rightarrow \text { mort }} & =O_{\text {ala } 1 \rightarrow \text { mort }}+O_{\text {ala } 2 \rightarrow \text { mort }}+O_{\text {ala } 3 \rightarrow \text { mort }}+O_{\text {ala } 4 \rightarrow \text { mort }}, \\
O_{\text {ala } \rightarrow \text { mort }} & =O_{\text {alai } \rightarrow \text { mort }}+O_{\text {alaa } \rightarrow \text { mort }} .
\end{aligned}
$$

It is assumed here that the same mortality rate constant applies to alate and apterous instars. The last two of Eq (84) give the total alate instar and the total alate output to mortality.

Pruning. These are [with Eqs (14) and (87); cf. Eq (45)] (aphids stem ${ }^{-1} \mathrm{~d}^{-1}$ ):

$$
\begin{aligned}
O_{\text {ala } 1 \rightarrow \text { prune }} & =k_{\text {le } \rightarrow \text { prune }} a_{\text {la } 1}, \quad O_{\text {ala2 } \rightarrow \text { prune }}=k_{\text {le } \rightarrow \text { prune }} a_{\mathrm{la} 2}, \\
O_{\text {ala } 3 \rightarrow \text { prune }} & =k_{\text {le } \rightarrow \text { prune }} a_{\text {la } 3}, \quad O_{\text {ala } 4 \rightarrow \text { prune }}=k_{\text {le } \rightarrow \text { prune }} a_{\text {la } 4} . \\
O_{\text {alai } \rightarrow \text { prune }} & =O_{\text {ala } 1 \rightarrow \text { prune }}+O_{\text {ala2 } \rightarrow \text { prune }}+O_{\text {ala } 3 \rightarrow \text { prune }}+O_{\text {ala } 4 \rightarrow \text { prune }}, \\
O_{\text {ala } \rightarrow \text { prune }} & =O_{\text {alai } \rightarrow \text { prune }}+O_{\text {alaa } \rightarrow \text { prune }} \\
O_{\text {aph } \rightarrow \text { prune }} & =O_{\text {ala } \rightarrow \text { prune }}+O_{\text {apt } \rightarrow \text { prune }}
\end{aligned}
$$

The last three of $\mathrm{Eq}(85)$ give first, the total alate instar output to pruning, $O_{\text {alai } \rightarrow \text { prune; }}$; next, with the first of Eq (60), total output of alate aphids to pruning, $O_{\text {ala } \rightarrow \text { prune; }}$; and last, the total aphid output to pruning, $O_{\text {aph } \rightarrow \text { prune }}$, using the last of Eq (45). See Section D.5.2 'pruning,' for pruning of apterous aphids. The pruning rate constant $k_{\text {le } \rightarrow \text { prune }}=0 \mathrm{~d}^{-1}$ in the aphid studies presented here [Eq (14)].

\section{D.10.3 Differential equations: juvenile alate (winged) aphids}

Total outputs for each of the four instar pools are [with Eqs (82), (84) and (85)] [cf. Eq $(64)]$

$$
\begin{aligned}
& O_{\text {ala1 }}=O_{\text {ala1 } \rightarrow 2}+O_{\text {ala } 1 \rightarrow \text { mort }}+O_{\text {ala1 } \rightarrow \text { prune }}, \\
& O_{\text {ala2 }}=O_{\text {ala2 } \rightarrow 3}+O_{\text {ala2 } \rightarrow \text { mort }}+O_{\text {ala2 } \rightarrow \text { prune }}, \\
& O_{\text {ala3 }}=O_{\text {ala3 } \rightarrow 4}+O_{\text {ala } 3 \rightarrow \text { mort }}+O_{\text {ala3 } 3 \text { prune }}, \\
& O_{\text {ala4 }}=O_{\text {ala4 } \rightarrow \text { a }}+O_{\text {ala } 4 \rightarrow \text { mort }}+O_{\text {ala4 } 4 \text { prune }}
\end{aligned}
$$


Combining Eqs (81) and (86), the differential equations and initial values for the four state variables are (aphids stem $\left.{ }^{-1} \mathrm{~d}^{-1}\right)[c f$. Eq (47)]:

$$
\frac{\mathrm{d} a_{\mathrm{la} j}}{\mathrm{~d} t}=I_{\mathrm{ala} j}-O_{\mathrm{ala} j}, \text { for } j=1, \ldots, 4 .
$$

At $t=0 \mathrm{~d}, a_{\mathrm{la} 1}=a_{\mathrm{la} 2}=a_{\mathrm{la} 3}=a_{\mathrm{la} 4}=0$ aphids stem $^{-1}$.

\section{D.10.4 Nitrogen and carbon fluxes for the four alate instar pools}

Assume the $\mathrm{N}$ required from phloem is the amount required to increase the $\mathrm{N}$ component of aphid mass entering the next pool. Therefore with Eq (82) [cf. Eq (48)]:

$$
\begin{aligned}
& I_{\text {Nphloem } \rightarrow \text { ala1 }}=O_{\text {ala1 } \rightarrow 2}\left(M_{\text {Nala2 }}-M_{\text {Nala1 }}\right), \\
& I_{\text {Nphloem } \rightarrow \text { ala2 }}=O_{\text {ala2 } \rightarrow 3}\left(M_{\text {Nala3 }}-M_{\text {Nala2 }}\right), \\
& I_{\text {Nphloem } \rightarrow \text { ala3 }}=O_{\text {ala3 } \rightarrow 4}\left(M_{\text {Nala4 }}-M_{\text {Nala3 }}\right), \\
& I_{\text {Nphloem } \rightarrow \text { ala4 }}=O_{\text {ala4 } \rightarrow \text { a }}\left(M_{\text {Nala4 }}-M_{\text {Nala3 }}\right) .
\end{aligned}
$$

Units are: $\mathrm{kg} \mathrm{N}$ stem ${ }^{-1} \mathrm{~d}^{-1}$. Aphid $\mathrm{N}$ contents are in $\mathrm{Eq}(7)$. Total $\mathrm{N}$ taken from the phloem by the four instars (alai) is

$$
I_{\text {Nphloem } \rightarrow \text { alai }}=\sum_{\jmath=1}^{4} I_{\text {Nphloem } \rightarrow \text { ala } \jmath} .
$$

The $\mathrm{C}$ flux from the phloem accompanying this $\mathrm{N}$ flux is [Eq (3), cf. Eq (50)]:

$$
I_{\text {Cphloem } \rightarrow \text { alai }}=r_{\mathrm{CNphloem}} I_{\mathrm{Nphloem} \rightarrow \text { alai }} \text {. }
$$

Respiration flux is $\left(\mathrm{kg} \mathrm{C}\right.$ stem $\left.^{-1} \mathrm{~d}^{-1}\right)$

$$
R_{\text {alai }}=f_{\text {Caph,resp }} I_{\text {Cphloem } \rightarrow \text { alai }} \text {. }
$$

$f_{\text {Caph,resp }}$ is given in Eq (32).

The increase in instar mass from aphid instar development also requires $\mathrm{C}$ from the phloem. The four input $(I)$ components of this and the total phloem $\mathrm{C}$ output to supply these four inputs are [with Eqs (82) and (7); cf. Eq (52)] $\left(\mathrm{kg} \mathrm{C}\right.$ stem $\left.^{-1} \mathrm{~d}^{-1}\right)$ :

$$
\begin{aligned}
I_{\text {Cphloem } \rightarrow \text { ala } 1} & =O_{\text {ala } 1 \rightarrow 2}\left(M_{\text {Cala } 2}-M_{\text {Cala } 1}\right) \\
I_{\text {Cphloem } \rightarrow \text { ala } 2} & =O_{\text {ala } 2 \rightarrow 3}\left(M_{\text {Cala } 3}-M_{\text {Cala } 2}\right), \\
I_{\text {Cphloem } \rightarrow \text { ala } 3} & =O_{\text {ala3 } \rightarrow 4}\left(M_{\text {Cala } 4}-M_{\text {Cala } 3}\right) \\
I_{\text {Cphloem } \rightarrow \text { ala } 4} & =O_{\text {ala4 } \rightarrow \text { a }}\left(M_{\text {Calaa }}-M_{\text {Cala } 4}\right) . \\
I_{\text {Cphloem } \rightarrow \text { alai }} & =I_{\text {Cphloem } \rightarrow \text { ala1 }}+I_{\text {Cphloem } \rightarrow \text { ala } 2}+I_{\text {Cphloem } \rightarrow \text { ala3 }}+I_{\text {Cphloem } \rightarrow \text { ala } 4} .
\end{aligned}
$$

The excess $\mathrm{C}$ is excreted as honeydew (input to the surface litter metabolic pool, Eq (107), see Thornley [34], chapter 5, cf. Eq (53)]:

$$
O_{\text {Calai } \rightarrow \text { hon }}=I_{\text {Cphloem } \rightarrow \text { alai }}-R_{\text {alai }}-O_{\text {Cphloem } \rightarrow \text { alai }} .
$$

This makes use of Eqs (90)-(92).

Mortality gives rise to $\mathrm{C}$ and $\mathrm{N}$ outputs $[\operatorname{Eqs}(7)$ and $(84), c f . \mathrm{Eq}(54)](\mathrm{kg} \mathrm{C}, \mathrm{N}$ stem $\left.^{-1} \mathrm{~d}^{-1}\right)$ :

$$
\begin{gathered}
O_{\text {Calai } \rightarrow \text { mort }}=O_{\text {ala } 1 \rightarrow \text { mort }} M_{\text {Cala } 1}+O_{\text {ala } 2 \rightarrow \text { mort }} M_{\text {Cala } 2} \\
+O_{\text {ala } 3 \rightarrow \text { mort }} M_{\text {Cala } 3}+O_{\text {ala } 4 \rightarrow \text { mort }} M_{\text {Cala } 4}, \\
O_{\text {Nalai } \rightarrow \text { mort }}=O_{\text {ala } 1 \rightarrow \text { mort }} M_{\text {Nala } 1}+O_{\text {ala } 2 \rightarrow \text { mort }} M_{\text {Nala } 2} \\
+O_{\text {ala } 3 \rightarrow \text { mort }} M_{\text {Nala } 3}+O_{\text {ala } 4 \rightarrow \text { mort }} M_{\text {Nala } 4} .
\end{gathered}
$$


The C, N mortality fluxes above are captured in Eqs (108) and (118) and thence in Eqs 930 (112) and (126) on the way to the surface litter cellulose and lignin pools [Eq (127)].

Pruning similarly gives rise to $\mathrm{C}$ and $\mathrm{N}$ outputs [with Eqs (85) and (7), cf. Eq (55)] $\left(\mathrm{kg} \mathrm{C}, \mathrm{N}\right.$ stem $\left.^{-1} \mathrm{~d}^{-1}\right)$ :

$$
\begin{aligned}
& O_{\text {Calai } \rightarrow \text { prune }}=O_{\text {ala1 } \rightarrow \text { prune }} M_{\text {Cala1 }}+O_{\text {ala2 } \rightarrow \text { prune }} M_{\text {Cala2 }} \\
& +O_{\text {ala3 } \rightarrow \text { prune }} M_{\text {Cala3 }}+O_{\text {ala4 } \rightarrow \text { prune }} M_{\text {Cala } 4}, \\
& O_{\text {Nalai } \rightarrow \text { prune }}=O_{\text {ala1 } \rightarrow \text { prune }} M_{\text {Nala1 }}+O_{\text {ala2 } \rightarrow \text { prune }} M_{\text {Nala2 }} \\
& +O_{\text {ala3 } \rightarrow \text { prune }} M_{\text {Nala3 }}+O_{\text {ala4 } \rightarrow \text { prune }} M_{\text {Nala4 }} \text {. }
\end{aligned}
$$

These fluxes are captured in Eqs (110) and (120) and thence in Eqs (112) and (112).

\section{D.11 Aphid mortality, emigration and fecundity}

Here, we calculate total mortality, emigration and fecundity for the aphids.

\section{D.11.1 Mortality}

Aphid fluxes to mortality are summed to give a total of $O_{\text {aph } \rightarrow \text { mort }}$ (aphid number stem $^{-1} \mathrm{~d}^{-1}$ ) of

$$
O_{\text {aph } \rightarrow \text { mort }}=O_{\text {apta } \rightarrow \text { mort }}+O_{\text {apti } \rightarrow \text { mort }}+O_{\text {alaa } \rightarrow \text { mort }}+O_{\text {alai } \rightarrow \text { mort }} .
$$

Here we have used Eqs (12), (44), (59) and (84). Because these fluxes vary greatly both diurnally and seasonally, it can be helpful to take yearly accumulations (ya) with

$$
\begin{aligned}
O_{\text {aph } \rightarrow \text { mortya }} & =\int_{t-365}^{t} O_{\text {aph } \rightarrow \text { mort }} \mathrm{d} t, \\
a_{\text {phya }} & =\int_{t-365}^{t} a_{\text {ph }} \frac{\mathrm{d} t}{365} .
\end{aligned}
$$

The additional subscript ya denotes yearly accumulation for rate variables such as $O_{\text {aph } \rightarrow \text { mort }}$ or a yearly average for non-rate variables such as $a_{\mathrm{ph}} . O_{\text {aph } \rightarrow \text { mortya now has }}$ units of aphid number stem ${ }^{-1} \mathrm{y}^{-1} \cdot a_{\mathrm{phya}}$ is a yearly average of $a_{\mathrm{ph}}$, with units of aphid number stem ${ }^{-1}$.

\section{D.11.2 Emigration}

The emigration flux is $O_{\text {alaa } \rightarrow \text { emi }}\left(\right.$ aphids stem ${ }^{-1} \mathrm{~d}^{-1}$ ) [Eq (62)]. Total output from the alate adult pool is $O_{\text {alaa }}[\mathrm{Eq}(63)]$. The mortality flux from this pool is $O_{\text {alaa } \rightarrow \text { mort }}$ [Eq (59)]. In Fig D.9 the fractional output fluxes to mortality and to emigration are shown. In the absence of pruning [Eq (63)] the two fractional variables defined in Eq (99) add up to unity. Emigration peaks in late summer, when the adult alate population is maximum (Fig D.9) and air temperature is also favourable (Fig 3A).

Because, as far as the local population is concerned, emigration is equivalent to mortality, we also calculate the flux to 'mortality + emigration', which includes the emigration flux from alate adults $\left[O_{\text {alaa } \rightarrow \mathrm{emi}}, \mathrm{Eq}(62)\right]$. Using an obvious notation, therefore

$$
\begin{aligned}
O_{\text {alaa } \rightarrow \text { mortemi }} & =O_{\text {alaa } \rightarrow \text { mort }}+O_{\text {alaa } \rightarrow \text { emi }} . \\
O_{\text {alaa } \rightarrow \text { mortemiya }} & =\int_{t-365}^{t} O_{\text {alaa } \rightarrow \text { mortemi }} \mathrm{d} t .
\end{aligned}
$$


The terms Eq (98a) have units of aphids stem ${ }^{-1} \mathrm{~d}^{-1}$; in Eq (98b) we give the yearly accumulations (aphids stem ${ }^{-1} \mathrm{y}^{-1}$ ). In fact, the emigration flux is mostly small compared to the total aphid mortality flux (Fig D.9). In Eq (98) and in the simulations shown in Fig D.9, mortality and emigration are the only fluxes from the alate adult pool $[\mathrm{Eq}(63)]$ as the pruning fluxes are zero [Eq (14)]. The (dimension-free) fractional outputs are

$$
f_{\text {Oalaa } \rightarrow \text { emi }}=\frac{O_{\text {alaa } \rightarrow \text { emi }}}{O_{\text {alaa }}}, f_{\text {Oalaa } \rightarrow \text { mort }}=\frac{O_{\text {alaa } \rightarrow \text { mort }}}{O_{\text {alaa }}} .
$$

The fractional fate of alate adults is drawn in Fig D.9. Aphids in the alate adult pool, $a_{\text {laa }}$, may either die or emigrate [Fig 2 and Eq (63). The fractions are calculated in Eq (99). After an initial transient the fraction emigrating, $f_{\text {Oalaa } \rightarrow \text { emi }}$ drops to a few percent and then peaks as the temperature rises [Fig 3A, Eq (17), Fig D.6, default temperature response]. Mortality rate is close to zero at these moderate temperatures [Eqs (11) and (9), Fig D.3]. Alate adult numbers per stem, $a_{\text {laa }}$, increase each year as leaf area available to the aphids, $A_{\text {leaf,aph }}$, increases [Eq (5)].

\section{D.11.3 Fecundity}

Total offspring production rate from apterous and alate adults (1st instar aphids stem ${ }^{-1}$ $\left.\mathrm{d}^{-1}\right)$ is

$$
\begin{aligned}
O_{\text {aph } \rightarrow \text { fec }} & =O_{\text {apta } \rightarrow \text { ala } 1}+O_{\text {apta } \rightarrow \text { apt } 1}+O_{\text {alaa } \rightarrow \text { ala } 1}+O_{\text {alaa } \rightarrow \text { apt } 1}, \\
O_{\text {aph } \rightarrow \text { fecya }} & =\int_{t-365}^{t} O_{\text {aph } \rightarrow \text { fec }} \mathrm{d} t .
\end{aligned}
$$

Here we utilized Eqs (30) and (74). Eq (100a) gives the instantaneous rate and Eq (100b) the yearly accumulation (1st instar aphids stem $\left.{ }^{-1} \mathrm{y}^{-1}\right)$.

\section{D.11.4 Total aphid number per stem, $a_{\mathrm{ph}}$}

The ten state variable differential-equation components of $a_{\mathrm{ph}}$ (Fig 2) of Eq 4, namely Eqs (64), (87), (16) and (47) are added to give $\mathrm{d} a_{\mathrm{ph}} / \mathrm{d} t$ :

$$
\frac{\mathrm{d} a_{\mathrm{ph}}}{\mathrm{d} t}=\frac{\mathrm{d} a_{\text {alaa }}}{\mathrm{d} t}+\sum_{\jmath=1}^{4} \frac{\mathrm{d} a_{\text {ala }}}{\mathrm{d} t}+\frac{\mathrm{d} a_{\text {apta }}}{\mathrm{d} t}+\sum_{j=1}^{4} \frac{\mathrm{d} a_{\text {apt }}}{\mathrm{d} t} .
$$

Putting immigration, $I_{\mathrm{imm} \rightarrow \text { alaa }}=0[\mathrm{Eq}(56)]$ and noting that alate adults $\left(a_{\text {laa }}\right)$ are the only morph able to emigrate, therefore

$$
\frac{\mathrm{d} a_{\mathrm{ph}, \mathrm{chk}}}{\mathrm{d} t}=O_{\mathrm{aph} \rightarrow \mathrm{fec}}-O_{\mathrm{aph} \rightarrow \mathrm{mort}}-O_{\text {alaa } \rightarrow \mathrm{emi}}-O_{\mathrm{aph} \rightarrow \text { prune }}
$$

Units are aphids stem ${ }^{-1} \mathrm{~d}^{-1}$. Here we make use of Eqs (100), (96), (62) and (85). The equality of the values of Eqs (101) and (102) gives a useful check on the accuracy of the programming.

\section{D.12 Aphid sub-model - $\mathrm{C}$ and $\mathrm{N}$ balances}

In this section the inputs and outputs of the whole aphid subsystem are summarized. This has two purposes. First, it is a useful check that the model has been consistently formulated mathematically and is programmed correctly. Second, in long-term ecosystem studies, quite small fluxes are important, as they can lead to degradation, or otherwise, of the ecosystem. These are now made explicit. 


\section{D.12.1 Carbon inputs: phloem, immigration}

There are two $\mathrm{C}$ inputs to the aphid sub-model, from the phloem and from possible immigration of alates. The C input from the phloem is [Eqs (90), (50), (69) and (24)]

$$
\begin{aligned}
& I_{\text {Cphloem } \rightarrow \text { aph }}=I_{\text {Cphloem } \rightarrow \text { alai }}+I_{\text {Cphloem } \rightarrow \text { apti }}+I_{\text {Cphloem } \rightarrow \text { alaa }}+I_{\text {Cphloem } \rightarrow \text { apta }}, \\
& I_{\text {Cphloem } \rightarrow \text { aph }, \mathrm{m} 2}=n_{\text {stems }} I_{\text {Cphloem } \rightarrow \text { aph }} .
\end{aligned}
$$

The first equation is in units of $\mathrm{kg} \mathrm{C} \mathrm{stem}^{-1} \mathrm{~d}^{-1}$, the second, $\mathrm{kg} \mathrm{C}\left(\mathrm{m}^{2} \text { ground }\right)^{-1} \mathrm{~d}^{-1}$. 992 $n_{\text {stems }}$ is the stem density (number of stems $\mathrm{m}^{-2}$ ), a state variable of the efm [Eq (1)].

Immigration gives $\mathrm{C}$ fluxes of [Eqs (7) and (56)]

$$
I_{\text {Cimm } \rightarrow \text { alaa }}=I_{\text {imm } \rightarrow \text { alaa }} M_{\text {Calaa }}, \quad I_{\text {Cimm } \rightarrow \text { alaa }, \mathrm{m} 2}=n_{\text {stems }} I_{\text {Cimm } \rightarrow \text { alaa }} .
$$

The first equation is in units of $\mathrm{kg} \mathrm{C}$ stem ${ }^{-1} \mathrm{~d}^{-1}$, the second, $\mathrm{kg} \mathrm{C}\left(\mathrm{m}^{2} \text { ground }\right)^{-1} \mathrm{~d}^{-1}$.

Total C inputs to the aphid sub-model are [Eqs (103) and (104)]

$$
I_{\text {Caph }}=I_{\text {Cphloem } \rightarrow \text { aph }}+I_{\text {Cimm } \rightarrow \text { alaa }}, \quad I_{\text {Caph }, \mathrm{m} 2}=n_{\text {stems }} I_{\text {Caph }},
$$

with units of $\mathrm{kg} \mathrm{C}$ stem ${ }^{-1} \mathrm{~d}^{-1}$ and $\mathrm{kg} \mathrm{C}\left(\mathrm{m}^{2} \text { ground }\right)^{-1} \mathrm{~d}^{-1}$.

\section{D.12.2 Carbon outputs: respiration, honeydew, mortality, emigration, pruning, thinning}

There are outputs via respiration, honeydew, mortality, emigration, pruning and thinning.

Aphid respiration which produces $\mathrm{CO}_{2}$ gives $\mathrm{C}$ fluxes of [Eqs (76), (91), (32), (51)]

$$
\begin{aligned}
O_{\mathrm{Caph} \rightarrow \mathrm{CO} 2} & =R_{\text {alaa }}+R_{\text {alai }}+R_{\text {apta }}+R_{\text {apti }}, \\
O_{\mathrm{Caph} \rightarrow \mathrm{CO} 2, \mathrm{~m} 2} & =n_{\text {stems }} O_{\mathrm{Caph} \rightarrow \mathrm{CO} 2} .
\end{aligned}
$$

Units are $\mathrm{kg} \mathrm{C}$ stem ${ }^{-1} \mathrm{~d}^{-1}$ and $\mathrm{kg} \mathrm{C}\left(\mathrm{m}^{2} \text { ground }\right)^{-1} \mathrm{~d}^{-1}$, respectively.

Honeydew production [Eqs $(78),(93),(34),(53)$ ] gives an output, $O_{\mathrm{Caph} \rightarrow \mathrm{hon}, \mathrm{m} 2}$, which is input without loss to the surface litter metabolic pool [Eq (12)] ([34], figure 5.1, $\left.C_{\text {surf-li,met }}\right)$ :

$$
\begin{aligned}
O_{\text {Caph } \rightarrow \text { hon }} & =O_{\text {Calaa } \rightarrow \text { hon }}+O_{\text {Calai } \rightarrow \text { hon }}+O_{\text {Capta } \rightarrow \text { hon }}+O_{\text {Capti } \rightarrow \text { hon }}, \\
O_{\text {Caph } \rightarrow \text { hon }, \mathrm{m} 2} & =n_{\text {stems }} O_{\text {Caph } \rightarrow \text { hon }} .
\end{aligned}
$$

Units are $\mathrm{kg} \mathrm{C}$ stem ${ }^{-1} \mathrm{~d}^{-1}$ (Eq (107a)) and $\mathrm{kg} \mathrm{C}\left(\mathrm{m}^{2} \text { ground }\right)^{-1} \mathrm{~d}^{-1}$ (Eq (107b)).

Mortality of aphids gives rise to C fluxes of [Eqs (59), (94), (12) and (54)]

$$
\begin{aligned}
O_{\text {Caph } \rightarrow \text { mort }} & =O_{\text {Calaa } \rightarrow \text { mort }}+O_{\text {Calai } \rightarrow \text { mort }}+O_{\text {Capta } \rightarrow \text { mort }}+O_{\text {Capti } \rightarrow \text { mort }}, \\
O_{\text {Caph } \rightarrow \text { mort }, \mathrm{m} 2} & =n_{\text {stems }} O_{\text {Caph } \rightarrow \text { mort }} .
\end{aligned}
$$

Units are as in Eq (107). This flux is divided equally between the surface litter cellulose and lignin pools [Eq (126) and Eq (127); figure 5.1 in [34]].

Emigration of adult alates gives rise to a output C flux $\left(\mathrm{kg} \mathrm{C} \mathrm{stem}{ }^{-1} \mathrm{~d}^{-1}\right)$ of $O_{\text {Calaa } \rightarrow \text { emi }}[\mathrm{Eq}(62)]$ and a $\mathrm{C}$ flux per unit area ground of

$$
O_{\text {Calaa } \rightarrow \text { emi }, \mathrm{m} 2}=n_{\text {stems }} O_{\text {Calaa } \rightarrow \text { emi }} \text {. }
$$

Pruning the trees gives an output C flux of [Eqs (60), (95), (14), (55)]

$$
\begin{aligned}
& O_{\text {Caph } \rightarrow \text { prune }}=O_{\text {Calaa } \rightarrow \text { prune }}+O_{\text {Calai } \rightarrow \text { prune }}+O_{\text {Capta } \rightarrow \text { prune }}+O_{\text {Capti } \rightarrow \text { prune }}, \\
& O_{\text {Caph } \rightarrow \text { prune, } 22}=n_{\text {stems }} O_{\text {Caph } \rightarrow \text { prune }} .
\end{aligned}
$$


Again, units are $\mathrm{kg} \mathrm{C}$ stem ${ }^{-1} \mathrm{~d}^{-1}$ and $\mathrm{kg} \mathrm{C}\left(\mathrm{m}^{2} \text { ground }\right)^{-1} \mathrm{~d}^{-1}$. As with the mortality fluxes of Eq (108), it is assumed that pruning produces a flux of dead aphids into the surface litter cellulose and lignin pools [Eqs (126) and (127); figure 5.1 in [34]].

Thinning, which is applied in forest plantation management, removes whole stems (Section 4.2). It does not affect aphid numbers per stem. However, aphids on removed stems are assumed to join the surface litter, together with the foliage on the removed stems (some of the branches and stems may be taken away as timber products). The rate of stem loss per unit ground area is specified by the management regime in the forest model (Section 4.2). It is $O_{\text {nstems } \rightarrow \text { th }}\left[\mathrm{Eq}(1)\right.$, stems $\left.\mathrm{m}^{-2} \mathrm{~d}^{-1}\right]$. This quantity is zero most of the time, but it is non-zero on the days when the plantation is thinned by an amount specified. Multiplying by $C_{\text {aph }}$ [Eq (6), $\mathrm{kg}$ aphid $\mathrm{C}$ per stem], this leads to an aphid $\mathrm{C}$ output flux per unit ground area of $\left(\operatorname{kg~C~m} \mathrm{m}^{-1}\right)$

$$
O_{\mathrm{Caph} \rightarrow \mathrm{th}, \mathrm{m} 2}=O_{\text {nstems } \rightarrow \mathrm{th}} C_{\mathrm{aph}} .
$$

This output is input to the soil surface litter inputs in Eq (126).

Total aphid C outputs are [with Eqs (106)-(108), (110), (62) and (111)]

$$
\begin{aligned}
& O_{\mathrm{Caph}}=O_{\mathrm{Caph} \rightarrow \mathrm{CO} 2}+O_{\mathrm{Caph} \rightarrow \mathrm{hon}}+O_{\mathrm{Caph} \rightarrow \text { mort }}+O_{\mathrm{Caph} \rightarrow \text { prune }}+O_{\mathrm{Caph} \rightarrow \mathrm{emi}} . \\
& O_{\mathrm{Caph}, \mathrm{m} 2}=n_{\text {stems }} O_{\mathrm{Caph}}+O_{\mathrm{Caph} \rightarrow \mathrm{th}, \mathrm{m} 2} .
\end{aligned}
$$

The first equation here has units of $\mathrm{kg} \mathrm{C}$ stem $^{-1} \mathrm{~d}^{-1}$; the second units of $\mathrm{kg} \mathrm{C}\left(\mathrm{m}^{2}\right.$ ground $)^{-1} \mathrm{~d}^{-1}$.

\section{D.12.3 Carbon balance}

A consistency check is to calculate the rate of change of aphid $\mathrm{C}$ two ways. First by summing the differential Eqs (64), (87)), (16) and (47), with Eq (7) for the first equation and Eqs (1) and (6) for the second equation:

$$
\begin{aligned}
& \frac{\mathrm{d} C_{\text {aph }}}{\mathrm{d} t}=M_{\text {Calaa }} \frac{\mathrm{d} a_{\text {laa }}}{\mathrm{d} t}+\sum_{\jmath=1}^{4} M_{\text {Cala } \jmath} \frac{\mathrm{d} a_{\text {la } \jmath}}{\mathrm{d} t}+M_{\text {Capta }} \frac{\mathrm{d} a_{\mathrm{pta}}}{\mathrm{d} t}+\sum_{\jmath=1}^{4} M_{\text {Capt } \jmath} \frac{\mathrm{d} a_{\mathrm{pt} \jmath}}{\mathrm{d} t} . \\
& \frac{\mathrm{d} C_{\text {aph }, \mathrm{m} 2}}{\mathrm{~d} t}=n_{\text {stems }} \frac{\mathrm{d} C_{\mathrm{aph}}}{\mathrm{d} t}+C_{\mathrm{aph}} \frac{\mathrm{d} N_{\mathrm{stems}}}{\mathrm{d} t} .
\end{aligned}
$$

These were compared (successfully) with the same (check $=$ chk) quantities calculated with [Eqs (105) and (112)]

$$
\begin{aligned}
\frac{\mathrm{d} C_{\mathrm{aph}, \mathrm{chk}}}{\mathrm{d} t} & =I_{\mathrm{Caph}}-O_{\mathrm{Caph}}, \\
\frac{\mathrm{d} C_{\mathrm{aph}, \mathrm{m} 2, \mathrm{chk}}}{\mathrm{d} t} & =I_{\mathrm{Caph}, \mathrm{m} 2}-O_{\mathrm{Caph}, \mathrm{m} 2} .
\end{aligned}
$$

\section{D.12.4 Nitrogen inputs: phloem, immigration}

The procedure from Eqs (103)-(114) for $\mathrm{C}$ is repeated for $\mathrm{N}$. There are the same two $\mathrm{N}$ inputs [cf. Eqs (103)-(105)], from the phloem and via immigration.

From the phloem, therefore, with Eqs (89), (49), (69), (24) and (1) for $n_{\text {stems }}$ :

$$
\begin{aligned}
& I_{\mathrm{Nphloem} \rightarrow \mathrm{aph}}=I_{\mathrm{Nphloem} \rightarrow \text { alai }}+I_{\mathrm{Nphloem} \rightarrow \text { apti }}+I_{\text {Nphloem } \rightarrow \text { alaa }}+I_{\text {Nphloem } \rightarrow \text { apta }} . \\
& I_{\text {Nphloem } \rightarrow \text { aph }, \mathrm{m} 2}=n_{\text {stems }} I_{\text {Nphloem } \rightarrow \text { aph }} .
\end{aligned}
$$

Units are $\mathrm{kg} \mathrm{N}$ stem ${ }^{-1} \mathrm{~d}^{-1}$ and $\mathrm{kg} \mathrm{N}\left(\mathrm{m}^{2} \text { ground }\right)^{-1} \mathrm{~d}^{-1}$. 
Immigration gives $\mathrm{N}$ fluxes of [Eqs (7) and (56)]:

$$
I_{\mathrm{Nimm} \rightarrow \text { alaa }}=I_{\mathrm{imm} \rightarrow \text { alaa }} M_{\text {Nalaa }} ; I_{\mathrm{Nimm} \rightarrow \text { alaa }, \mathrm{m} 2}=n_{\text {stems }} I_{\mathrm{Naph}} .
$$

Units as in Eq (115) .

Total N inputs to the aphid sub-model are [with Eqs (115), (116) and (1)]

$$
I_{\text {Naph }}=I_{\text {Nphloem } \rightarrow \text { aph }}+I_{\text {Nimm } \rightarrow \text { alaa }}, \quad I_{\text {Naph }, \mathrm{m} 2}=n_{\text {stems }} I_{\text {Naph }} .
$$

Units are $\mathrm{kg} \mathrm{N}$ stem ${ }^{-1} \mathrm{~d}^{-1}$ and $\mathrm{kg} \mathrm{N}\left(\mathrm{m}^{2} \text { ground }\right)^{-1} \mathrm{~d}^{-1}$.

\section{D.12.5 Nitrogen outputs: mortality, emigration, pruning, thinning}

There are outputs to mortality, emigration, pruning and thinning.

First, mortality of aphids gives rise to N fluxes of [Eqs (59), (94), (13), (54) and (1)]

$$
\begin{aligned}
O_{\text {Naph } \rightarrow \text { mort }} & =O_{\text {Nala } \rightarrow \text { mort }}+O_{\text {Nalai } \rightarrow \text { mort }}+O_{\text {Napta } \rightarrow \text { mort }}+O_{\text {Napti } \rightarrow \text { mort }}, \\
O_{\text {Naph } \rightarrow \text { mort }, \mathrm{m} 2} & =n_{\text {stems }} O_{\text {Naph } \rightarrow \text { mort }} .
\end{aligned}
$$

Units are $\mathrm{kg} \mathrm{N}$ stem ${ }^{-1} \mathrm{~d}^{-1}$ and $\mathrm{kg} \mathrm{N}\left(\mathrm{m}^{2} \text { ground }\right)^{-1} \mathrm{~d}^{-1}$. This dead aphid $\mathrm{N}$ flux is divided between the surface litter metabolic N, cellulose and lignin pools (Eqs (126)-(128); figure 5.1 in [34]).

Next emigration of adult alates gives rise to an $\mathrm{N}$ flux per stem of $O_{\mathrm{Nalaa} \rightarrow \mathrm{emi}}[\mathrm{Eq}$ (62)] and an N flux per unit area ground of [for $n_{\text {stems }}$, see Eq (1)]:

$$
O_{\text {Nalaa } \rightarrow \text { emi,m2 }}=n_{\text {stems }} O_{\text {Nalaa } \rightarrow \text { emi }} \text {. }
$$

Pruning the trees gives an output N flux of [Eqs (60), (95), (14) and (55)]

$$
\begin{aligned}
O_{\text {Naph } \rightarrow \text { prune }} & =O_{\text {Nala } \rightarrow \text { prune }}+O_{\text {Nalai } \rightarrow \text { prune }}+O_{\text {Napta } \rightarrow \text { prune }}+O_{\text {Napti } \rightarrow \text { prune }}, \\
O_{\text {Naph } \rightarrow \text { prune,m2 }} & =n_{\text {stems }} O_{\text {Naph } \rightarrow \text { prune }} .
\end{aligned}
$$

Units are $\mathrm{kg} \mathrm{N}$ stem ${ }^{-1} \mathrm{~d}^{-1}$ and $\mathrm{kg} \mathrm{N}\left(\mathrm{m}^{2} \text { ground }\right)^{-1} \mathrm{~d}^{-1}$.

Thinning gives rise to an aphid $\mathrm{N}$ output flux per unit ground area of $[\mathrm{Eq}(6)$, see discussion before $\mathrm{Eq}(111)]\left(\mathrm{kg} \mathrm{N} \mathrm{m}^{-2} \mathrm{~d}^{-1}\right)$

$$
O_{\mathrm{Naph} \rightarrow \mathrm{th}, \mathrm{m} 2}=O_{\text {nstems } \rightarrow \text { th }} N_{\text {aph }} .
$$

Total aphid N outputs are [with Eqs (118), (120), (62), (1) and (121)]

$$
\begin{aligned}
O_{\mathrm{Naph}} & =O_{\mathrm{Naph} \rightarrow \mathrm{mort}}+O_{\mathrm{Naph} \rightarrow \mathrm{prune}}+O_{\mathrm{Naph} \rightarrow \mathrm{emi}}, \\
O_{\mathrm{Naph}, \mathrm{m} 2} & =n_{\text {stems }} O_{\text {Naph }}+O_{\mathrm{Naph} \rightarrow \mathrm{th}, \mathrm{m} 2} .
\end{aligned}
$$

Units are $\mathrm{kg} \mathrm{N}$ stem ${ }^{-1} \mathrm{~d}^{-1}$ and $\mathrm{kg} \mathrm{N}\left(\mathrm{m}^{2} \text { ground }\right)^{-1} \mathrm{~d}^{-1}$. These outputs are used in Eq ${ }_{1058}$ (124) for consistency checking and in Eq (126) for calculating inputs to the surface litter $\quad 1059$ pools.

\section{D.12.6 N balance}

The same consistency check is applied to $\mathrm{N}$ as for $\mathrm{C}$ [Eqs (113) and (114)].

$$
\begin{aligned}
& \frac{\mathrm{d} N_{\text {aph }}}{\mathrm{d} t}=M_{\text {Nalaa }} \frac{\mathrm{d} a_{\text {laa }}}{\mathrm{d} t}+\sum_{\jmath=1}^{4} M_{\text {Nala }} \frac{\mathrm{d} a_{\text {la } \jmath}}{\mathrm{d} t}+M_{\text {Napta }} \frac{\mathrm{d} a_{\mathrm{pta}}}{\mathrm{d} t}+\sum_{\jmath=1}^{4} M_{\text {Napt } \jmath} \frac{\mathrm{d} a_{\mathrm{pt} \jmath}}{\mathrm{d} t} . \\
& \frac{\mathrm{d} N_{\text {aph }, \mathrm{m} 2}}{\mathrm{~d} t}=n_{\text {stems }} \frac{\mathrm{d} N_{\text {aph }}}{\mathrm{d} t}+N_{\text {aph }} \frac{\mathrm{d} N_{\text {stems }}}{\mathrm{d} t} .
\end{aligned}
$$




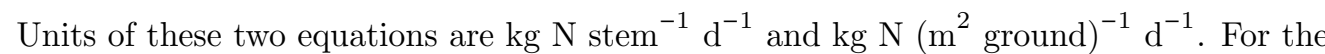
first of these sum the differential Eqs (64), (87), (16) and (47) and apply Eq (7); for the second use Eqs (1) and (6). These were compared (successfully) with those calculated with Eqs (117) and (122).

$$
\begin{aligned}
\frac{\mathrm{d} N_{\text {aph,chk }}}{\mathrm{d} t} & =I_{\mathrm{Naph}}-O_{\mathrm{Naph}}, \\
\frac{\mathrm{d} N_{\mathrm{aph}, \mathrm{m} 2, \mathrm{chk}}}{\mathrm{d} t} & =I_{\mathrm{Naph}, \mathrm{m} 2}-O_{\mathrm{Naph}, \mathrm{m} 2} .
\end{aligned}
$$

\section{D.13 Soil sub-model inputs from: mortality, pruning and thinning}

The $\mathrm{C}$ input to the surface litter metabolic $\mathrm{C}$ pool ([34], figure 5.1) from honeydew is [Eq (107)] $\left(\mathrm{kg} \mathrm{C} \mathrm{m}{ }^{-2} \mathrm{~d}^{-1}\right)$ :

$$
I_{\mathrm{Caph} \rightarrow \text { surf-li,met }}=O_{\mathrm{Caph} \rightarrow \mathrm{hon}, \mathrm{m} 2} .
$$

The $\mathrm{C}$ inputs to the cellulose and lignin pools are calculated by first totalling the $\mathrm{C}$ and $\mathrm{N}$ dead aphid fluxes from mortality [Eqs (108) and (118)], pruning [Eqs (110) and

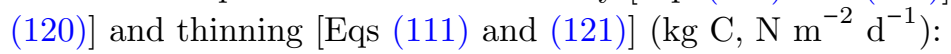

$$
\begin{aligned}
& I_{\text {Caph } \rightarrow \text { surf-li }}=O_{\mathrm{Caph} \rightarrow \text { mort }, \mathrm{m} 2}+O_{\mathrm{Caph} \rightarrow \text { prune }, \mathrm{m} 2}+O_{\mathrm{Caph} \rightarrow \mathrm{th}, \mathrm{m} 2}, \\
& I_{\mathrm{Naph} \rightarrow \text { surf-li }}=O_{\mathrm{Naph} \rightarrow \mathrm{mort}, \mathrm{m} 2}+O_{\mathrm{Naph} \rightarrow \text { prune,m2 }}+O_{\mathrm{Naph} \rightarrow \mathrm{th}, \mathrm{m} 2} .
\end{aligned}
$$

The C flux is partitioned equally between the cellulose and lignin pools:

$$
\begin{aligned}
I_{\text {Caph } \rightarrow \text { surf-li,cel }} & =f_{\text {Caph,cel }} I_{\text {Caph } \rightarrow \text { surf-li }}, \\
I_{\text {Caph } \rightarrow \text { surf-li,lig }} & =\left(1-f_{\text {Caph,cel }}\right) I_{\text {Caph } \rightarrow \text { surf-li }}, \\
f_{\text {Caph,cel }} & =0.5
\end{aligned}
$$

$f_{\text {Caph,cel }}$ is the fraction of $\mathrm{C}$ in dead aphids assigned to the surface litter cellulose pool, the remainder entering the lignin pool.

The $\mathrm{N}$ flux is handled rather differently, because of the assumption that the cellulose and lignin litter pools have a constant C:N ratio ([34], p. 75; p. 85, equation 5.1c). The $\mathrm{N}$ flux required to satisfy this fixed C:N ratio is subtracted from the total dead aphid $\mathrm{N}$ flux and the remainder is put into the surface litter metabolic pool. Therefore, with Eqs (127) and (126):

$$
\begin{aligned}
I_{\mathrm{Naph} \rightarrow \text { surf-li,cel }} & =\frac{I_{\mathrm{Caph} \rightarrow \text { surf-li,cel }}}{R_{\mathrm{CN}, \text { cel }}}, \quad I_{\mathrm{Naph} \rightarrow \text { surf-li,lig }}=\frac{I_{\mathrm{Caph} \rightarrow \text { surf-li,lig }}}{r_{\mathrm{CN}, \mathrm{cel}}}, \\
I_{\mathrm{Naph} \rightarrow \text { surf-li,met }} & =I_{\mathrm{Naph} \rightarrow \text { surf-li }}-I_{\mathrm{Naph} \rightarrow \text { surf-li,cel }}-I_{\mathrm{Naph} \rightarrow \text { surf-li,lig. }} . \\
r_{\mathrm{CN}, \mathrm{cel}} & =150, \quad r_{\mathrm{CN}, \mathrm{cel}}=100 \mathrm{~kg} \mathrm{C}(\mathrm{kg} \mathrm{N})^{-1} .
\end{aligned}
$$

The cellulose and lignin C:N ratios are 150 and $100 \mathrm{~kg} \mathrm{C}(\mathrm{kg} \mathrm{N})^{-1}$.

\section{D.14 Aphid $\mathrm{C}$ and $\mathrm{N}$ at the end of a rotation}

At the end of a rotation, the plantation is clear-felled. It is assumed that the aphid $\mathrm{C}$ and $\mathrm{N}$ are similar to foliage structural $\mathrm{C}$ and $\mathrm{N}$ and they are added to the surface litter structural $\mathrm{C}$ and $\mathrm{N}$ pools on this basis, before the next rotation is begun. See figure 5.1 and equations 5.1b,c of Thornley ([34], p. 76, p. 85). 
When initializing for the next rotation, the initial $\mathrm{C}$ and $\mathrm{N}$ contents of the aphids $\left(C_{\text {aph }}, N_{\text {aph }}\right.$ at $t=0$, expressed per unit ground area) are subtracted from the surface litter metabolic $\mathrm{C}$ and $\mathrm{N}$ pools, so that small amounts of $\mathrm{C}$ and $\mathrm{N}$ are not added at the beginning of every rotation when infestation via alate immigration occurs. However this is not important in the present studies as the initial values for the soil and litter sub-model are obtained by multiple rotations in the absence of aphids.

\section{Appendix E Summary of symbols used in the model} 1094

Tab E.1. Symbols and definitions. Notation and abbreviations: equation numbers of significant occurrence are given. $\mathrm{DM}$ denotes dry matter, $\mathrm{C}$ denotes carbon, and $\mathrm{N}$ denotes nitrogen.

\begin{tabular}{|c|c|c|}
\hline \multicolumn{3}{|c|}{ Aphid sub-model state variables (Fig 2) } \\
\hline Symbol & Definition & Values and Units \\
\hline$a_{\mathrm{la \jmath},}, \jmath=1, \ldots 4$ & Alate (winged) instars [Eqs (4), (87)] & 0 aphids stem ${ }^{-1}$ \\
\hline$a_{\text {laa }}$ & Alate adults [Eqs (4), (64)] & 10 aphids stem ${ }^{-1}$ \\
\hline$a_{\mathrm{pt} \jmath}, \jmath=1, \ldots 4$ & Apterous (wingless) instars [Eqs (4), (47)] & 0 aphids stem ${ }^{-1}$ \\
\hline$a_{\text {pta }}$ & Apterous adults [Eqs (4), (16)] & 0 aphids stem $^{-1}$ \\
\hline \multicolumn{3}{|c|}{ Parameters } \\
\hline Symbol & Definition & Values and Units \\
\hline$c_{\text {aph,mort,skew }}$ & $\begin{array}{l}\text { Skewness parameter for temperature dependence of } \\
\text { mortality }[\mathrm{Eq}(9)]\end{array}$ & 0.2 (dimensionless) \\
\hline$f_{\text {Caph,cel }}$ & $\begin{array}{l}\text { Fraction of } \mathrm{C} \text { in dead aphids assigned to surface litter } \\
\text { cellulose }[\mathrm{Eq}(127)]\end{array}$ & 0.5 \\
\hline$f_{\text {Caph,resp }}$ & Fraction of aphid $\mathrm{C}$ from phloem input respired [Eq (32)] & 0.5 \\
\hline$f_{\mathrm{Naph}, \mathrm{dev}, \min }$ & $\begin{array}{l}\text { Fractional development rate due to low N phloem [Eq } \\
(36)]\end{array}$ & 0.9 \\
\hline$I_{\text {Npalaa,max } 20}, I_{\text {Npapta,max } 20}$ & $\begin{array}{l}\text { Maximum processing (p) } \mathrm{N} \text { intake rate at } 20{ }^{\circ} \mathrm{C} \text { per } \\
\text { alate, apterous adult [Eqs }(21),(66)]\end{array}$ & $\begin{array}{l}2 \times 10^{-6} \mathrm{~kg} \mathrm{~N} \\
\text { aphid }^{-1} \mathrm{~d}^{-1}\end{array}$ \\
\hline$K_{\mathrm{Naph}, \mathrm{dev}}, K_{\mathrm{Naph}, \mathrm{mort}}$ & $\begin{array}{l}\text { Michaelis-Menten constants for nutrition-dependent } \\
\text { development [Eq (36)], mortality [Eq (10)] }\end{array}$ & $1 \mathrm{~kg} \mathrm{~N} \mathrm{~m}{ }^{-3}$ \\
\hline $\begin{array}{l}K_{\text {Nala }}, K_{\text {Napt }}, K_{\text {Tala }}, K_{\text {Tapt }}, \\
K_{\rho \text { aph,ala }}, K_{\rho \text { aph,apt }}\end{array}$ & $\begin{array}{l}\text { Michaelis-Menten constants for effects of nutrition, } \\
\text { temperature and aphid density on the alate/apterous } \\
\text { fractions in offspring }[\text { Eqs }(72),(27),(70),(25),(71) \text {, } \\
(26)]\end{array}$ & $\begin{array}{l}4 \mathrm{~kg} \mathrm{~N} \mathrm{~m}{ }^{-3}, 10{ }^{\circ} \mathrm{C}, \\
1000 \text { aphids }\left(\mathrm{m}^{2} \text { leaf }\right. \\
\text { area })^{-1}\end{array}$ \\
\hline $\begin{array}{l}k_{\text {ala } 1 \rightarrow 2,20}, k_{\text {ala } 2 \rightarrow 3,20} \\
k_{\text {ala } 3 \rightarrow 4,20}, k_{\text {ala } 4 \rightarrow \mathrm{a}, 20} \\
k_{\text {apt } 1 \rightarrow 2,20}, k_{\text {apt } 2 \rightarrow 3,20} \\
k_{\text {apt } 3 \rightarrow 4,20}, k_{\text {apt } 4 \rightarrow \mathrm{a}, 20}\end{array}$ & $\begin{array}{l}\text { Development rate constants of alate and apterous instars } \\
\text { at } 20{ }^{\circ} \mathrm{C}[\mathrm{Eqs}(79),(38)]\end{array}$ & $\begin{array}{l}0.18,0.2125, \\
0.242857 ; 0.283 ; 0.22, \\
0.25,0.285714 ; 0.33^{*} \\
\mathrm{~d}^{-1}, * \text { denotes } \\
\text { recurring }\end{array}$ \\
\hline & & ontinued on next page \\
\hline
\end{tabular}




\begin{tabular}{|c|c|c|}
\hline Symbol & Definition & Values and Units \\
\hline$k_{\text {alaa } \rightarrow \text { emi } 20}$ & $\begin{array}{l}\text { Rate constant at } 20{ }^{\circ} \mathrm{C} \text { for emigration of adult alate }[\mathrm{Eq} \\
(61)]\end{array}$ & $1 \mathrm{~d}^{-1}$ \\
\hline$k_{\text {aph,Nmort,max }}$ & $\begin{array}{l}\text { Maximum rate constant for nutrition-dependent aphid } \\
\text { mortality }[\mathrm{Eq}(10)]\end{array}$ & $0.1 \mathrm{~d}^{-1}$ \\
\hline$k_{\text {aph,Tmort }, 0}, k_{\text {aph,Tmort,opt }}$ & $\begin{array}{l}\text { Rate constants for temperature-dependent mortality [Eq } \\
(9)]\end{array}$ & $0.04,0 \mathrm{~d}^{-1}$ \\
\hline$k_{\text {le } \rightarrow \text { prune }}$ & Foliage pruning constant [Eq (14)] & $0 \mathrm{~d}^{-1}$ \\
\hline $\begin{array}{l}M_{\mathrm{Cala} \jmath}, \jmath=1 \ldots 4 ; M_{\mathrm{Calaa}} \\
M_{\mathrm{Capt} \jmath}, \jmath=1 \ldots 4 ; M_{\mathrm{Capta}}\end{array}$ & $\begin{array}{l}\text { Carbon mass in alate, apterous instar and adult aphids } \\
{[\mathrm{Eq}(7)]}\end{array}$ & $\begin{array}{l}1,2,3,4 ; 5 ; 1,2,3 \\
4 ; 5, \times 10^{-6} \mathrm{~kg} \mathrm{C} \\
\text { aphid }^{-1}\end{array}$ \\
\hline $\begin{array}{l}M_{\mathrm{Nala} \jmath}, \jmath=1 \ldots 4 ; M_{\mathrm{Nalaa}} \\
M_{\mathrm{Napt} \jmath}, \jmath=1 \ldots 4 ; M_{\mathrm{Napta}}\end{array}$ & $\begin{array}{l}\text { Nitrogen mass in alate, apterous instar and adult aphids } \\
{[\mathrm{Eq}(7)]}\end{array}$ & $\begin{array}{l}1,2,3,4 ; 5 ; 1,2,3 \\
4,5, \times 10^{-6} \mathrm{~kg} \mathrm{C} \\
\text { aphid }^{-1}\end{array}$ \\
\hline$m_{\mathrm{CS}}, m_{\mathrm{NS}}$ & $\begin{array}{l}\text { Multipliers converting mass concentrations into volume } \\
\text { concentrations }[\mathrm{Eq}(2)]\end{array}$ & $\begin{array}{l}5000,1000 \mathrm{~kg} \\
\text { structural DM m}\end{array}$ \\
\hline$q_{1}, q_{2}$ & Exponents in general temperature function $[\mathrm{Eq}(17)]$ & 2,1 \\
\hline$q_{\text {aph,Nmort }}$ & $\begin{array}{l}\text { Sigmoidicity constant for nutrition-dependent }(\mathrm{N}) \text { aphid } \\
\text { mortality }[\mathrm{Eq}(10)]\end{array}$ & 2 \\
\hline 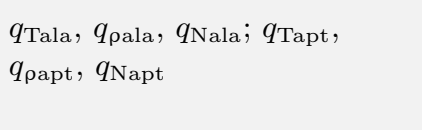 & $\begin{array}{l}\text { Sigmoidicity constants for effects of temperature, aphid } \\
\text { density and nutrition on the alate fraction in alate, } \\
\text { apterous offspring }[\mathrm{Eqs}(70)-(72),(25)-(27)]\end{array}$ & $2,2,2,2,2,2$ \\
\hline$r_{\mathrm{CN}, \mathrm{cell}}, r_{\mathrm{CN}, \mathrm{lig}}$ & Cellulose, lignin, C:N ratios [Eq (128)] & $\begin{array}{l}150,100 \mathrm{~kg} \mathrm{C}(\mathrm{kg} \\
\mathrm{N})^{-1}\end{array}$ \\
\hline$T_{\text {aph,mort }, 0}, T_{\text {aph,mort,opt }}$ & Temperatures for aphid mortality rate constants (9) & $0,15{ }^{\circ} \mathrm{C}$ \\
\hline$T_{0}, T_{\text {ref }}, T_{0}^{\prime}$ & $\begin{array}{l}\text { Temperatures defining the standard temperature } \\
\text { function }[\mathrm{Eq}(17)]\end{array}$ & $0,20,45^{\circ} \mathrm{C}$ \\
\hline $\begin{array}{l}T_{0 \text { aph,dev }}, T_{\text {Oaph,dev }}^{\prime} \\
T_{0 \text { aph,fec }}, T_{\text {Oaph,fec }}^{\prime}\end{array}$ & $\begin{array}{l}\text { Temperatures modifying the standard temperature } \\
\text { function }[\mathrm{Eq}(17)] \text {, for development }[\mathrm{Eq}(35)] ; \text { fecundity } \\
{[\mathrm{Eq}(18)]}\end{array}$ & $\begin{array}{l}0 \text { (unchanged), } 30 ; 3, \\
30{ }^{\circ} \mathrm{C}\end{array}$ \\
\hline$v_{\text {alaa, } \max 20}, v_{\text {apta, } \max 20}$ & $\begin{array}{l}\text { Maximum volume intake rate of phloem sap by alate, } \\
\left.\text { apterous adults at } 20{ }^{\circ} \mathrm{C} \text { [Eqs }(65),(19)\right]\end{array}$ & $\begin{array}{l}0.2 \times 10^{-6} \mathrm{~m}^{3} \\
\text { aphid }^{-1} \mathrm{~d}^{-1}\end{array}$ \\
\hline \multicolumn{3}{|c|}{ Other aphid sub-model variables } \\
\hline Symbol & Definition & Values and Units \\
\hline$a_{\mathrm{lai}}, a_{\mathrm{pti}}, a_{\mathrm{la}}, a_{\mathrm{pt}}, a_{\mathrm{ph}}$ & $\begin{array}{l}\text { Alate, apterous instar totals, alate, apterous totals, total } \\
\text { aphids }[\mathrm{Eq}(4)]\end{array}$ & $\begin{array}{l}\text { Aphid number } \\
\text { stem }^{-1}\end{array}$ \\
\hline$A_{\text {leaf,aph }}$ & Leaf area colonized by aphids [Eq (5)] & $\mathrm{m}^{2}$ leaf stem ${ }^{-1}$ \\
\hline $\begin{array}{l}C_{\text {ala }}, C_{\text {aph }}, C_{\text {apt }}, N_{\text {ala }}, N_{\text {aph }} \\
N_{\text {apt }}\end{array}$ & $\begin{array}{l}\text { Aphid } \mathrm{C} \text { and } \mathrm{N} \text { per stem for alate, total and apterous } \\
\text { aphids }[\mathrm{Eq}(6)]\end{array}$ & $\begin{array}{l}\text { kg aphid C, N } \\
\text { stem }^{-1}\end{array}$ \\
\hline $\mathrm{d} a_{\mathrm{ph}} / \mathrm{d} t$ & $\begin{array}{l}\text { Rate of change of total aphid number [Eq (101), cf. Eq } \\
(102)]\end{array}$ & Aphids stem ${ }^{-1} \mathrm{~d}^{-1}$ \\
\hline $\begin{array}{l}\mathrm{d} C_{\text {aph }} / \mathrm{d} t, \mathrm{~d} C_{\text {aph }, \mathrm{m} 2} / \mathrm{d} t \\
\mathrm{~d} N_{\text {aph }} / \mathrm{d} t, \\
\mathrm{~d} N_{a p h, m 2} / \mathrm{d} t\end{array}$ & $\begin{array}{l}\text { Rate of change of total aphid C, N [Eqs (113), (123); cf. } \\
\text { Eqs }(114),(124)]\end{array}$ & $\begin{array}{l}\mathrm{kg} \text { aphid } \mathrm{C}, \mathrm{N} \\
\text { stem }^{-1}, \mathrm{~kg} \text { aphid } \mathrm{C} \\
\mathrm{N} \mathrm{m}^{-2}\end{array}$ \\
\hline \multicolumn{3}{|r|}{ continued on next page } \\
\hline
\end{tabular}




\begin{tabular}{|c|c|c|}
\hline Symbol & Definition & Values and Units \\
\hline$f(T)$ & Standard biological temperature function $[\mathrm{Eq}(17)]$ & \\
\hline $\begin{array}{l}f_{\text {alaa } \rightarrow \text { ala } 1}, f_{\text {alaa } \rightarrow \text { apt } 1} \\
f_{\text {apta } \rightarrow \text { ala } 1}, f_{\text {apta } \rightarrow \text { apt } 1}\end{array}$ & $\begin{array}{l}\text { Fractions of alate, apterous offspring which are alate or } \\
\text { apterous }[\text { Eqs }(73),(28)\end{array}$ & \\
\hline$f_{\text {fecalaa }}, f_{\text {fecapta }}$ & $\begin{array}{l}\text { Fractional fecundity of alate, apterous adults, Eqs (74), } \\
(29)]\end{array}$ & $\mathrm{d}^{-1}$ \\
\hline 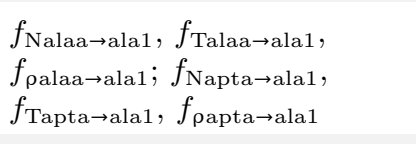 & $\begin{array}{l}\text { Fractions of alate, apterous offspring which are alate, as } \\
\text { affected by nutrition }(\mathrm{N}) \text {, temperature }(\mathrm{T}) \text { and aphid } \\
\text { density }(\rho)[\text { Eqs }(70)-(72) ;(25)-(27)]\end{array}$ & \\
\hline$f_{\text {Oalaa } \rightarrow \text { emi }}, f_{\text {Oalaa } \rightarrow \text { mort }}$ & $\begin{array}{l}\text { Fractional output fluxes of alate adults to emigration } \\
\text { and mortality }[\mathrm{Eq}(99)]\end{array}$ & \\
\hline$f_{\mathrm{TNaph}, \mathrm{dev}}$ & $\begin{array}{l}\text { Combined effects of temperature and } \mathrm{N} \text { on development } \\
{[\mathrm{Eq}(37)]}\end{array}$ & \\
\hline$f(T), f\left(T=T_{\text {air }}\right)$ & $\begin{array}{l}\text { Temperature function (17), used to modify emigration } \\
\text { [Eq (61)] }\end{array}$ & \\
\hline$I_{\mathrm{ala} \jmath}, I_{\mathrm{apt} \jmath}, \jmath=1 \ldots 4$ & Inputs to alate, apterous instar pools [Eqs $(81),(41)]$ & aphids stem ${ }^{-1} \mathrm{~d}^{-1}$ \\
\hline$I_{\text {alaa }}, I_{\text {apta }}$ & Total inputs to alate, apterous adult pools [Eqs $(57),(8)]$ & aphids stem ${ }^{-1} \mathrm{~d}^{-1}$ \\
\hline$I_{\text {ala } 4 \rightarrow \text { alaa }}, I_{\text {imm } \rightarrow \text { alaa }}$ & $\begin{array}{l}\text { Inputs to alate adult pools from development [Eq (83)], } \\
\text { immigration }[\mathrm{Eq}(56) \text { but see Eq (64)] }\end{array}$ & aphids stem ${ }^{-1} \mathrm{~d}^{-1}$ \\
\hline $\begin{array}{l}I_{\text {alaa } \rightarrow \text { apt } 1}, I_{\text {alaa } \rightarrow \text { ala } 1} \\
I_{\text {apta } \rightarrow \text { apt } 1}, I_{\text {apta } \rightarrow \text { ala } 1}\end{array}$ & $\begin{array}{l}\text { Inputs to } 1^{\text {th }} \text { instar apterous and alate pools from alate, } \\
\text { apterous progeny }[\text { Eqs }(74),(30)]\end{array}$ & aphids stem ${ }^{-1} \mathrm{~d}^{-1}$ \\
\hline $\begin{array}{l}I_{\text {Cala } 4 \rightarrow \mathrm{a}}, I_{\text {Nala4 } \rightarrow \mathrm{a}} ; I_{\mathrm{Capt} 4 \rightarrow \mathrm{a}} \\
I_{\text {Napt } 4 \rightarrow \mathrm{a}}\end{array}$ & $\begin{array}{l}\text { Inputs of } \mathrm{C}, \mathrm{N} \text { from } 4^{\text {th }} \text { instar into alate and apterous } \\
\text { adult aphids }[\text { Eqs }(58),(8)]\end{array}$ & aphids stem ${ }^{-1} \mathrm{~d}^{-1}$ \\
\hline $\begin{array}{l}I_{\mathrm{Caph}}, I_{\mathrm{Caph}, \mathrm{m} 2}, I_{\mathrm{Naph}} \\
I_{\mathrm{Naph}, \mathrm{m} 2}\end{array}$ & Total C, N inputs to aphids [Eqs (105), (117)] & $\begin{array}{l}\text { kg aphid } \mathrm{C}, \mathrm{N} \\
\text { stem } \\
\mathrm{C}, \mathrm{N} \mathrm{m}^{-2} \mathrm{~d}^{-1}, \mathrm{~kg} \text { aphid }\end{array}$ \\
\hline$I_{\mathrm{Caph} \rightarrow \text { surf-li }}, I_{\mathrm{Naph} \rightarrow \text { surf-li }}$ & $\begin{array}{l}\text { Aphid } \mathrm{C}, \mathrm{N} \text { inputs to the surface litter cellulose }+ \text { lignin } \\
\text { pools }[\mathrm{Eq}(126)]\end{array}$ & $\mathrm{kg} \mathrm{C}, \mathrm{N} \mathrm{m}^{-2} \mathrm{~d}^{-1}$ \\
\hline $\begin{array}{l}I_{\text {Caph } \rightarrow \text { surf-li,cel }} \\
I_{\text {Caph } \rightarrow \text { surf-li,lig }} \\
I_{\text {Caph } \rightarrow \text { surf-li,met }}\end{array}$ & $\begin{array}{l}\text { C inputs to surface litter cellulose, lignin, metabolic } \\
\text { pools }[\text { Eqs }(127),(125)]\end{array}$ & $\mathrm{kg} \mathrm{C} \mathrm{m}{ }^{-2} \mathrm{~d}^{-1}$ \\
\hline $\begin{array}{l}I_{\mathrm{Cimm} \rightarrow \text { alaa }}, I_{\mathrm{Cimm} \rightarrow \text { alaa }, \mathrm{m} 2} \\
I_{\mathrm{Nimm} \rightarrow \text { alaa }}, I_{\mathrm{Nimm} \rightarrow \text { alaa }, \mathrm{m} 2}\end{array}$ & $\begin{array}{l}\text { Input of C, } \mathrm{N} \text { from immigrating alate adults [Eqs (104), } \\
(116)]\end{array}$ & $\begin{array}{l}\operatorname{kg~C}, \mathrm{N} \mathrm{stem}^{-1} \mathrm{~d}^{-1} \\
\operatorname{kg~C}, \mathrm{N} \mathrm{m}^{-2} \mathrm{~d}^{-1}\end{array}$ \\
\hline $\begin{array}{l}I_{\text {Cphloem } \rightarrow \text { alaa, aphid }} \\
I_{\text {Cphloem } \rightarrow \text { apta,aphid }} \\
I_{\text {Nphloem } \rightarrow \text { alaa, aphid }} \\
I_{\text {Nphloem } \rightarrow \text { apta,aphid }}\end{array}$ & $\begin{array}{l}\mathrm{C}, \mathrm{N} \text { intake rates per alate, apterous adult aphid [Eqs } \\
(69),(24),(67),(22)]\end{array}$ & $\operatorname{kg} \mathrm{C}, \mathrm{N}$ aphid ${ }^{-1} \mathrm{~d}^{-1}$ \\
\hline $\begin{array}{l}I_{\mathrm{Cphloem} \rightarrow \text { ala } \jmath}, I_{\mathrm{Cphloem} \rightarrow \text { apt } \jmath} \\
I_{\mathrm{Nphloem} \rightarrow \text { ala } \jmath}, I_{\mathrm{Nphloem} \rightarrow \text { apt } \jmath} \\
\jmath=1, \ldots, 4\end{array}$ & $\begin{array}{l}\text { C inputs required for development by } 4 \text { alate instars } \\
(\jmath=1, \ldots, 4) \text {, all } 4 \text { alate instars summed (alai) [Eqs }(92) \text {, } \\
(90)], 4 \text { apterous instars }(\jmath=1, \ldots, 4) \text { all } 4 \text { apterous } \\
\text { instars summed (apti) [Eqs }(52),(50)]\end{array}$ & $\mathrm{kg} \mathrm{C}$ stem $^{-1} \mathrm{~d}^{-1}$ \\
\hline $\begin{array}{l}I_{\text {Cphloem } \rightarrow \text { alai }}, I_{\text {Cphloem } \rightarrow \text { apti }} \\
I_{\text {Nphloem } \rightarrow \text { alai }}, I_{\text {Nphloem } \rightarrow \text { apti }}\end{array}$ & $\begin{array}{l}\text { Total C, N inputs from phloem to all } 4 \text { alate, apterous } \\
\text { instars [Eqs }(90),(50),(89),(49)]\end{array}$ & $\mathrm{kg} \mathrm{C}, \mathrm{N}$ stem $^{-1} \mathrm{~d}^{-1}$ \\
\hline $\begin{array}{l}I_{\mathrm{Cphloem} \rightarrow \text { ala } j} ; I_{\mathrm{Cphloem} \rightarrow \text { alai }} \\
I_{\mathrm{Cphloem} \rightarrow \text { apt } \jmath}, I_{\mathrm{Cphloem} \rightarrow \text { apti }} \\
\jmath=1, \ldots, 4\end{array}$ & $\begin{array}{l}\mathrm{C} \text { inputs required for development by alate, apterous } \\
\text { instars, all } 4 \text { instars }[\operatorname{Eqs}(92),(90),(52),(50)]\end{array}$ & $\mathrm{kg} \mathrm{C}$ stem $^{-1} \mathrm{~d}^{-1}$ \\
\hline
\end{tabular}




\begin{tabular}{|c|c|c|}
\hline Symbol & Definition & Values and Units \\
\hline $\begin{array}{l}I_{\text {Cphloem } \rightarrow \text { aph }}, \\
I_{\text {Cphloem } \rightarrow \text { aph }, m 2}, \\
I_{\text {Nphloem } \rightarrow \text { aph }}, \\
I_{\text {Nphloem } \rightarrow \text { aph }, m 2}\end{array}$ & $\begin{array}{l}\text { Total C, N input to aphids from phloem [Eqs (103), } \\
(115)]\end{array}$ & $\begin{array}{l}\operatorname{kg~C}, \mathrm{N} \mathrm{stem}^{-1} \mathrm{~d}^{-1} \\
\mathrm{~kg} \mathrm{C}, \mathrm{N} \mathrm{m}^{-2} \mathrm{~d}^{-1}\end{array}$ \\
\hline$I_{\text {Npalaa,max }}, I_{\text {Npapta,max }}$ & $\begin{array}{l}\text { Maximum processing } \mathrm{N} \text { intake rate per alate, apterous } \\
\text { adult aphid }[\text { Eqs }(66),(21)]\end{array}$ & $\operatorname{kg~N}$ aphid $^{-1} \mathrm{~d}^{-1}$ \\
\hline $\begin{array}{l}I_{\text {Nphloem,valaa,max }} \\
I_{\text {Nphloem,vapta,max }}\end{array}$ & $\begin{array}{l}\text { Maximum phloem volume-limited } \mathrm{N} \text { intake rate per } \\
\text { alate, apterous adult aphid [Eqs }(65),(20)]\end{array}$ & $\operatorname{kg~N}$ aphid $^{-1} \mathrm{~d}^{-1}$ \\
\hline $\begin{array}{l}I_{\text {Cphloem } \rightarrow \text { alaa }}, I_{\text {Cphloem } \rightarrow \text { apta }} \\
I_{\text {Nphloem } \rightarrow \text { alaa }}, I_{\text {Nphloem } \rightarrow \text { apta }}\end{array}$ & $\begin{array}{l}\mathrm{C}, \mathrm{N} \text { inputs from phloem to alate, apterous adults [Eqs } \\
(69),(24)]\end{array}$ & $\operatorname{kg} \mathrm{C}, \mathrm{N}$ aphid ${ }^{-1} \mathrm{~d}^{-1}$ \\
\hline $\begin{array}{l}I_{\mathrm{Nphloem} \rightarrow \text { ala } \jmath}, I_{\mathrm{Nphloem} \rightarrow \text { apt } \jmath} \\
\jmath=1, \ldots, 4\end{array}$ & $\begin{array}{l}\mathrm{N} \text { inputs from phloem to alate, apterous instars [Eqs } \\
(88),(48)]\end{array}$ & $\operatorname{kg~N}$ aphid $^{-1} \mathrm{~d}^{-1}$ \\
\hline $\begin{array}{l}k_{\text {ala } \jmath \rightarrow \jmath+1}, k_{\text {apt } \jmath \rightarrow \jmath+1} \\
\jmath=1, \ldots, 3, k_{\text {ala } 4 \rightarrow \mathrm{a}}, k_{\text {apt } 4 \rightarrow \mathrm{a}}\end{array}$ & Developmental rate parameters [Eqs (79), (38)] & $\mathrm{d}^{-1}$ \\
\hline$k_{\text {alaa } \rightarrow \text { emi }}$ & Rate parameter for emigration of adult alates $[\mathrm{Eq}(61)]$ & $\mathrm{d}^{-1}$ \\
\hline$k_{\text {aph,mort }}$ & Mortality rate $[\mathrm{Eq}(11)]$ & $\mathrm{d}^{-1}$ \\
\hline$k_{\text {aph,Nmort }}$ & Nutrition-dependent mortality rate [Eq (10)] & $\mathrm{d}^{-1}$ \\
\hline$k_{\text {aph,Tmort }}$ & Temperature-dependent mortality rate & $\mathrm{d}^{-1}$ \\
\hline $\begin{array}{l}O_{\text {ala }\lrcorner \rightarrow \jmath+1}, O_{\text {apt } \jmath \rightarrow \jmath+1}, \\
\jmath=1, \ldots, 3, O_{\text {ala } 4 \rightarrow \mathrm{a}}, \\
O_{\text {apt } 4 \rightarrow \mathrm{a}}\end{array}$ & $\begin{array}{l}\text { Developmental outputs from alate, apterous instar pools } \\
{[\text { Eqs }(82),(42)]}\end{array}$ & aphids stem ${ }^{-1} \mathrm{~d}^{-1}$ \\
\hline $\begin{array}{l}O_{\text {ala } \jmath \rightarrow \text { mort }}, O_{\text {apt } \jmath \rightarrow \text { mort }} \\
O_{\text {ala } \jmath \rightarrow \text { prune }}, O_{\text {apt } \jmath \rightarrow \text { prune }} \\
\jmath=1, \ldots, 4\end{array}$ & $\begin{array}{l}\text { Outputs from alate, apterous instar pools to mortality } \\
\text { [Eqs }(84),(44)] \text {, pruning }[\text { Eqs }(85),(45)]\end{array}$ & aphids stem ${ }^{-1} \mathrm{~d}^{-1}$ \\
\hline $\begin{array}{l}O_{\text {ala } \rightarrow \text { mort }}, O_{\text {ala } \rightarrow \text { prune }} \\
O_{\text {apt } \rightarrow \text { mort }}, O_{\text {apt } \rightarrow \text { prune }}\end{array}$ & $\begin{array}{l}\text { Total outputs from alate, apterous aphids to mortality } \\
{[\text { Eqs }(84),(44)] \text { and pruning }[\text { Eqs }(85),(45)]}\end{array}$ & aphids stem ${ }^{-1} \mathrm{~d}^{-1}$ \\
\hline$O_{\mathrm{ala} \jmath}, O_{\mathrm{apt} \jmath}, \jmath=1, \ldots, 4$ & $\begin{array}{l}\text { Total outputs from alate; apterous instar pools [Eqs (86), } \\
(46)]\end{array}$ & aphids stem ${ }^{-1} \mathrm{~d}^{-1}$ \\
\hline$O_{\text {alaa }}, O_{\text {apta }}$ & Total output of alate, apterous adults [Eqs (63), (15)] & aphids stem ${ }^{-1} \mathrm{~d}^{-1}$ \\
\hline $\begin{array}{l}O_{\text {alaa } \rightarrow \text { ala } 1}, O_{\text {alaa } \rightarrow \text { apt } 1} \\
O_{\text {apta } \rightarrow \text { ala } 1}, O_{\text {apta } \rightarrow \text { apt } 1}\end{array}$ & $\begin{array}{l}\text { Output of alate and apterous } 1^{\text {st }} \text { instar nymphs from } \\
\text { alate, apterous adult progeny [Eqs }(74),(29),(30)]\end{array}$ & aphids stem ${ }^{-1} \mathrm{~d}^{-1}$ \\
\hline$O_{\text {alaa } \rightarrow \text { emi }}$ & Output of alate adults to emigration [Eq (62)] & aphids stem ${ }^{-1} \mathrm{~d}^{-1}$ \\
\hline $\begin{array}{l}O_{\text {alaa } \rightarrow \text { mort }}, O_{\text {alaa } \rightarrow \text { prune }} \\
O_{\text {apta } \rightarrow \text { mort }}, O_{\text {apta } \rightarrow \text { prune }}\end{array}$ & $\begin{array}{l}\text { Outputs of alate, apterous adults to mortality [Eqs (59), } \\
(12)] \text {, pruning }[\text { Eqs }(60),(14)]\end{array}$ & aphids stem ${ }^{-1} \mathrm{~d}^{-1}$ \\
\hline $\begin{array}{l}O_{\text {aph } \rightarrow \text { fec }}, O_{\text {aph } \rightarrow \text { mort }} \\
O_{\text {aph } \rightarrow \text { prune }}\end{array}$ & $\begin{array}{l}\text { Total aphid outputs from fecundity, to mortality and } \\
\text { pruning }[\text { Eqs }(100),(96),(85)]\end{array}$ & aphids stem ${ }^{-1} \mathrm{~d}^{-1}$ \\
\hline $\begin{array}{l}O_{\text {Calaa } \rightarrow \text { ala } 1}, O_{\text {Calaa } \rightarrow \text { apt } 1}, \\
O_{\text {Nalaa } \rightarrow \text { ala } 1}, O_{\text {Nalaa } \rightarrow \text { apt } 1}, \\
O_{\text {Nalaa } \rightarrow \text { axx } 1}, O_{\text {Calaa } \rightarrow \text { hon }}\end{array}$ & $\begin{array}{l}\mathrm{C}, \mathrm{N} \text { fluxes from alate adults to offspring [Eqs }(77),(75)] \\
\text { and } \mathrm{C} \text { flux to honeydew [Eq }(78)]\end{array}$ & $\mathrm{kg} \mathrm{C}, \mathrm{N}$ stem $^{-1} \mathrm{~d}^{-1}$ \\
\hline $\begin{array}{l}O_{\text {Calaa } \rightarrow \text { emi }}, O_{\text {Nalaa } \rightarrow \text { emi }} \\
O_{\text {Calaa } \rightarrow \text { emi }, \mathrm{m} 2} \\
O_{\text {Nalaa } \rightarrow \text { emi }, \mathrm{m} 2}\end{array}$ & $\begin{array}{l}\text { C, N outputs with emigrating alates [per stem Eq (62)] } \\
{[\text { per unit ground area Eqs }(109),(119)]}\end{array}$ & $\begin{array}{l}\mathrm{kg} \mathrm{C}, \mathrm{N} \text { stem }^{-1} \mathrm{~d}^{-1} \\
\mathrm{~kg} \mathrm{C}, \mathrm{N} \mathrm{m}^{-2} \mathrm{~d}^{-1}\end{array}$ \\
\hline $\begin{array}{l}O_{\text {Calaa } \rightarrow \text { mort }}, O_{\text {Nalaa } \rightarrow \text { mort }} \\
O_{\text {Capta } \rightarrow \text { mort }}, O_{\text {Napta } \rightarrow \text { mort }}\end{array}$ & $\begin{array}{l}\text { C, N outputs of alate, apterous adults to mortality [Eqs } \\
(59),(13)]\end{array}$ & $\begin{array}{l}\text { kg aphid C, N } \\
\text { stem }^{-1} \mathrm{~d}^{-1}\end{array}$ \\
\hline
\end{tabular}




\begin{tabular}{|c|c|c|}
\hline Symbol & Definition & Values and Units \\
\hline $\begin{array}{l}O_{\text {Calaa } \rightarrow \text { prune }}, O_{\text {Nalaa } \rightarrow \text { prune }} \\
O_{\text {Capta } \rightarrow \text { prune }}, O_{\text {Napta } \rightarrow \text { prune }}\end{array}$ & $\begin{array}{l}\mathrm{C}, \mathrm{N} \text { fluxes of alate, apterous adults to pruning [Eqs } \\
(60),(14)]\end{array}$ & $\begin{array}{l}\text { kg aphid C, N } \\
\text { stem }^{-1} \mathrm{~d}^{-1}\end{array}$ \\
\hline$O_{\text {Calai } \rightarrow \text { hon }}, O_{\text {Capti } \rightarrow \text { hon }}$ & $\begin{array}{l}\text { C outputs from alate, apterous instars to honeydew [Eqs } \\
(93),(53)]\end{array}$ & $\mathrm{kg} \mathrm{C}$ stem $^{-1} \mathrm{~d}^{-1}$ \\
\hline $\begin{array}{l}O_{\mathrm{Caph}}, O_{\mathrm{Caph}, \mathrm{m} 2}, O_{\mathrm{Naph}} \\
O_{\mathrm{Naph}, \mathrm{m} 2}\end{array}$ & Total aphid C, N outputs [Eqs (112), (122)] & $\begin{array}{l}\operatorname{kg~C}, \mathrm{N} \mathrm{stem}^{-1} \mathrm{~d}^{-1} \\
\operatorname{kg~C}, \mathrm{N} \mathrm{m}^{-2} \mathrm{~d}^{-1}\end{array}$ \\
\hline$O_{\mathrm{Caph} \rightarrow \mathrm{CO} 2}, O_{\mathrm{Caph} \rightarrow \mathrm{CO} 2, \mathrm{~m} 2}$ & Total aphid respiration, [Eq (106)] & $\begin{array}{l}\mathrm{kg} \mathrm{C} \text { stem }^{-1} \mathrm{~d}^{-1}, \mathrm{~kg} \\
\mathrm{C} \mathrm{\textrm {m } ^ { - 2 }} \mathrm{d}^{-1}\end{array}$ \\
\hline$O_{\mathrm{Caph} \rightarrow \mathrm{hon}}, O_{\mathrm{Caph} \rightarrow \mathrm{hon}, \mathrm{m} 2}$ & Total C outputs to honeydew [Eq (107)] & $\begin{array}{l}\mathrm{kg} \mathrm{C} \text { stem }^{-1} \mathrm{~d}^{-1}, \mathrm{~kg} \\
\mathrm{C} \mathrm{\textrm {m } ^ { - 2 }} \mathrm{d}^{-1}\end{array}$ \\
\hline $\begin{array}{l}O_{\mathrm{Caph} \rightarrow \text { mort }}, O_{\mathrm{Caph} \rightarrow \mathrm{mort}, \mathrm{m} 2} \\
O_{\mathrm{Naph} \rightarrow \mathrm{mort}}, O_{\mathrm{Naph} \rightarrow \mathrm{mort}, \mathrm{m} 2}\end{array}$ & Total C, N outputs to mortality [Eqs (108), (118)] & $\begin{array}{l}\operatorname{kg~C}, \mathrm{N} \mathrm{stem}^{-1} \mathrm{~d}^{-1} \\
\mathrm{~kg} \mathrm{C}, \mathrm{N} \mathrm{m}^{-2} \mathrm{~d}^{-1}\end{array}$ \\
\hline $\begin{array}{l}O_{\text {Caph } \rightarrow \text { prune }} \\
O_{\text {Caph } \rightarrow \text { prune,m2 }} \\
O_{\text {Naph } \rightarrow \text { prune }} \\
O_{\text {Naph } \rightarrow \text { prune,m2 }}\end{array}$ & Total C, N outputs to pruning [Eqs (110), (120)] & $\begin{array}{l}\mathrm{kg} \mathrm{C}, \mathrm{N} \mathrm{stem}^{-1} \mathrm{~d}^{-1} \\
\mathrm{~kg} \mathrm{C}, \mathrm{N} \mathrm{m}^{-2} \mathrm{~d}^{-1}\end{array}$ \\
\hline$O_{\mathrm{Caph} \rightarrow \mathrm{th}, \mathrm{m} 2}, O_{\mathrm{Naph} \rightarrow \mathrm{th}, \mathrm{m} 2}$ & Total C, N outputs from thinning [Eqs (111), (121)] & $\operatorname{kg~C}, \mathrm{N} \mathrm{m}^{-2} \mathrm{~d}^{-1}$ \\
\hline $\begin{array}{l}O_{\text {Capta } \rightarrow \text { ala } 1}, O_{\text {Capta } \rightarrow \text { apt } 1}, \\
O_{\text {Capta } \rightarrow \text { axx } 1}, O_{\text {Capta } \rightarrow \text { hon }} \\
O_{\text {Napta } \rightarrow \text { ala } 1}, O_{\text {Napta } \rightarrow \text { apt } 1} \\
O_{\text {Napta } \rightarrow \text { axx } 1}\end{array}$ & $\begin{array}{l}\mathrm{C}, \mathrm{N} \text { fluxes from apterous adults to offspring [Eqs (33), } \\
(31)] \text { and }(\mathrm{C}) \text { to honeydew [Eq (34)] }\end{array}$ & $\mathrm{kg} \mathrm{C}, \mathrm{N} \mathrm{stem}^{-1} \mathrm{~d}^{-1}$ \\
\hline$O_{\mathrm{Cphloem} \rightarrow \text { alai }}, O_{\mathrm{Cphloem} \rightarrow \text { apti }}$ & $\begin{array}{l}\text { C outputs from phloem to support instar development, } \\
\text { [Eqs }(92),(52)]\end{array}$ & $\mathrm{kg} \mathrm{C}$ stem $^{-1} \mathrm{~d}^{-1}$ \\
\hline $\begin{array}{l}O_{\text {Calai } \rightarrow \text { mort }}, O_{\text {Nalai } \rightarrow \text { mort }}, \\
O_{\text {Calai } \rightarrow \text { prune }}, O_{\text {Nalai } \rightarrow \text { prune }} ; \\
O_{\text {Capti } \rightarrow \text { mort }}, O_{\text {Napti } \rightarrow \text { mort }}, \\
O_{\text {Capti } \rightarrow \text { prune }}, O_{\text {Napti } \rightarrow \text { prune }}\end{array}$ & $\begin{array}{l}\text { C, N outputs from alates, apterous instars to mortality, } \\
\text { pruning }[\text { Eqs }(94),(95),(54),(55)]\end{array}$ & $\mathrm{kg} \mathrm{C}, \mathrm{N} \mathrm{stem}^{-1} \mathrm{~d}^{-1}$ \\
\hline$R_{\text {alaa }}, R_{\text {alai }}, R_{\text {apta }}, R_{\text {apti }}$ & $\begin{array}{l}\text { Respiration from alate, apterous adults, all instars [Eqs } \\
(76),(91),(32),(51)]\end{array}$ & $\mathrm{kg} \mathrm{C}$ stem $^{-1} \mathrm{~d}^{-1}$ \\
\hline$s_{\text {urvival }}$ & $\begin{array}{l}\text { Probability of survival of a } 1^{\text {st }} \text { instar apterous aphid [Eq } \\
(40)]\end{array}$ & \\
\hline$v_{\text {phloem } \rightarrow \text { alaa }}, v_{\text {phloem } \rightarrow \text { apta }}$ & $\begin{array}{l}\text { Phloem volume sap intake rate by alate, apterous adults } \\
\text { [Eqs }(68),(23)]\end{array}$ & $\mathrm{m}^{3}$ aphid $^{-1} \mathrm{~d}^{-1}$ \\
\hline$v_{\text {alaa, } \max }, v_{\text {apta,max }}$ & $\begin{array}{l}\text { Maximum volume intake rate of phloem sap by alate, } \\
\text { apterous adults [Eqs }(65),(19)]\end{array}$ & $\mathrm{m}^{3}$ aphid $^{-1} \mathrm{~d}^{-1}$ \\
\hline$\rho_{\text {ala }}, \rho_{\text {aph }}, \rho_{\text {apt }}$ & Aphid densities of alates, all aphids, apterous [Eq (5)] & Aphids $\left(\mathrm{m}^{2} \text { leaf }\right)^{-1}$ \\
\hline & \multicolumn{2}{|l|}{ Forest sub-model variables and parameters } \\
\hline Symbol & Definition & Values and Units \\
\hline$A_{\text {leaf }}$ & Leaf area per stem $[\mathrm{Eq}(1)]$ & $\mathrm{m}^{2}$ stem $^{-1}$ \\
\hline$A_{\text {leaf,aph }}$ & Leaf area colonized by aphids [Eq (5)] & $\mathrm{m}^{2}$ stem $^{-1}$ \\
\hline$C_{\mathrm{le}}, N_{\mathrm{le}}$ & $\begin{array}{l}\text { Substrate C, N concentrations in foliage (leaf) (le) [Eq } \\
(2)]\end{array}$ & $\begin{array}{l}\mathrm{kg} \text { substrate } \mathrm{C}, \mathrm{N} \\
(\mathrm{kg} \text { structural } \mathrm{DM})^{-1}\end{array}$ \\
\hline \multirow[t]{2}{*}{$C_{\text {phloem }}, N_{\text {phloem }}$} & $\mathrm{C}, \mathrm{N}$ substrate concentrations in phloem sap [Eq (2)] & $\begin{array}{l}\mathrm{kg} \text { substrate } \mathrm{C}, \mathrm{N} \\
\left(\mathrm{m}^{3} \text { phloem sap }\right)^{-1}\end{array}$ \\
\hline & \multicolumn{2}{|r|}{ continued on next page } \\
\hline
\end{tabular}


bioRxiv preprint doi: https://doi.org/10.1101/2021.05.26.445772; this version posted May 26, 2021. The copyright holder for this preprint (which

was not certified by peer review) is the author/funder, who has granted bioRxiv a license to display the preprint in perpetuity. It is made available under aCC-BY 4.0 International license.

\begin{tabular}{|c|c|c|}
\hline Symbol & Definition & Values and Units \\
\hline$C_{\text {sys }}$ & Total C sequestered by system [Fig 7] & $\operatorname{kg~C~}\left(\mathrm{m}^{2} \text { ground }\right)^{-1}$ \\
\hline$k_{\text {le } \rightarrow \text { prune }}$ & Foliage $(l e)$ pruning rate $[\mathrm{Eq}(14)]$ & $0 \mathrm{~d}^{-1}$ \\
\hline$L_{\mathrm{AI}}$ & Leaf area index $[\mathrm{Eq}(1)]$ & $\begin{array}{l}\left(\mathrm{m}^{2} \text { leaf }\right)\left(\mathrm{m}^{2}\right. \\
\text { ground })^{-1}\end{array}$ \\
\hline$n_{\text {stems }}$ & $\begin{array}{l}\text { Number of stems per unit ground area [efm state } \\
\text { variable, Eq (1)] }\end{array}$ & $\begin{array}{l}\text { Number of stems }\left(\mathrm{m}^{2}\right. \\
\text { ground })^{-1}\end{array}$ \\
\hline$O_{\text {nstems,th }}$ & $\begin{array}{l}\text { Output of stems due to management thinning [Eq (1)]. } \\
\text { Section } 4.2\end{array}$ & $\begin{array}{l}\text { Number of stems } \mathrm{m}^{-2} \\
\mathrm{~d}^{-1}\end{array}$ \\
\hline$r_{\mathrm{CNphloem}}$ & Phloem C:N ratio $[\mathrm{Eq}(3)]$ & $\operatorname{kg} C(\operatorname{kg~N})^{-1}$ \\
\hline$Y_{\mathrm{C}}$ & Yield class [Fig 7] & $\mathrm{m}^{3} \mathrm{ha}^{-1} \mathrm{y}^{-1}$ \\
\hline \multicolumn{3}{|c|}{ Soil sub-model inputs } \\
\hline Symbol & Definition & Values and Units \\
\hline$I_{\text {Caph } \rightarrow \text { surf-li }}, I_{\text {Naph } \rightarrow \text { surf-li }}$ & $\mathrm{C}, \mathrm{N}$ inputs to surface litter pools $[\mathrm{Eq}(126)]$ & $\mathrm{kg} \mathrm{C}, \mathrm{N} \mathrm{m}^{-2} \mathrm{~d}^{-1}$ \\
\hline $\begin{array}{l}I_{\text {Caph } \rightarrow \text { surf-li,cel }} \\
I_{\text {Naph } \rightarrow \text { surf-li,cel }}\end{array}$ & $\begin{array}{l}\mathrm{C}, \mathrm{N} \text { inputs to surface litter cellulose } \mathrm{C}, \mathrm{N} \text { pools [Eqs } \\
(127),(128)]\end{array}$ & $\mathrm{kg} \mathrm{C}, \mathrm{N} \mathrm{m}^{-2} \mathrm{~d}^{-1}$ \\
\hline $\begin{array}{l}I_{\text {Caph } \rightarrow \text { surf-li,lig }} \\
I_{\text {Naph } \rightarrow \text { surf-li,lig }}\end{array}$ & $\begin{array}{l}\text { C, N inputs to surface litter lignin C, N pools [Eqs (127), } \\
(128)]\end{array}$ & $\mathrm{kg} \mathrm{C}, \mathrm{N} \mathrm{m}^{-2} \mathrm{~d}^{-1}$ \\
\hline $\begin{array}{l}I_{\text {Caph } \rightarrow \text { surf-li,met }} \\
I_{\text {Naph } \rightarrow \text { surf-li,met }}\end{array}$ & $\begin{array}{l}\mathrm{C}, \mathrm{N} \text { inputs to surface litter metabolic } \mathrm{C}, \mathrm{N} \text { pools [Eqs } \\
(125),(128)]\end{array}$ & $\mathrm{kg} \mathrm{C}, \mathrm{N} \mathrm{m}^{-2} \mathrm{~d}^{-1}$ \\
\hline \multicolumn{3}{|c|}{ Environmental variables which impact directly on the aphid sub-model } \\
\hline Symbol & Definition & Values and Units \\
\hline$T_{\text {air }}$ & $\begin{array}{l}\text { Air temperature varies diurnally and seasonally, assumed } \\
\text { to be aphid temperature. It affects emigration [Eq }(61)] \text {, } \\
\text { mortality }[\mathrm{Eq}(9)] \text {, fecundity [Eq }(18)] \text {, alate:apterous } \\
\text { ratio in offspring }[\mathrm{Eq}(25)]\end{array}$ & ${ }^{\circ} \mathrm{C}$ \\
\hline
\end{tabular}




\section{A. Tree compartments}

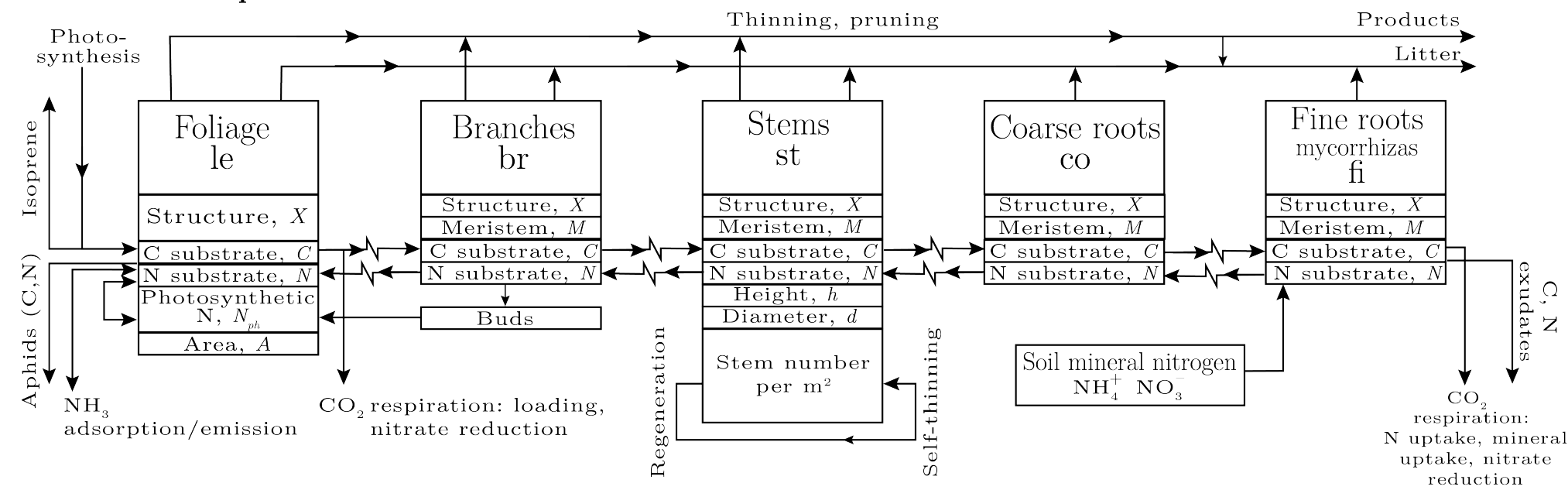

Foliage and fine roots have four age categories for structure and foliage area reduction

B. Processes for a compartment (not foliage, omitting bud synthesis)

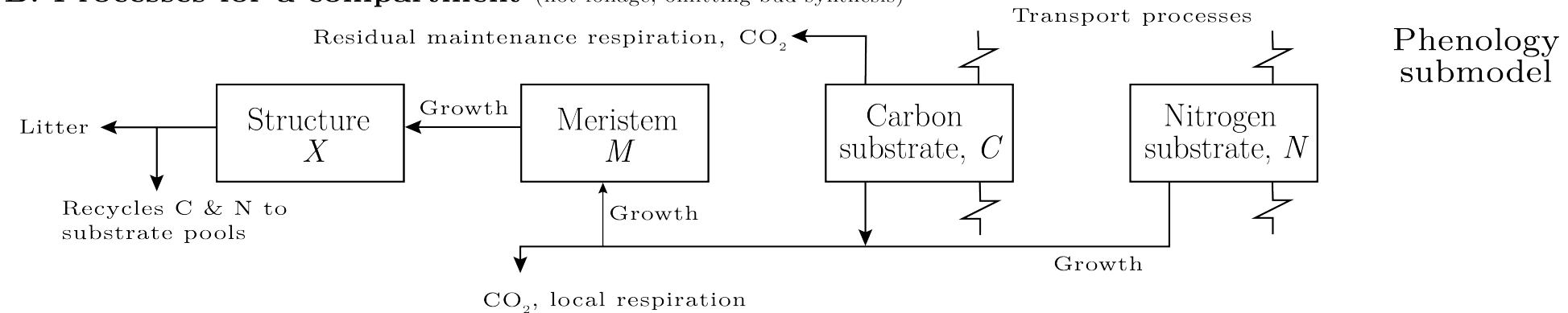

Fig 1. Tree sub-model of the Edinburgh Forest Model (efm). Aphids are connected to the tree sub-model on the left side in A, where

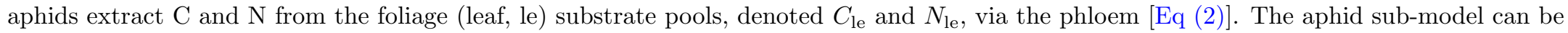




\section{Green spruce aphid submodel}

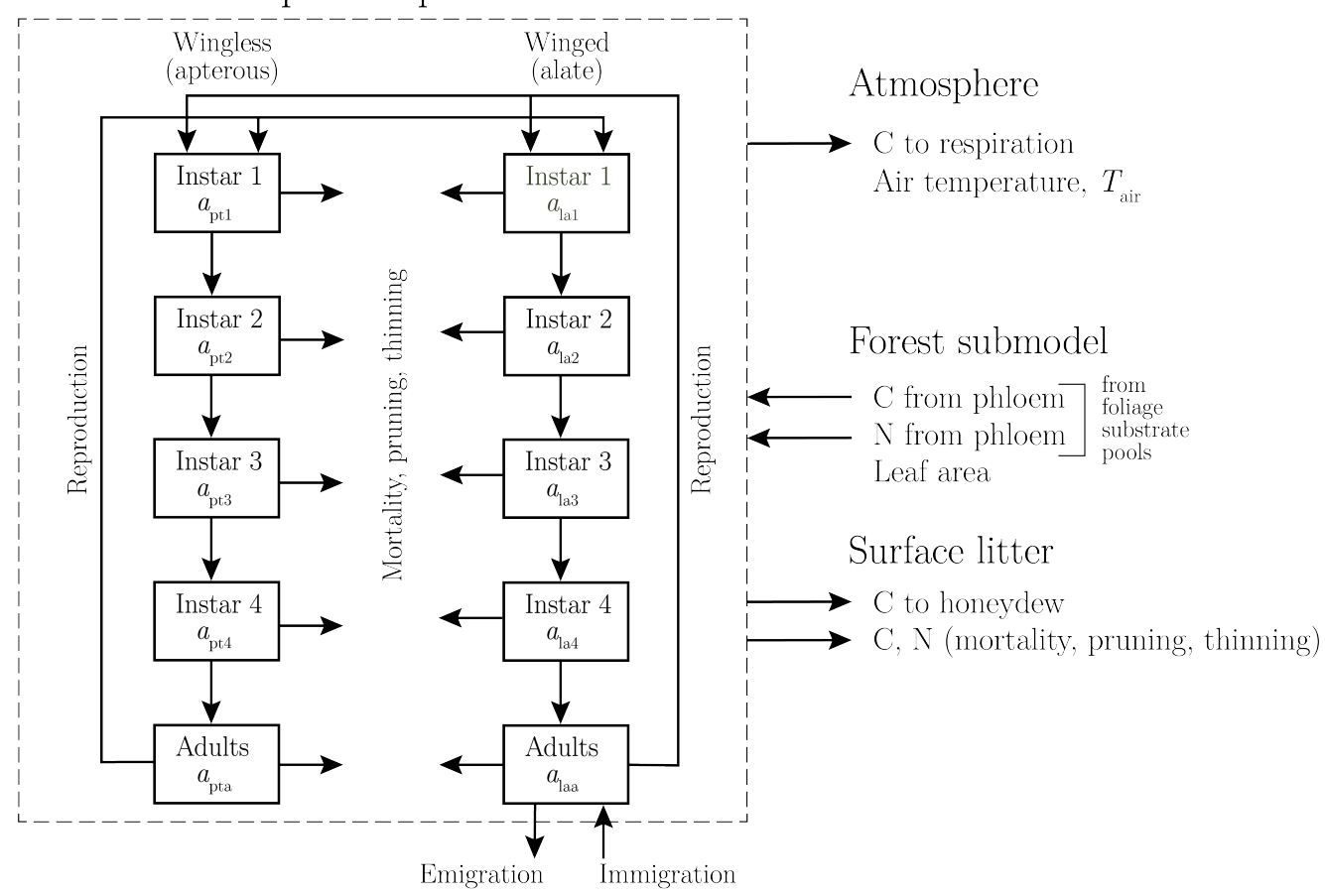

Fig 2. The green spruce aphid sub-model. The ten state variables of the sub-model are shown in the boxes. There are four instars and an adult form for the wingless (apterous) and the winged (alate) aphids. Units for the state variables are number of aphids per stem (Appendix E). The differential equations for the state variables are Eqs (16), (47), (64) and (87). Return to text. 

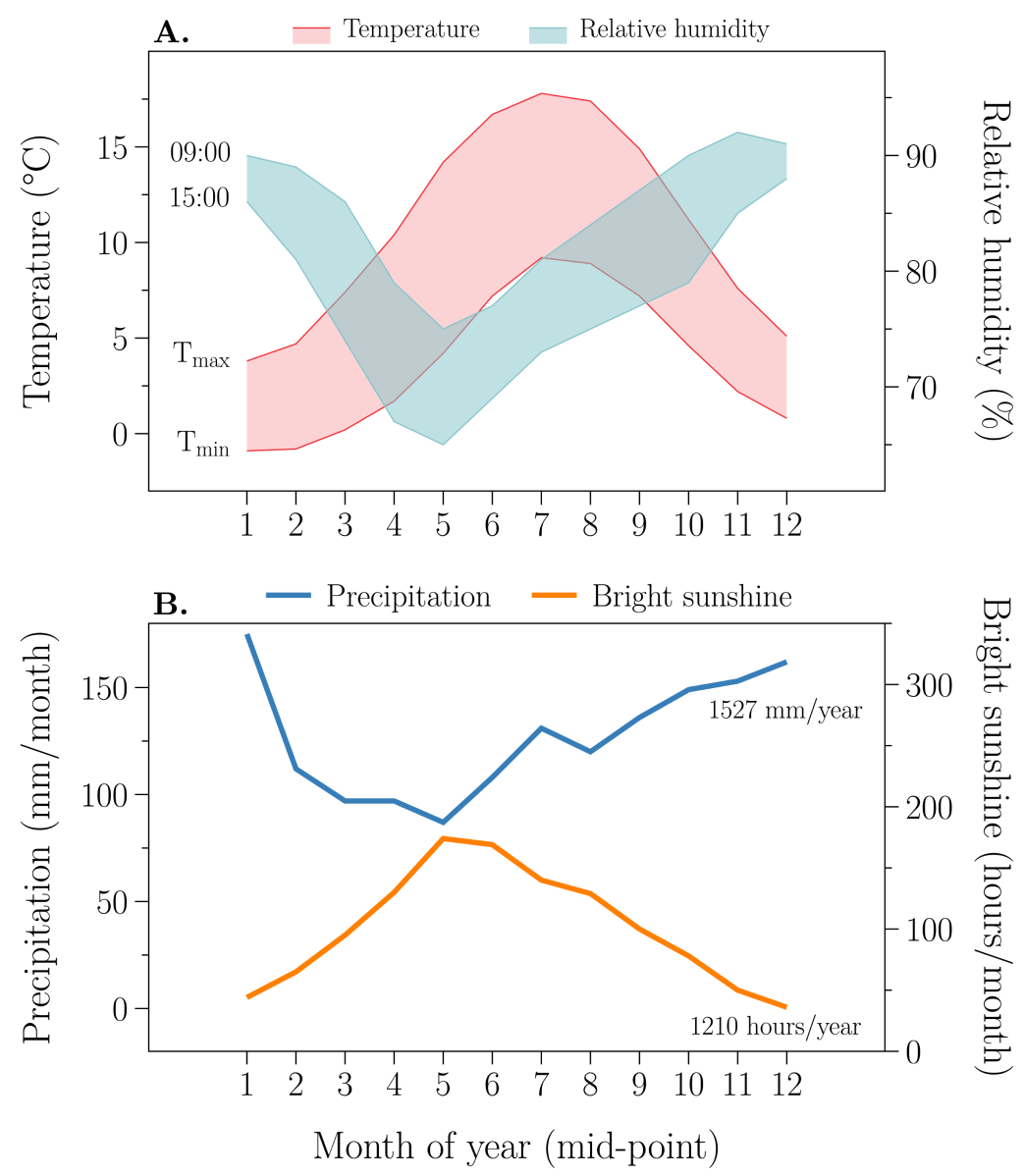

Fig 3. Climate at Eskdalemuir. 30-year monthly means taken from meteorological 1110 tables are drawn. See text for details. Return to text. 

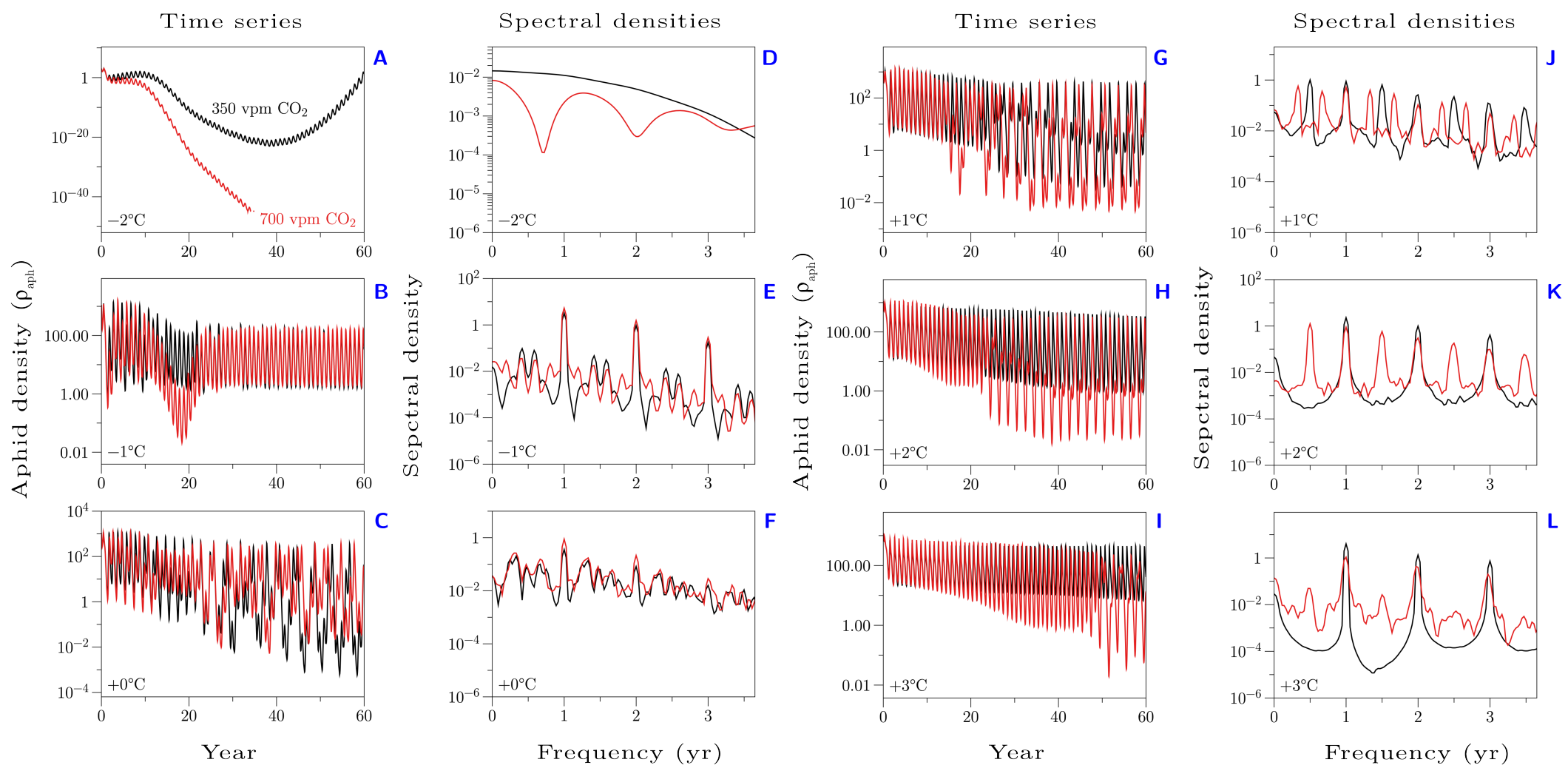

Fig 4. Aphid density dynamics. Shown are the time series of aphid densities $\left(\rho_{\text {aph }}\right.$ ) for incremental increases in temperature from $-2{ }^{\circ} \mathrm{C}$ to ${ }_{1113}$ $+3{ }^{\circ} \mathrm{C} .350 \mathrm{vpm} \mathrm{CO}_{2}$ is shown in black, and $700 \mathrm{vpm} \mathrm{CO}_{2}$ is shown in red. Notice the qualitative differences in population dynamics that emerge as temperture and $\mathrm{CO}_{2}$ change. Next to each time series is the respective spectral density (arbitrary units) calculated from the last 32 years of 1115 each time series; the frequency ( $x$-axis) has been re-scaled to display in years. Return to text. 
bioRxiv preprint doi: https://doi.org/10.1101/2021.05.26.445772; this version posted May 26, 2021. The copyright holder for this preprint (which

was not certified by peer review) is the author/funder, who has granted bioRxiv a license to display the preprint in perpetuity. It is made available under aCC-BY 4.0 International license.
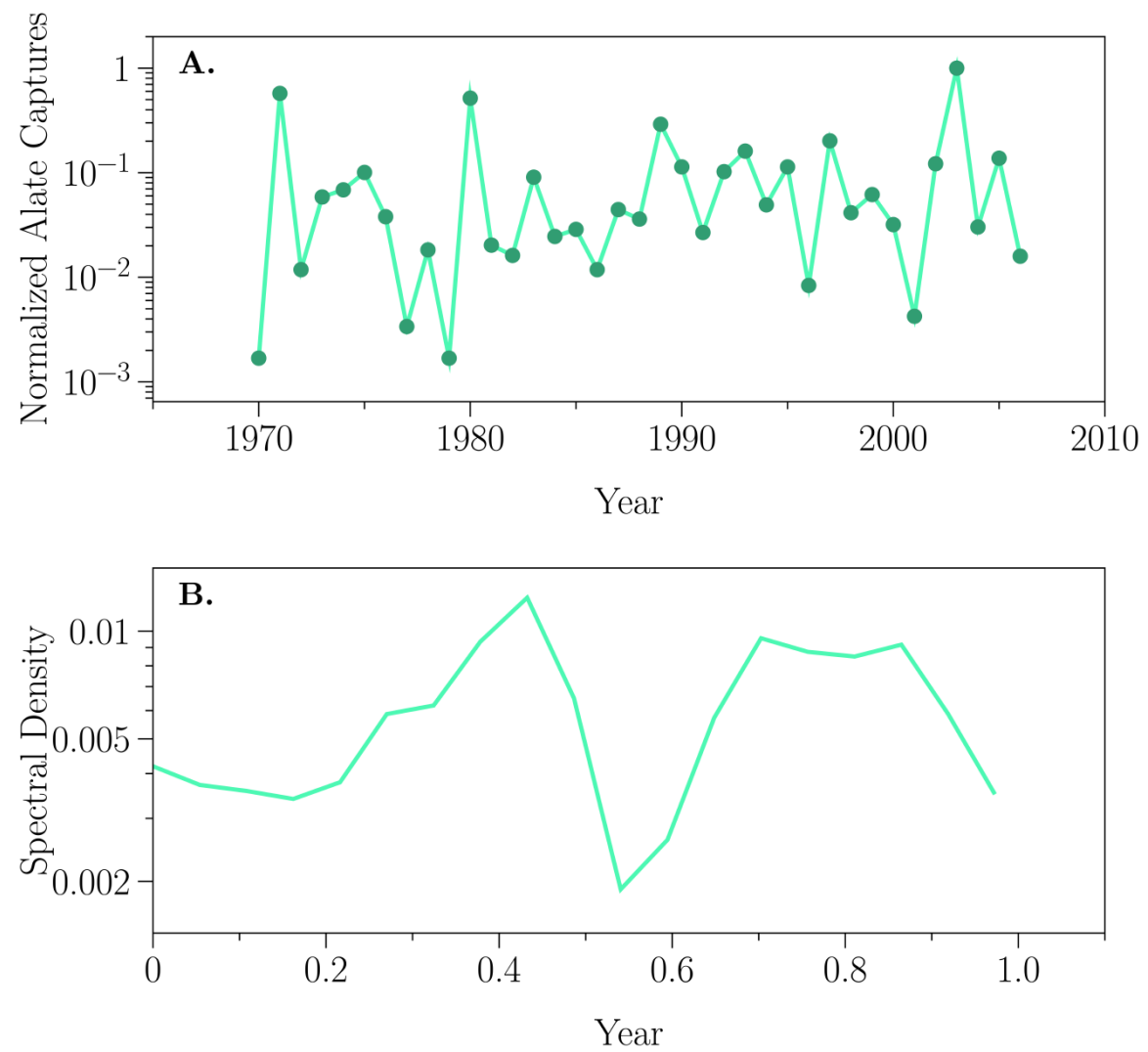

Fig 5. Alate density dynamics. Shown are the time series of alate aphid captures (normalized to the maximum number of captures, see Day et al. [42] for more details) and the associated spectral density function. Return to text. 

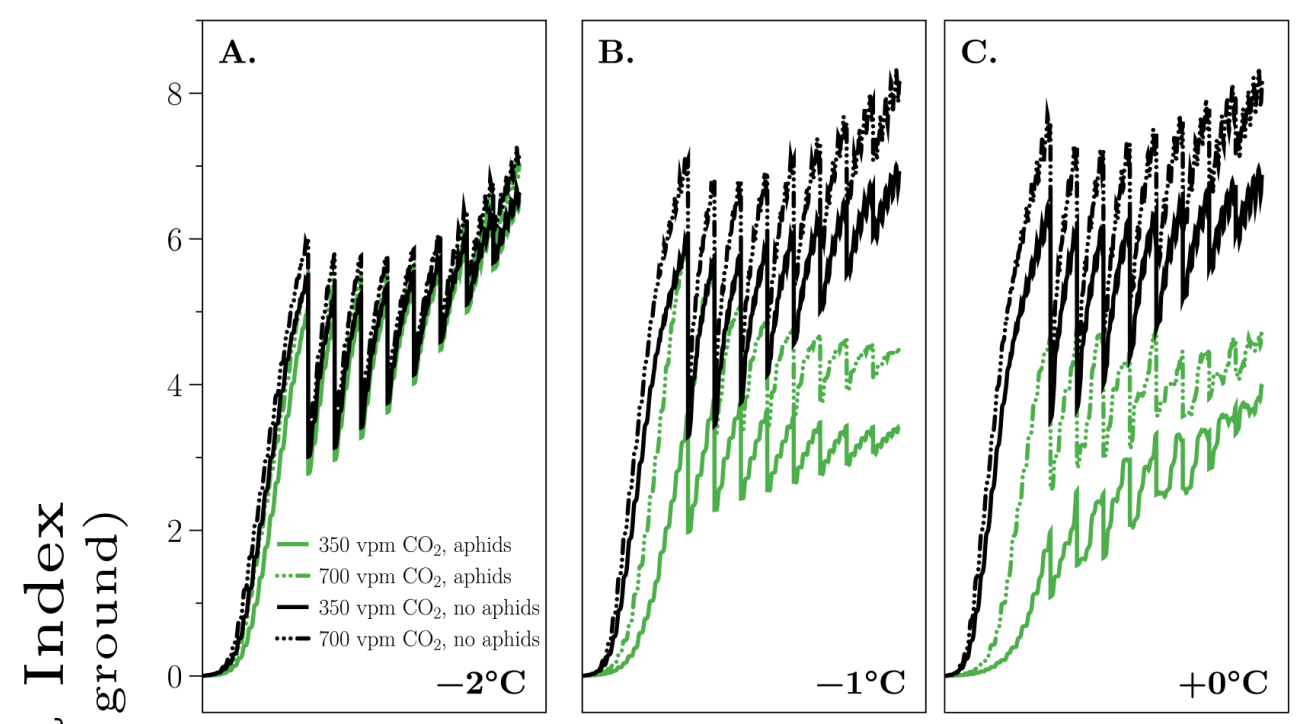

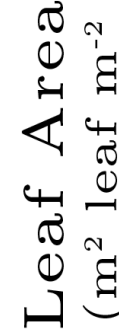

D.

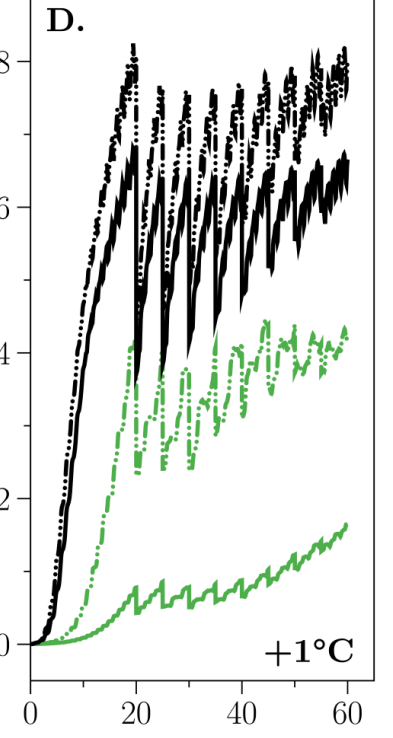

E.

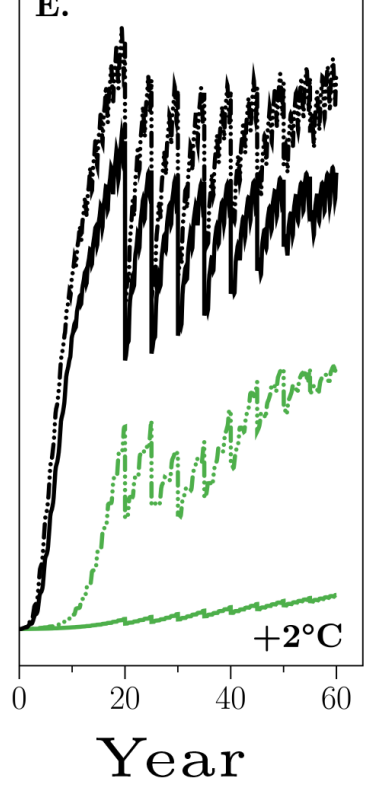

F.

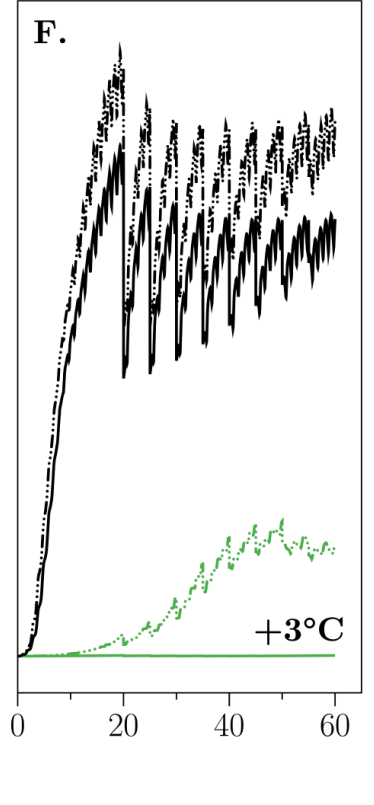

Fig 6. Leaf Area Indices. Shown are the Leaf Area Indices $\left(\mathrm{m}^{2}\right.$ leaf $\mathrm{m}^{-2}$ of ground), ${ }_{1120}$ $\mathrm{Eq}(1)$, for incremental temperature changes at $350 \mathrm{vpm}$ and $700 \mathrm{vpm} \mathrm{CO}_{2}$, with and ${ }_{1121}$ without aphids. The LAI values result from changes in aphid density dynamics, see ${ }_{1122}$ Fig 4. Return to text. 

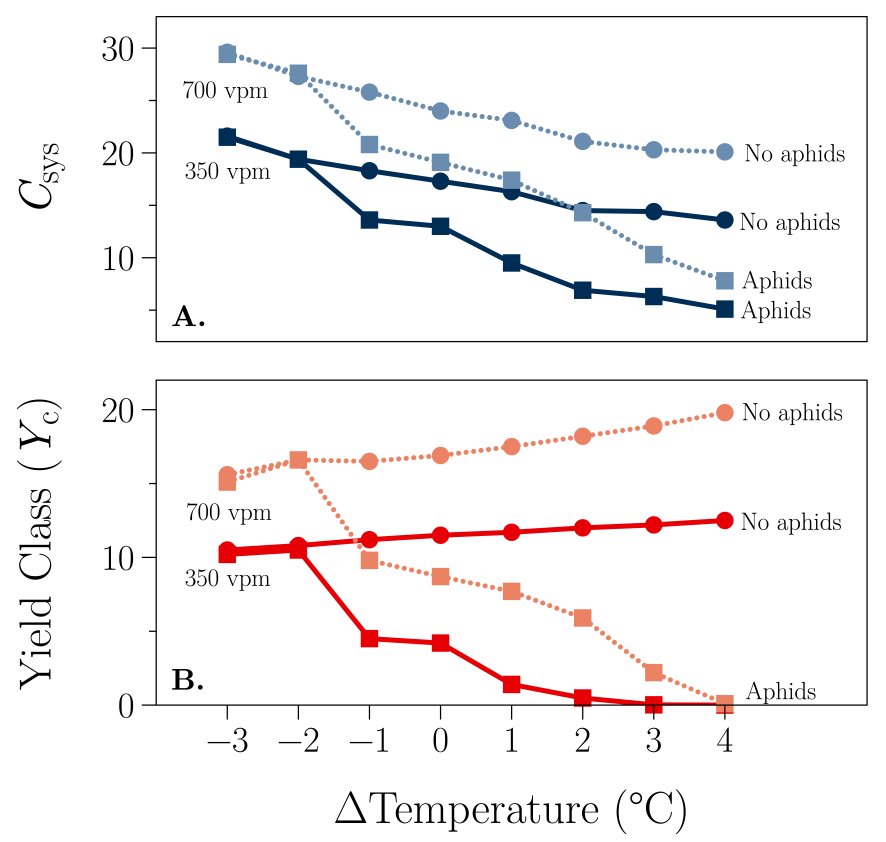

Fig 7. Yield and C-sequestration. $\Delta$ Temperature is the increment in air and soil temperatures applied to the Eskdalemuir environment (Section 4.1, Fig 3). The $\mathrm{CO}_{2}$ concentration is denoted by the shading (dark color: $350 \mathrm{vpm}$, light color: $700 \mathrm{vpm}$ ). The aphid condition is denoted by the symbol ( $\bullet$ : without aphids, $\mathbf{\square}$ : with aphids). $Y_{\mathrm{C}}$ is the yield class $\left(\mathrm{m}^{3} \mathrm{ha}^{-1} \mathrm{y}^{-1}\right)$, defined as the volume $\left(\mathrm{m}^{3}\right)$ of timber harvested at the end of a rotation per hectare averaged over the duration of a rotation of 60 years; $C_{\text {sys }}$ $\left(\mathrm{kg} \mathrm{C} \mathrm{m}^{-2}\right)$ is the total $\mathrm{C}$ in the system at the end of the $60 \mathrm{y}$ rotation. Results are shown for the no-aphid infestation situation (a steady state as applied in Fig 4) and for that when aphids are applied at time zero [Eq (64)]. Return to text. 
bioRxiv preprint doi: https://doi.org/10.1101/2021.05.26.445772; this version posted May 26, 2021. The copyright holder for this preprint (which

was not certified by peer review) is the author/funder, who has granted bioRxiv a license to display the preprint in perpetuity. It is made available under aCC-BY 4.0 International license.

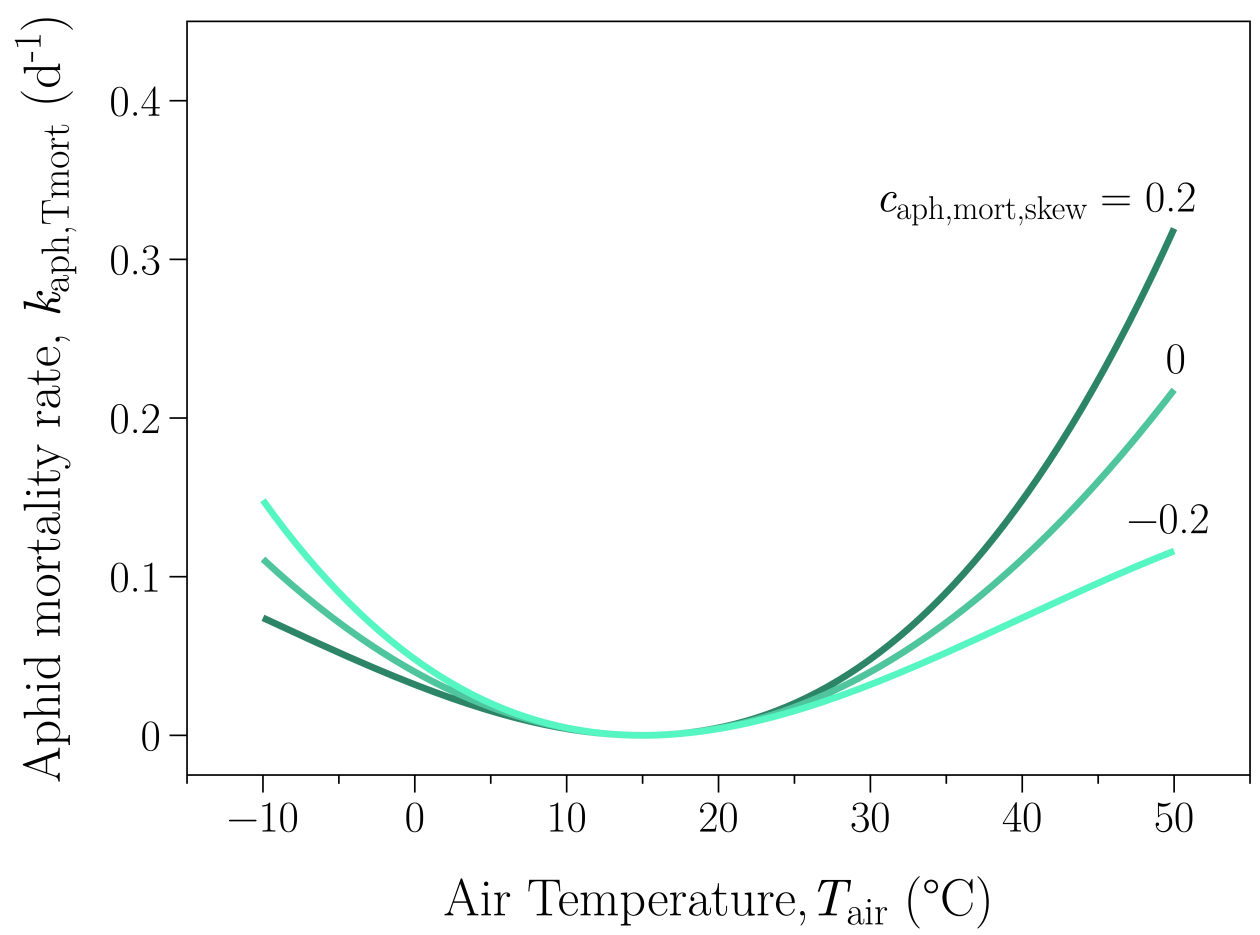

Fig D.1. Aphid mortality rate as affected by temperature. Eq (9) is plotted for three values of the skewness parameter $c_{\text {aph,mort,skew }}$ as given. The default value used in the simulations is 0.2 , shown by the dark line. Other parameters are as in Eq (9). Return to text. 


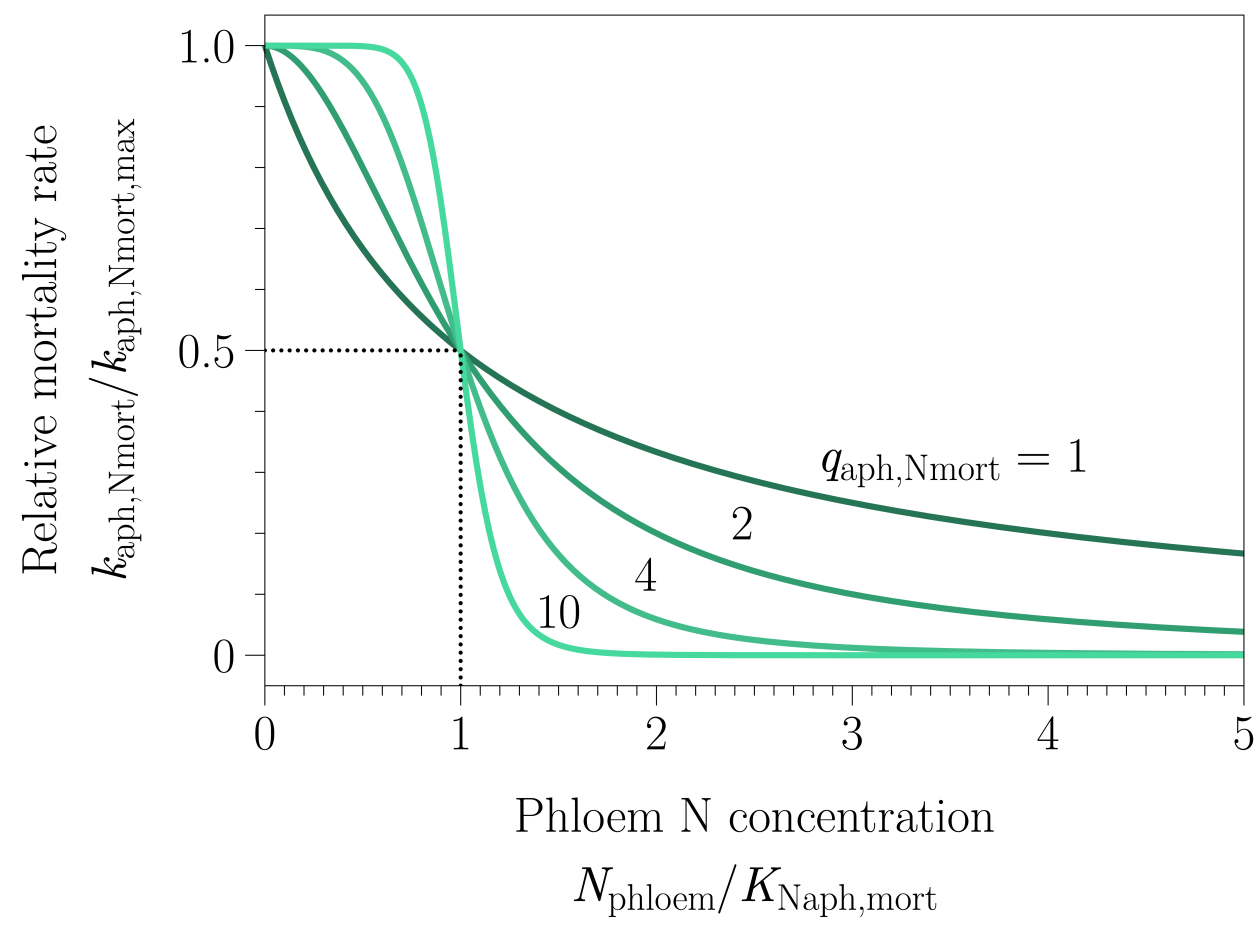

Fig D.2. Nutritional response of aphid mortality. Aphid mortality rate as affected by $\mathrm{N}$ nutrition, in particular, $\mathrm{N}$ concentration in the phloem, $N_{\text {phloem }}$ [Eq (2)]. $\mathrm{Eq}(10)$ is plotted for four values of the steepness parameter, $q_{\mathrm{aph}, \mathrm{Nmort}}$, as given. The default value used in the simulations is $q_{\text {aph,Nmort }}=2$. Return to text. 


\section{Components of mortality response}
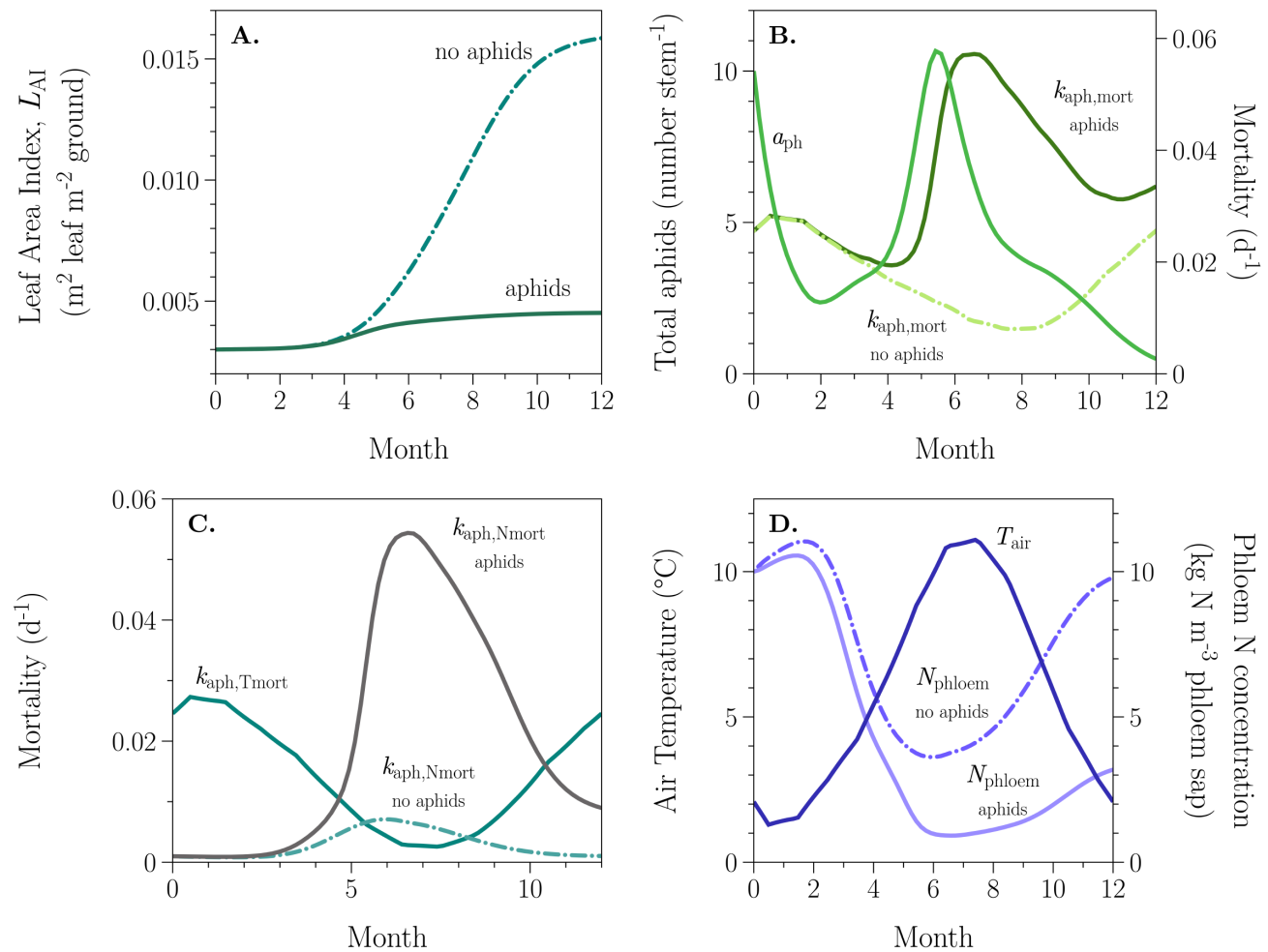

Fig D.3. Aphid mortality. Contributions to aphid mortality are shown over $12 \quad{ }_{1141}$ months without aphids being present (dash-dot lines) and with aphid infection at $t=0$ (solid lines) of 10 adult alates per stem [Eq (64)]. At $t=0 \mathrm{~d}$ the seedling plants have an

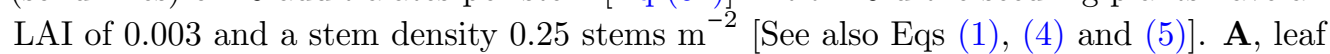
area index, $L_{\mathrm{AI}}[\mathrm{Eq}(1)] . \mathbf{B}$, total aphids, $a_{\mathrm{ph}}[\mathrm{Eq}(4)]$; aphid mortality rate, $k_{\text {aph,mort }}$ [Eq (11)]. C, temperature-dependent mortality, $k_{\text {aph,Tmort }}[\mathrm{Eq}(9)]$; nitrogen-dependent mortality, kaph,Nmort $[\mathrm{Eq}(10)]$. D, Air temperature, $T_{\text {air }}$ (Fig 3), the determinant of temperature-dependent mortality in $\mathbf{C}$; phloem $\mathrm{N}$ [Eq (2)], the determinant of nutrition-dependent mortality in $\mathbf{C}$, phloem $\mathrm{N}$ is decreased by aphid infestation (solid line). Return to text. 


\section{General temperature function, $f(T)$}

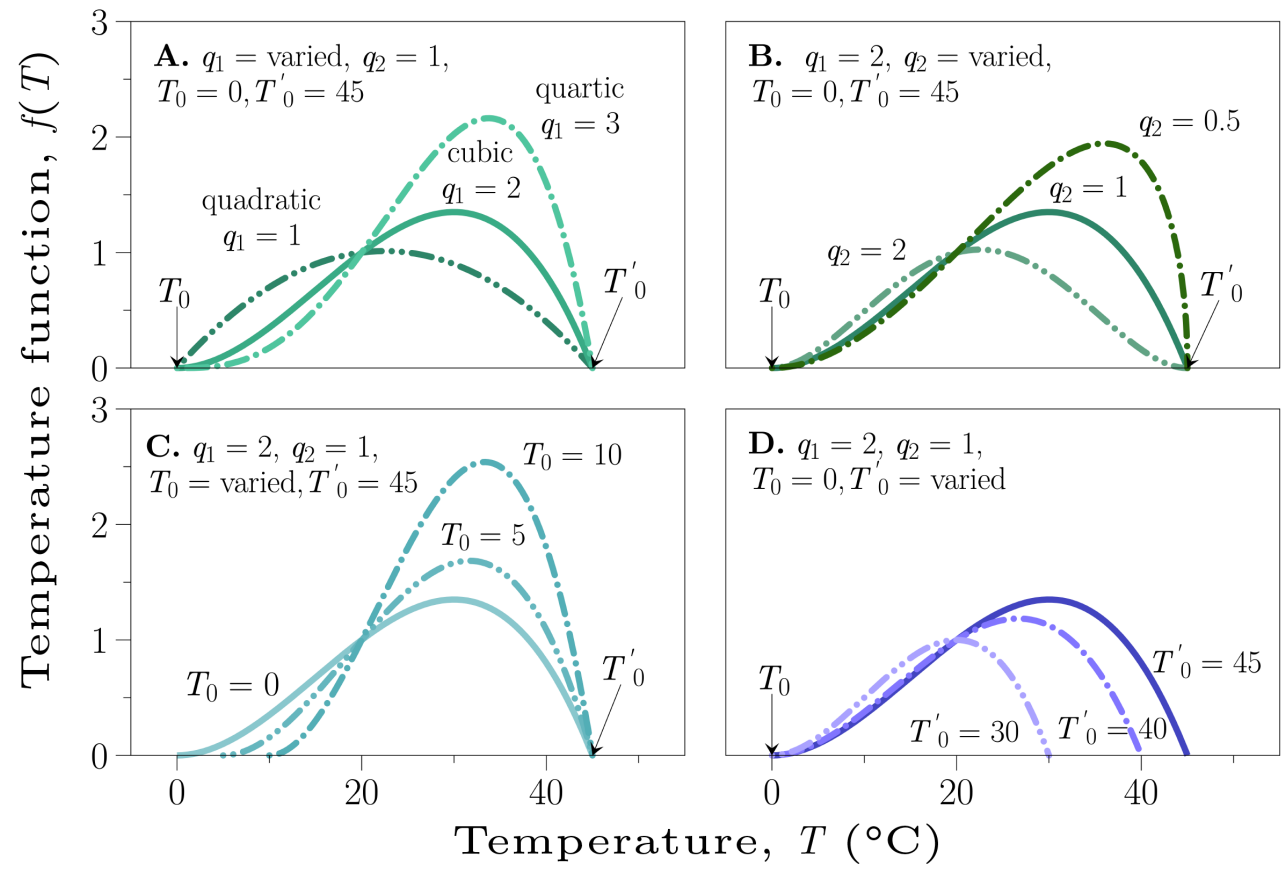

Fig D.4. General biological temperature function.. General biological temperature function, Eq (17), with five parameters: $q_{1}, q_{2}, T_{0}, T_{0}^{\prime}$ and $T_{\text {ref }}$, of which four are varied in the figure. This is applied in the efm and the aphid sub-model for various processes. It is drawn, in $\mathbf{A}$ for three values of parameter $q_{1}$, in $\mathbf{B}$ for three values of $q_{2}$, in $\mathbf{C}$ for three values of $T_{0}$ and in $\mathbf{D}$ for three values of $T_{0}^{\prime}$. Otherwise, the parameters have the values given in Eq (17). Commonly used default values are shown by the continuous heavy lines. Return to text. 


\section{Elements determining fecundity}
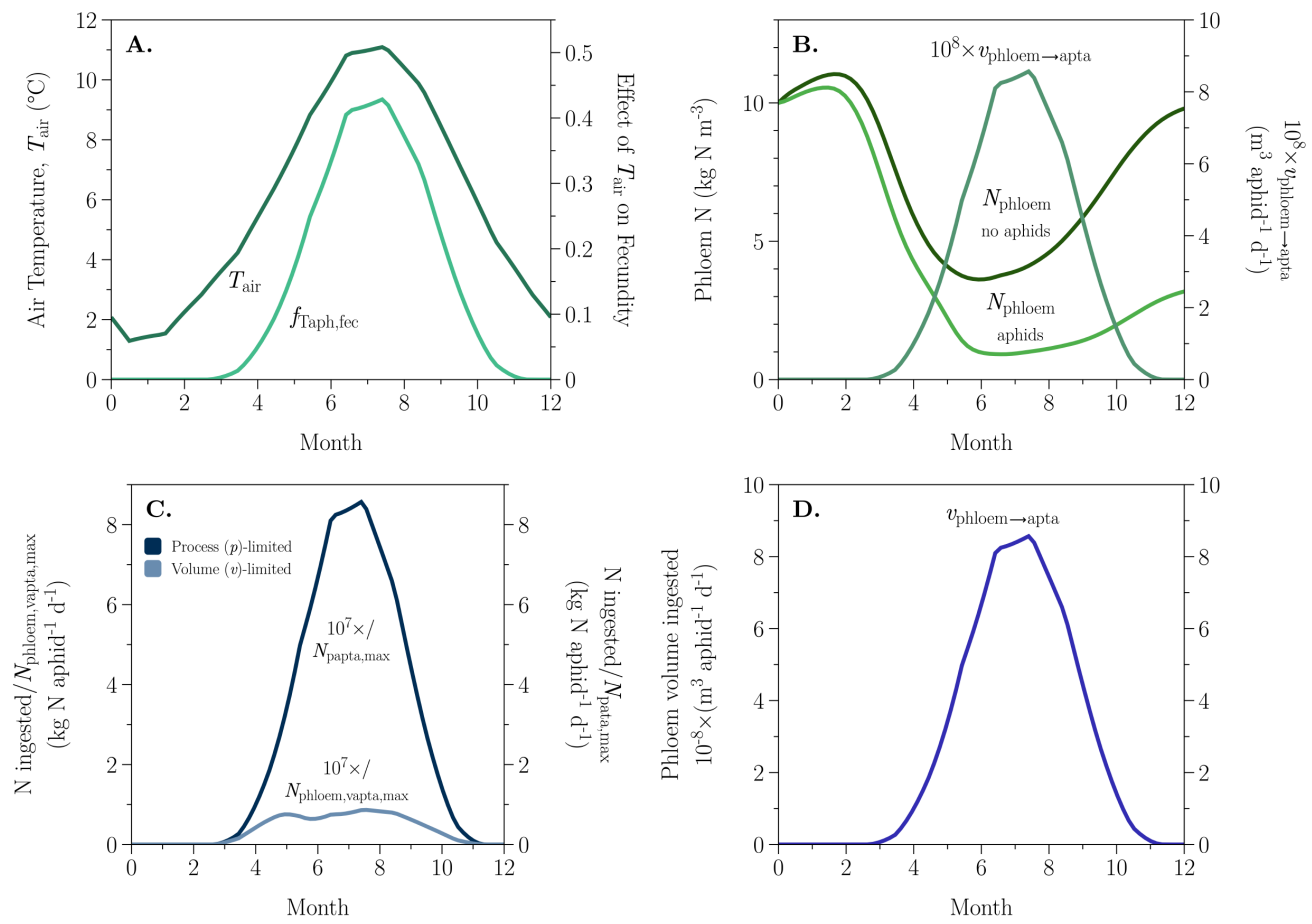

Fig D.5. Elements determining fecundity. Factors contributing to fecundity are shown as they occur in an Eskdalemuir environment (Section 4.1), for the first year of growth of typical spruce plantation (Section 4.2) infected with ten alate adults at time zero $[\mathrm{Eq}(64)]$. A, air temperature, $T_{\text {air }}$, and its effect on fecundity, $f_{\text {Taph,fec }}$ [Eq (18)]. B, phloem N concentration, $N_{\text {phloem }}[\mathrm{Eq}(2)]$ is illustrated without and with aphid infection which lowers $N_{\text {phloem }}$ levels and thereby increases the actual volume of phloem sap ingested, $v_{\text {phloem } \rightarrow \text { apta }}[\mathrm{Eq}(23)]$. C, alternatives for the $\mathrm{N}$ ingested per aphid per day: (i) process-limited $(p) \mathrm{N}$ intake, $I_{\mathrm{Npapta}, \max }[\mathrm{Eq}(21)]$; (ii) phloem-volume-limited $(v) \mathrm{N}$ intake, $I_{\text {Nphloem,vapta,max }}[\mathrm{Eq}(20)]$. D, actual phloem volume ingested per aphid per day, $v_{\text {phloem } \rightarrow \text { apta }}[\mathrm{Eq}(23)]$. Return to text.

1158 1159 1160 1161 1162 1163 1164 1165 1166 1167 


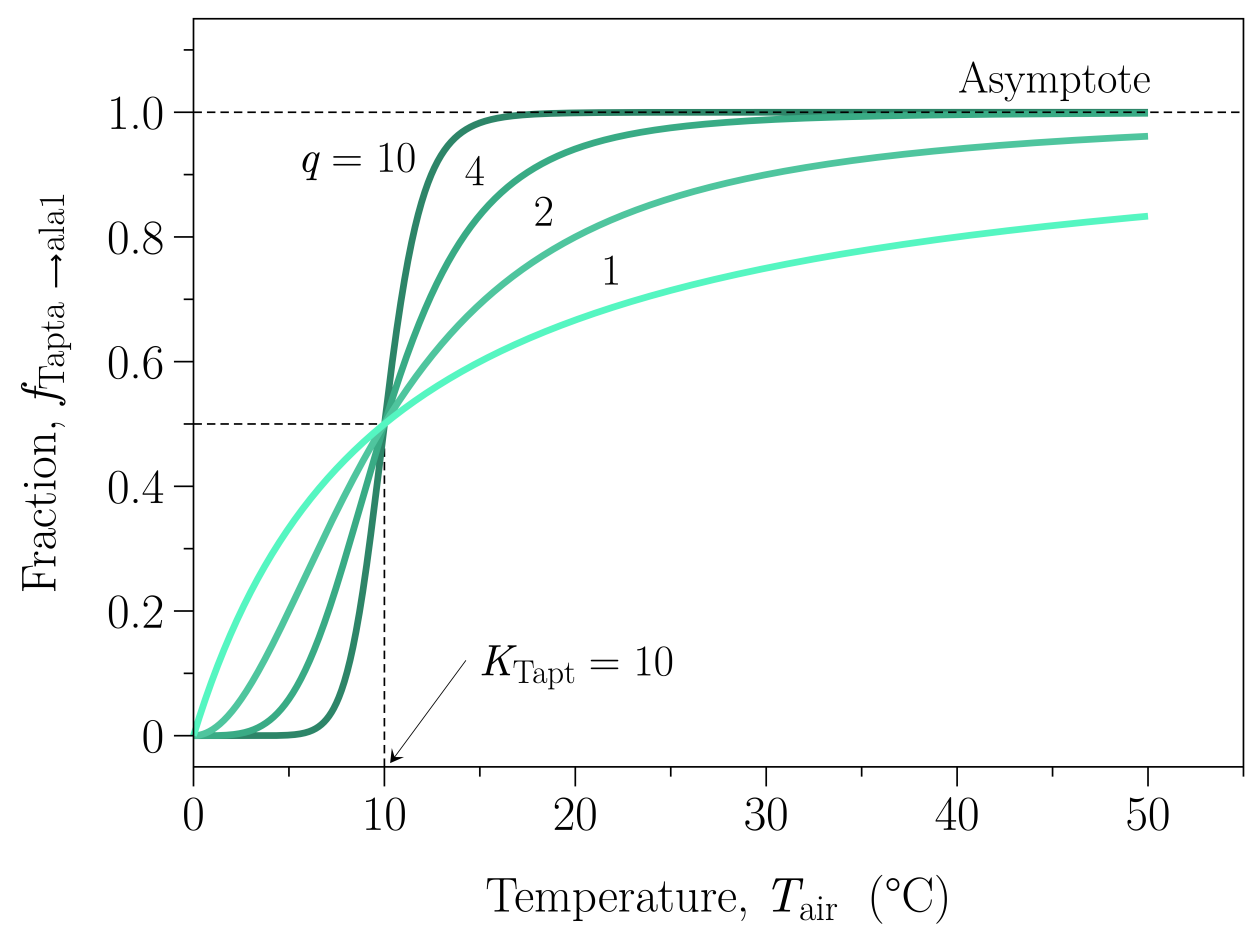

Fig D.6. Alate fraction of apterous offspring as affected by temperature. Eq (25) is drawn for four values of the $q$ parameter. The default value used in the simulations is $q=2$. Return to text. 


\section{Elements contributing to fraction of apterous offspring which are alates}
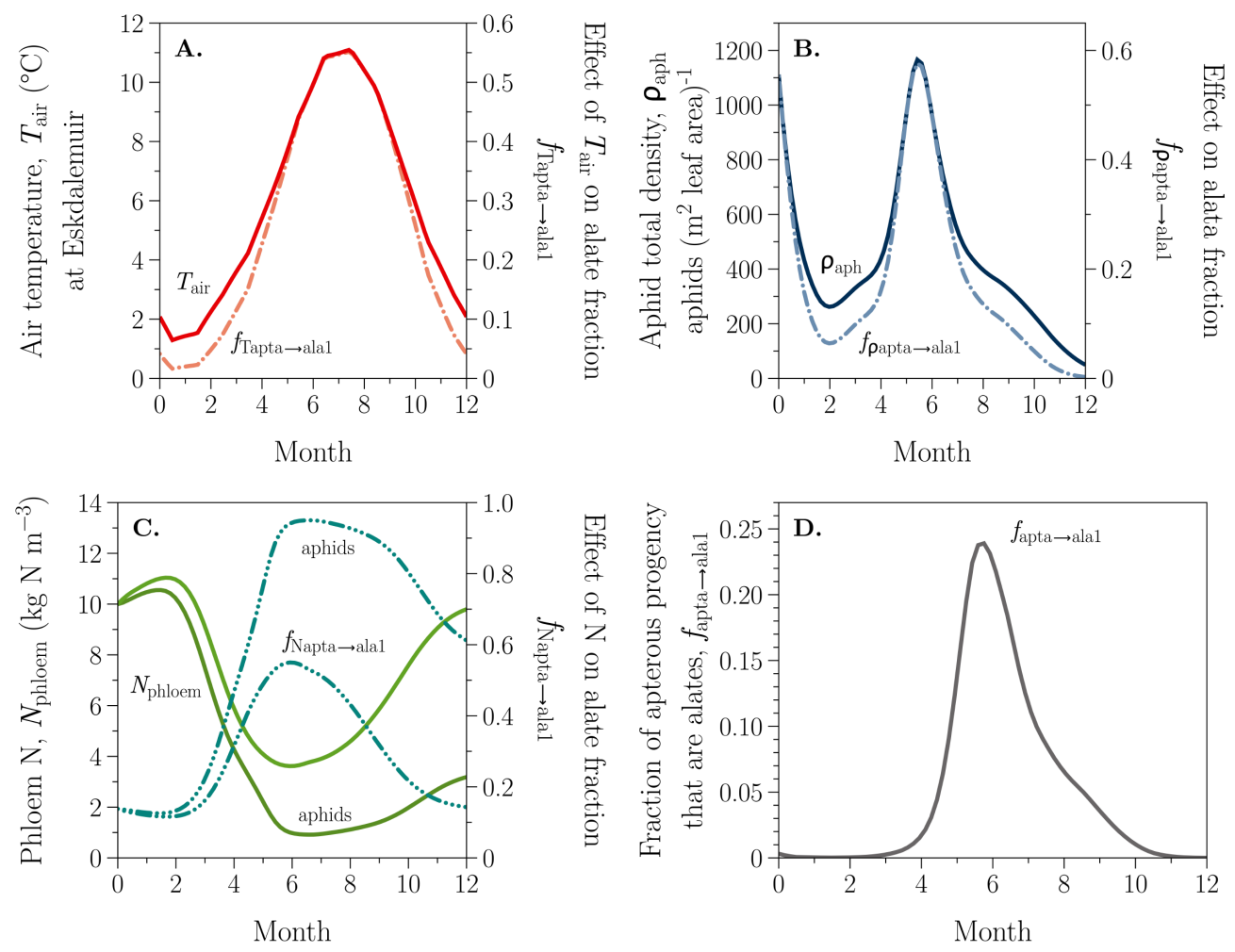

Fig D.7. Elements contributing to the fraction of apterous offspring which are alates.. Illustration of how the three different components contribute to the fraction of apterous offspring which are alates, as in Eq (28). This is for an Eskdalemuir environment (Section 4.1) and the first year of growth of typical spruce plantation (Section 4.2) infected with ten alate adults at time zero [Eq (64)]. A, air temperature, $T_{\text {air }}$, via Eq (25). B, aphid density, $\rho_{\text {aph }}$, via Eq (26). C, phloem N, $N_{\text {phloem }}$, via Eq (27). Here, the introduction of aphids at time zero, depresses $N_{\text {phloem }}$, the lower continuous line, resulting in a higher fraction destined for alates (upper dashed line). D the three factors shown in $\mathbf{A}, \mathbf{B}, \mathbf{C}$ are combined in Eq (28). Return to text.

1171 1172 1173 1174 1175 1176 1177 1178 1179 

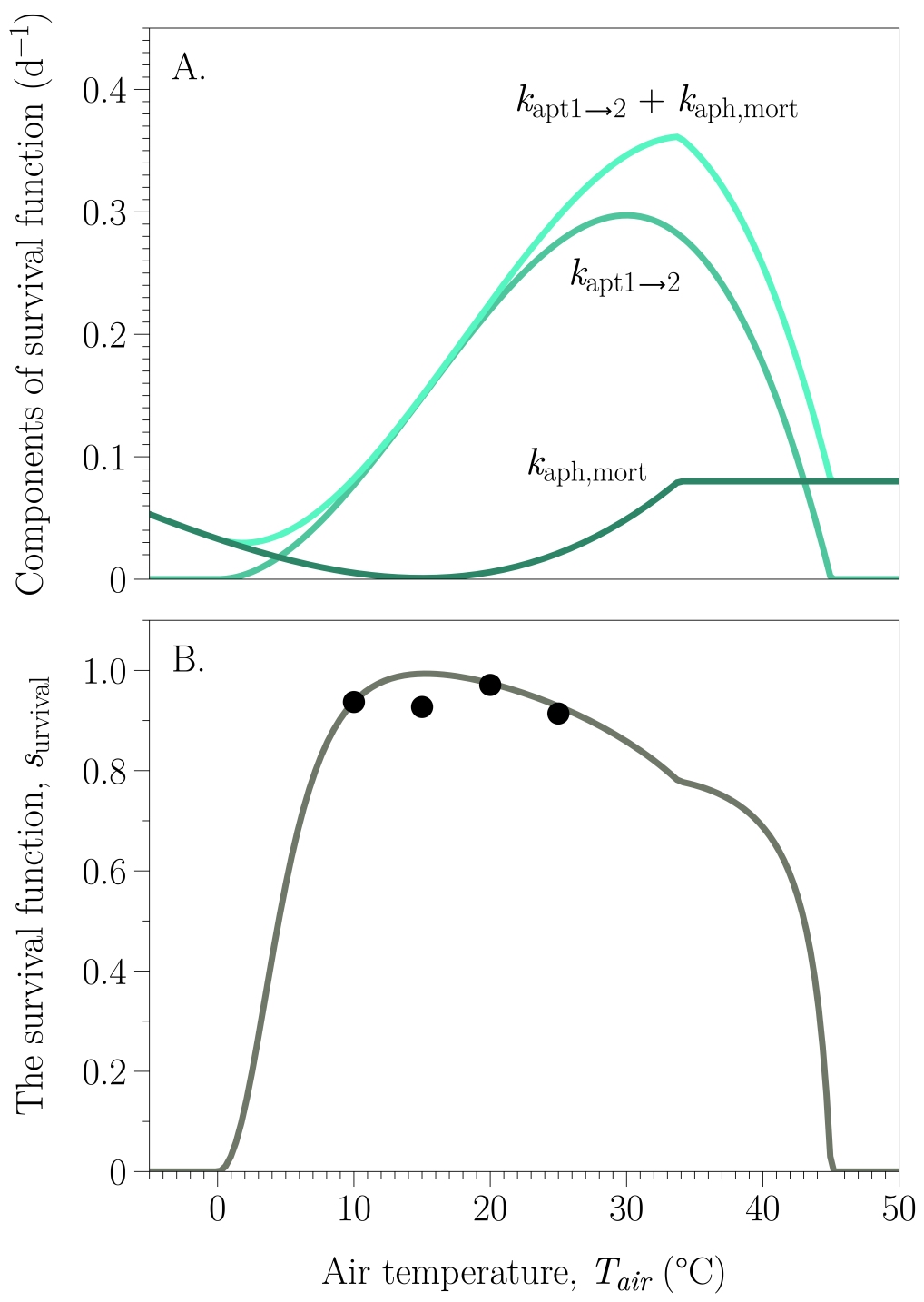

Fig D.8. Survival: effect of temperature. The temperature dependence of the survival function, Eq (40). A, the terms making up the function are shown: $k_{\text {apt } 1 \rightarrow 2}$ is the specific rate of transfer of aphids from the 1st instar apterous compartment to the second [Fig 2, Eq (38)]; $k_{\text {aph,mort }}[\mathrm{Eq}(9)$, Fig D.3A] is the specific aphid mortality rate. B, the asymptotic survival function $s_{\text {urvival }}(t \rightarrow \infty)$ [Eq (40)]. The four points shown are from Duffy et al. (figure 3 in [63]), whose data are from Dean [91]. Return to text. 


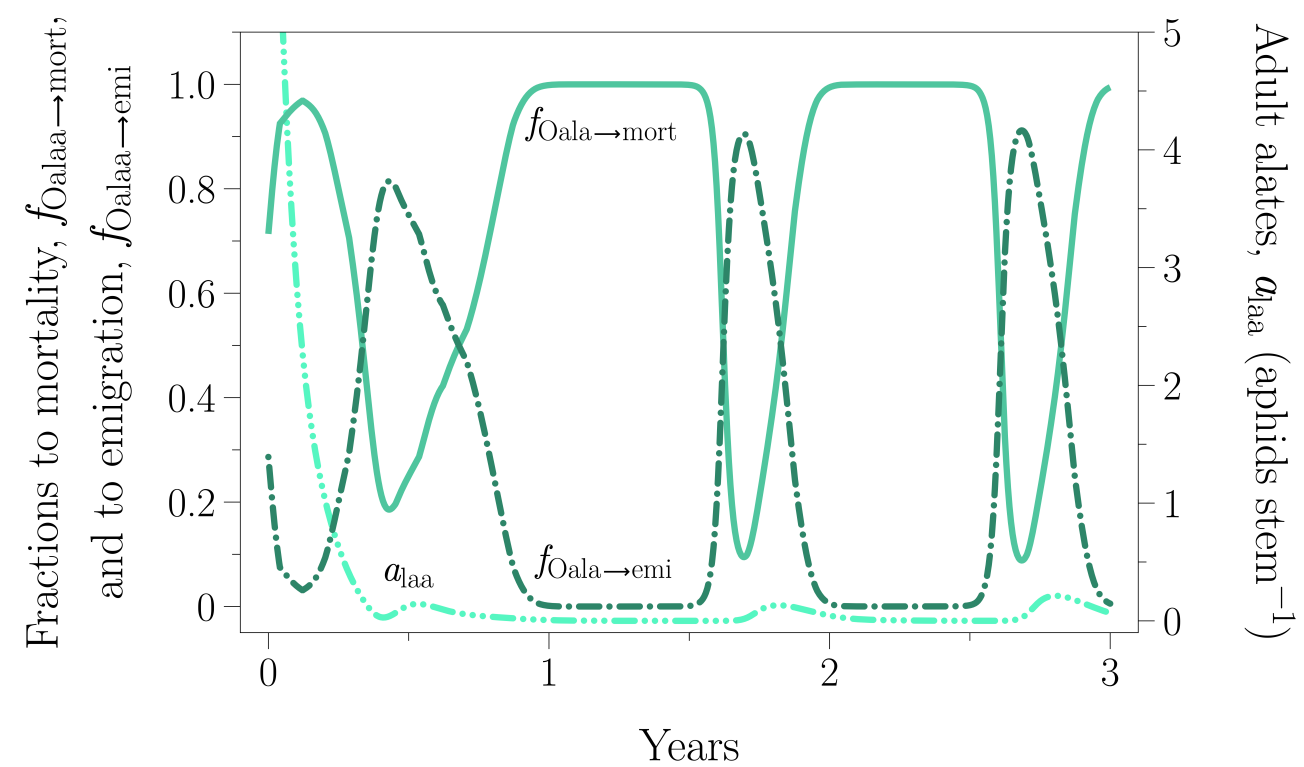

Fig D.9. Fractional output fluxes. Fractional output fluxes of alate adults to mortality, $f_{\text {Oalaa } \rightarrow \text { mort }}$ (solid line) and to emigration, $f_{\text {Oalaa } \rightarrow \text { emi }}[\mathrm{Eq}(99)]$ (dashed-dot) over three years post-infection [Eq (64)] at time $t=0$ for a plantation in a northern Britain environment (Section 4.1). The state variable for alate adults $a_{\text {laa }}$ (Fig 2) is shown by the dashed-dot-dot-dot line [Eq (64)] with reference to the right side ordinate; initial value is 10 and is therefore not shown. Return to text. 